\title{
Methane to Methanol through Heterogeneous Catalysis and Plasma Catalysis
}

\author{
Shangkun Li ${ }^{1,2,+}$, Rizwan Ahmed ${ }^{1,+}$, Yanhui $\mathrm{Yi}^{1,2, * \mathbb{D}}$ and Annemie Bogaerts ${ }^{2}$ (D) \\ 1 State Key Laboratory of Fine Chemicals, School of Chemical Engineering, Dalian University of Technology, \\ Dalian 116024, China; Shangkun.Li@uantwerpen.be (S.L.); naichrizwan189@mail.dlut.edu.cn (R.A.) \\ 2 Research Group PLASMANT, Department of Chemistry, University of Antwerp, Universiteitsplein 1, \\ BE-2610 Wilrijk-Antwerp, Belgium; annemie.bogaerts@uantwerpen.be \\ * Correspondence: yiyanhui@dlut.edu.cn; Tel.: +86-411-8498-6120 \\ + These authors contributed equally.
}

Citation: Li, S.; Ahmed, R.; Yi, Y.; Bogaerts, A. Methane to Methanol through Heterogeneous Catalysis and Plasma Catalysis. Catalysts 2021, 11, 590. https://doi.org/10.3390/ catal11050590

Academic Editor: Leon Lefferts

Received: 12 April 2021

Accepted: 29 April 2021

Published: 1 May 2021

Publisher's Note: MDPI stays neutral with regard to jurisdictional claims in published maps and institutional affiliations.

Copyright: (c) 2021 by the authors. Licensee MDPI, Basel, Switzerland. This article is an open access article distributed under the terms and conditions of the Creative Commons Attribution (CC BY) license (https:// creativecommons.org/licenses/by/ $4.0 /)$.
Abstract: Direct oxidation of methane to methanol (DOMTM) is attractive for the increasing industrial demand of feedstock. In this review, the latest advances in heterogeneous catalysis and plasma catalysis for DOMTM are summarized, with the aim to pinpoint the differences between both, and to provide some insights into their reaction mechanisms, as well as the implications for future development of highly selective catalysts for DOMTM.

Keywords: methane conversion; direct oxidation; methanol production; heterogeneous catalysis; plasma catalysis

\section{Introduction}

Methane $\left(\mathrm{CH}_{4}\right)$, as one of the most important molecules in $\mathrm{C} 1$ chemistry, is widely present in natural gas, shale gas, coalbed gas, combustible ice, etc. Noticeably, natural gas, which consists of approximately $70 \%$ to $90 \% \mathrm{CH}_{4}$, will be part of the energy system for decades [1]. Unfortunately, most of these $\mathrm{CH}_{4}$ reserves are located in remote areas, indicating the need of transportation for utilization of $\mathrm{CH}_{4}[1,2]$. However, due to a very low boiling point $\left(-161.6^{\circ} \mathrm{C}\right.$ at a pressure of $\left.1 \mathrm{~atm}\right)$ and high flammability, compression of $\mathrm{CH}_{4}$ (gas) into $\mathrm{CH}_{4}$ (liquid) for transportation requires huge amounts of energy, making it economically infeasible [3]. In addition, another important issue is the rising global emission of $\mathrm{CH}_{4}$, mainly as by-product of oil production, and its global warming potential is ca. 30 times that of $\mathrm{CO}_{2}$ [1]. The International Energy Outlook 2019 (IEO2019) estimated that 140 billion cubic meters $(\mathrm{bcm})$ were flared and $60 \mathrm{bcm}$ released into the atmosphere in 2018, more than the annual LNG (Liquefied Natural Gas) imports of Japan and China combined. This enormous source of emissions accounts for $40 \%$ of the total indirect emissions from global oil supply. Therefore, the conversion of $\mathrm{CH}_{4}$ to value-added chemicals has attracted intensive interests from both academic and industrial communities.

In general, as shown in Figure 1, the conversion of $\mathrm{CH}_{4}$ into value-added chemicals can be classified into indirect and direct routes [4]. As implemented in industry, indirect routes are, actually, initiated through a steam reforming (SR) and/or auto-thermal reforming (ATR) process to produce syngas (mixture of $\mathrm{CO}$ and $\mathrm{H}_{2}$ ), and then a variety of products such as olefins, gasoline, and diesel, as well as oxygenates, can be obtained using the well-established technology of Fischer-Tropsch synthesis (FTS) promoted by Fe-based or Co-based catalysts [5,6]. Alternatively, using Cu-Zn-Al-based catalysts, syngas can also be converted into methanol $\left(\mathrm{CH}_{3} \mathrm{OH}\right)$, which has been used as feedstock to produce light olefins, gasoline and aromatics through industrial technologies of methanol-to-olefins (MTO), methanol-to-gasoline (MTG) and methanol-to-aromatics (MTA) conversion, respectively [6]. Although the above indirect routes are carried out in industry to produce value-added chemicals from $\mathrm{CH}_{4}$, the syngas production by SR and ATR is energy-intensive and costly, motivating researchers to develop direct routes (not syngas-based) [7]. 


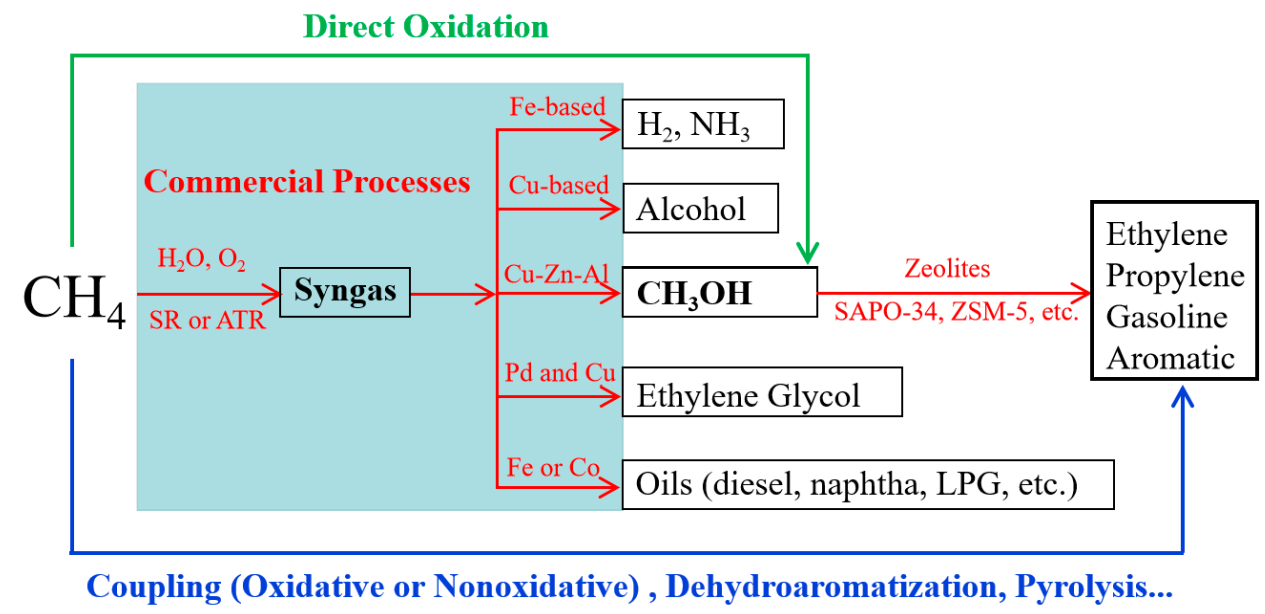

Figure 1. Significant pathways for value-added utilization of $\mathrm{CH}_{4}$. Commercial (indirect) pathways through syngas are indicated in red. Direct routes to olefins, gasoline or aromatics, by various processes, are in blue, while the direct oxidation to $\mathrm{CH}_{3} \mathrm{OH}$ is in green.

Direct routes (Figure 1), including $\mathrm{CH}_{4}$ dehydroaromatization, $\mathrm{CH}_{4}$ coupling to hydrocarbons (both oxidative and non-oxidative coupling), $\mathrm{CH}_{4}$ pyrolysis (high temperature pyrolysis and catalytic pyrolysis) and direct oxidation of $\mathrm{CH}_{4}$ to methanol/formaldehyde, have also been developed and are still being improved [2-8]. However, $\mathrm{CH}_{4}$, a molecule with tetrahedral geometry and four equivalent $\mathrm{C}-\mathrm{H}$ bonds, is inert and difficult to activate and convert. The absence of a dipole moment and a rather small polarizability $\left(2.84 \times 10^{-40} \mathrm{C}^{2} \cdot \mathrm{m}^{2} \cdot \mathrm{J}^{-1}\right)$ imply that $\mathrm{CH}_{4}$ needs a relatively high local electric field to be polarized and to allow electrophilic or nucleophilic attack [2]. $\mathrm{CH}_{4}$ exhibits the highest $\mathrm{C}-\mathrm{H}$ bond strength among all alkanes, with the first bond dissociation energy (BDE) of $493.3 \mathrm{~kJ} \mathrm{~mol}^{-1}(5.1 \mathrm{eV})$, meaning that $\mathrm{CH}_{4}$ is the least reactive alkane [2]. Therefore, most of the direct routes must be operated at ultra-high temperature (973 1223 K), except for direct oxidation to methanol/formaldehyde, which can be realized at relatively low temperature $(300 \sim 700 \mathrm{~K})$, indicating low cost and high feasibility in industry [2,3]. For that reason, direct oxidation has attracted more attention, and in this review, we mainly focus on recent progress of direct oxidation of methane to methanol (DOMTM).

$$
\mathrm{CH}_{4}+0.5 \mathrm{O}_{2} \rightarrow \mathrm{CH}_{3} \mathrm{OH} \quad \Delta \mathrm{H}(298 \mathrm{~K})=-126.4 \mathrm{~kJ} \cdot \mathrm{mol}^{-1}
$$

DOMTM by $\mathrm{O}_{2}$ (1) has been considered as a dream reaction in chemical industry and a holy grail in catalytic chemistry $[9,10]$, and it has attracted intensive interests from both academic and industrial communities for more than 100 years. DOMTM has been studied by homogeneous catalysis, in which noble metals ( $\mathrm{Pt}$ and $\mathrm{Pd}$ ) are typically used as the central atoms of the complex catalysts, and the reaction is usually carried out in strong acid media (sulfuric and trifluoroacetic acid) [11-13]. Alternatively, DOMTM can also be realized by heterogeneous catalysis. In the 1980s, a Mo-based catalyst was developed for $\mathrm{CH}_{4}$ oxidation. The $\mathrm{Mo}=\mathrm{O}$ species was considered to be the active site for the oxidation of $\mathrm{CH}_{4}$ to $\mathrm{CH}_{3} \mathrm{OH}$, and at that time, Mo was considered to be the most active metal catalyst for this reaction [14,15]. However, the biggest drawback of a Mo-based catalyst is that Mo can be easily lost at high temperature through volatilization, which was not conducive for industrial application [16]. Compared with a Mo-based catalyst, a V-based catalyst is more stable, but the $\mathrm{CH}_{4}$ conversion was too low (less than $10 \%$ ) $[17,18]$. At the beginning of this century, inspired by the active sites of double iron and double copper in methane monooxygenase, Fe-based and Cu-based zeolite catalysts have been used in DOMTM [19-22], as well as supported noble metals, such as Au, Pd and Rh [23,24]. Detail information for the developing process of DOMTM can be obtained in the review paper by Bokhoven [3]. 
Although many studies about DOMTM have been reported, it has to overcome two challenges, caused by thermodynamics and kinetics, respectively $[3,9]$. The first is how to improve the $\mathrm{CH}_{3} \mathrm{OH}$ selectivity. Thermodynamically, $\mathrm{CH}_{3} \mathrm{OH}$ is not the favorable product, as $\mathrm{CO}$ and $\mathrm{CO}_{2}$ are more stable than $\mathrm{CH}_{3} \mathrm{OH}$. Specifically, as shown in Figure 2A, a low temperature $(<890 \mathrm{~K})$ favors the production of $\mathrm{CO}_{2}$ and $\mathrm{H}_{2} \mathrm{O}$, while a high temperature $\left(>890 \mathrm{~K}\right.$ ) favors $\mathrm{CO}$ and $\mathrm{H}_{2}$. In other words, due to the higher reactivity of $\mathrm{CH}_{3} \mathrm{OH}$ than the feedstock $\mathrm{CH}_{4}$, the catalytic sites, capable of oxidizing $\mathrm{CH}_{4}$ into $\mathrm{CH}_{3} \mathrm{OH}$, can also further oxidize $\mathrm{CH}_{3} \mathrm{OH}$ into $\mathrm{CO}$ or $\mathrm{CO}_{2}$ before $\mathrm{CH}_{3} \mathrm{OH}$ desorbs from the catalyst surface. Figure 2B indeed illustrates that $\mathrm{CH}_{3} \mathrm{OH}$ and other oxygenates and hydrocarbons are only formed with much lower selectivity.
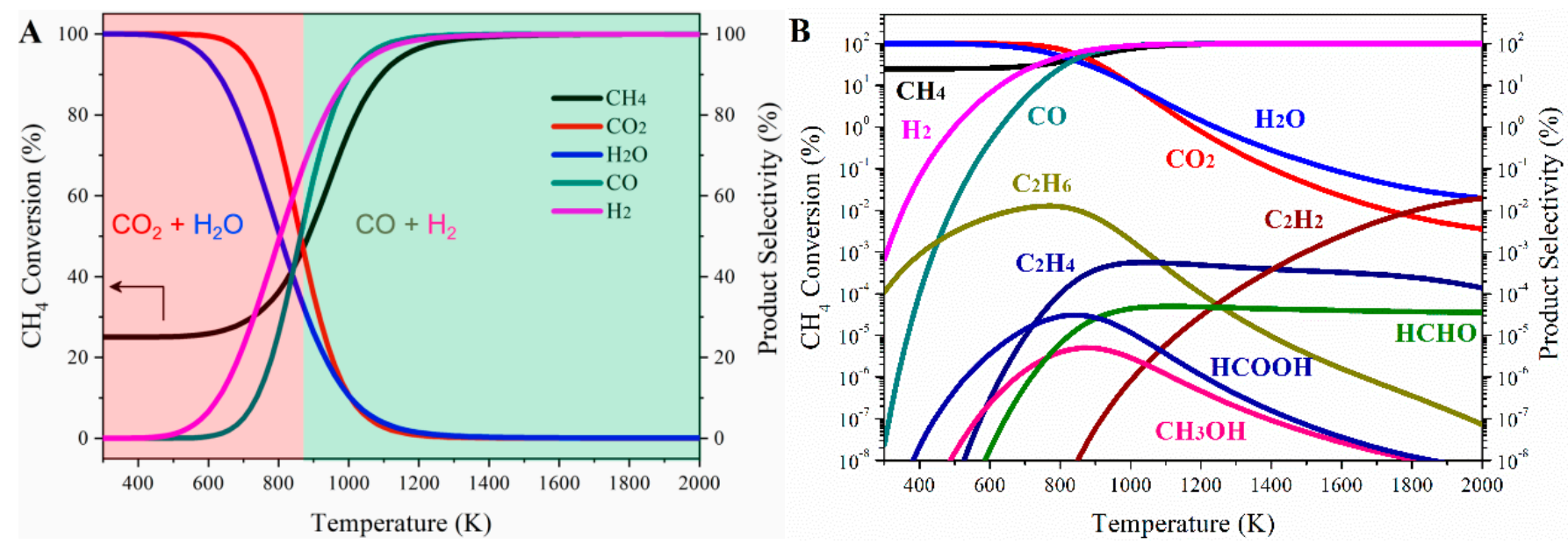

Figure 2. (A) Thermodynamic equilibrium of $\mathrm{CH}_{4}$ conversion upon oxidation by $\mathrm{O}_{2}$ (left axis), and product selectivity (right axis), as a function of reaction temperature at atmospheric pressure (mole ratio: $\mathrm{CH}_{4} / \mathrm{O}_{2}=2 / 1$ ). (B) Product selectivity in logarithmic scale, illustrating the products with lower thermodynamic equilibrium selectivity, including $\mathrm{CH}_{3} \mathrm{OH}$.

The second challenge is how to reduce the kinetic energy barrier (Ea) of DOMTM by $\mathrm{O}_{2}$ at ambient conditions. The Ea of DOMTM by $\mathrm{O}_{2}$ is much higher than for DOMTM using $\mathrm{N}_{2} \mathrm{O}$ or $\mathrm{H}_{2} \mathrm{O}_{2}$ as oxidants, because both $\mathrm{N}_{2} \mathrm{O}$ and $\mathrm{H}_{2} \mathrm{O}_{2}$ can more easily release an oxygen atom, as the main species to trigger the oxidation of $\mathrm{CH}_{4}$ to $\mathrm{CH}_{3} \mathrm{OH}$. Therefore, when using $\mathrm{O}_{2}$ as oxidant, high temperature and high activity catalysts are needed to overcome the Ea of DOMTM, which unfortunately leads to deep oxidation. However, for reaction (1) the entropy is reduced $(\Delta \mathrm{S}<0)$ while it is exothermic $(\Delta \mathrm{H}<0)$. Therefore, $\mathrm{CH}_{3} \mathrm{OH}$ production is favorable at low temperature, because a low temperature can result in a negative $\Delta G$ value (i.e., a spontaneous process), leading to a contradiction between the dynamics and thermodynamics of the DOMTM process.

Recently, several innovative studies by heterogeneous catalysis and plasma catalysis have been performed to overcome the above-mentioned challenges, which we will discuss in this review.

\section{Heterogeneous Catalysis}

Heterogeneous catalysis is more suitable for industrial application than homogeneous catalysis, being more convenient for product and catalyst recovery. A number of excellent reviews have been recently published on DOMTM, adding to the classic reviews in the field [3-5,7-9]. The collective desire on these articles was emphasized to find a breakthrough, pushing DOMTM technology closer to commercialization. Generally, seeking for efficient catalytic systems with a controllable reaction kinetics process is the key of $\mathrm{CH}_{4}$ conversion, and the dissociation of the first $\mathrm{C}-\mathrm{H}$ bond was regarded as the ratedetermining step on various $\mathrm{CH}_{4}$ conversion reactions. Basically, as shown in Figure 3, the mechanism of $\mathrm{C}-\mathrm{H}$ bond cleavage of $\mathrm{CH}_{4}$ at low temperature can be mainly classified into two categories [9]. The first mechanism involves $\mathrm{H}$ abstraction from $\mathrm{CH}_{4}$ to form $\bullet \mathrm{CH}_{3}$ 
radicals by electrophilic oxygen atoms, while the other mechanism includes the formation of metal- $\mathrm{CH}_{3}(\mathrm{M}-\mathrm{C}) \sigma$-bond as a reaction intermediate which can directly cleave the $\mathrm{C}-\mathrm{H}$ bond with concomitant coordination of the $\mathrm{CH}_{3}$ group [9].

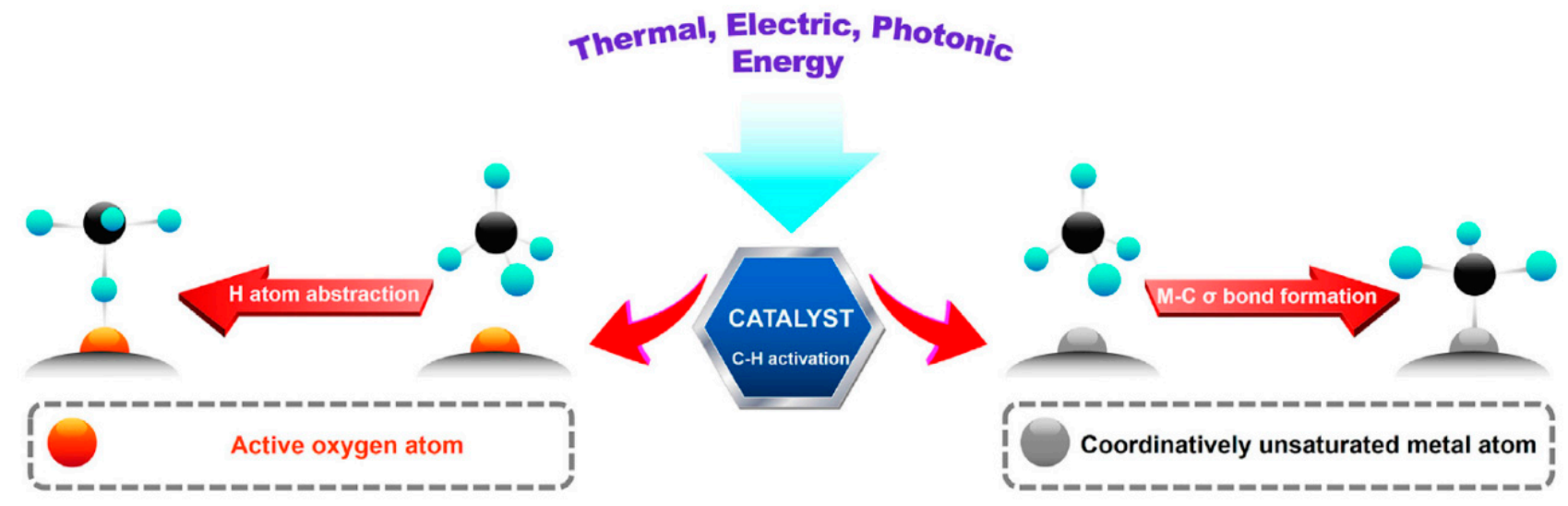

Figure 3. The mechanism of the $\mathrm{C}-\mathrm{H}$ bond cleavage of $\mathrm{CH}_{4}$ at low temperature can be classified into two categories. Reproduced from [9] with permission. Copyright 2019 Elsevier.

Except seeking advanced catalytic systems that enable efficient $\mathrm{C}-\mathrm{H}$ activation, the insight obtained in the different roles of oxidants in DOMTM will be also of benefit to the field. On the one hand, strong oxidants (e.g., $\mathrm{N}_{2} \mathrm{O}$ and $\mathrm{H}_{2} \mathrm{O}_{2}$ ) can easily break the $\mathrm{C}-\mathrm{H}$ bond, but they will also enhance the over-oxidation of intermediate products adsorbed on the catalyst surface to thermodynamically more stable $\mathrm{CO}$ or $\mathrm{CO}_{2}$, which is not conducive to the generation of $\mathrm{CH}_{3} \mathrm{OH}$ or its derivatives. On the other hand, these strong oxidants with better oxidation properties have higher raw material prices, leading to higher economic costs. In this section, we summarize the research progress of DOMTM by different oxidants (Table 1) in heterogeneous catalysis, with emphasis on the introduction of the catalytic systems with $\mathrm{O}_{2}$ as oxidant.

Table 1. Selected experimental results of direct oxidation of methane to methanol (DOMTM) based on different oxidants.

\begin{tabular}{|c|c|c|c|c|c|c|c|}
\hline Oxidant & Catalysts & $\begin{array}{l}P_{\mathrm{CH} 4} \\
\text { (bar) }\end{array}$ & $\begin{array}{l}\text { Temp } \\
\left({ }^{\circ} \mathrm{C}\right)^{\mathrm{a}}\end{array}$ & $\begin{array}{l}\mathrm{CH}_{3} \mathrm{OH} \text { Yield } \\
\left(\mu \mathrm{mol} \cdot \mathrm{g}_{\text {cat }}-1\right)\end{array}$ & $\begin{array}{c}\text { Productivity } \\
\left(\mathrm{mmol} / \mathrm{mol}_{\text {metal }}\right)\end{array}$ & $\begin{array}{l}\mathrm{CH}_{3} \mathrm{OH} \\
\text { Sel. (\%) }\end{array}$ & Ref. \\
\hline \multirow{4}{*}{$\mathrm{N}_{2} \mathrm{O}$} & $\mathrm{Fe} / \mathrm{ZSM}-5$ & $6.6 \times 10^{-4}$ & 160 & 160 & / & 76 & [25] \\
\hline & $\mathrm{Fe} / \mathrm{CHA}$ & / & RT & 26.8 & 681 & / & [26] \\
\hline & $\mathrm{Cu} / \mathrm{MOR}$ & / & 150 & 97 & $>300$ & / & [27] \\
\hline & $\mathrm{Cu} / \mathrm{SSZ}-13$ & 0.3 & 260 & 19 & / & 27 & [27] \\
\hline \multirow{6}{*}{$\mathrm{H}_{2} \mathrm{O}_{2}$} & $\mathrm{Au}-\mathrm{Pd} / \mathrm{TiO}_{2}$ & 30.5 & 2 & 54.6 & 13.1 & 45.2 & [28] \\
\hline & Au-Pd colloids & 30 & $\leq 50$ & $2.8-7.6$ & / & $14-28.3$ & [23] \\
\hline & AuPd@ZSM-5 & 0.48 & 70 & / & 91.6 & 92 & [29] \\
\hline & $\mathrm{FeN}_{4} /$ Graphene & 18 & 25 & / & / & / & [10] \\
\hline & $\mathrm{Rh} / \mathrm{ZrO}_{2}$ & 28.5 & 70 & / & 1.25 & / & [30] \\
\hline & $\mathrm{Cu}-\mathrm{Fe} / \mathrm{ZSM}-5$ & 30.8 & 50 & $5.2 \times 10^{3}$ & / & 88 & [31] \\
\hline \multirow[t]{6}{*}{$\mathrm{O}_{2}$} & $\mathrm{Cu} / \mathrm{ZSM}-5$ & / & 175 & 8.2 & / & 98 & [32] \\
\hline & $\mathrm{Cu} / \mathrm{MOR}$ & / & 200 & 170 & 0.47 & / & [33] \\
\hline & $\mathrm{Cu} / \mathrm{SSZ}-13$ & 0.1 & 200 & 125 & 0.2 & $>90$ & [34] \\
\hline & $\mathrm{Cu} /$ Omega & 30 & 200 & 200 & 265 & / & [35] \\
\hline & Co/ZSM-5 & 1 & 150 & $0.3-0.4$ & / & $40-100$ & [36] \\
\hline & $\mathrm{Ni} / \mathrm{ZSM}-5$ & 1 & 175 & 14.9 & / & / & [37] \\
\hline \multirow[t]{2}{*}{$\mathrm{O}_{2}+\mathrm{H}_{2} \mathrm{O}$} & $\mathrm{CeO}_{\mathrm{x}} / \mathrm{Cu}_{2} \mathrm{O} / \mathrm{Cu}(111)$ & $2.7 \times 10^{-5}$ & 25 & / & / & 70 & [38] \\
\hline & $\mathrm{Ni} / \mathrm{CeO}_{2}$ & $1.3 \times 10^{-3}$ & 177 & / & / & $<40$ & [39] \\
\hline $\mathrm{O}_{2}+\mathrm{CO}$ & $\mathrm{Rh} / \mathrm{ZSM}-5$ & 20 & 150 & 1224 & / & 6.2 & [24] \\
\hline $\mathrm{O}_{2}+\mathrm{H}_{2} \mathrm{O}_{2}$ & $\mathrm{RuCu} / \mathrm{NL}^{\mathrm{b}}$ & 25 & 50 & $\sim 1.5 \times 10^{3}$ & / & / & [40] \\
\hline $\mathrm{N}_{2} \mathrm{O}+\mathrm{H}_{2} \mathrm{O}$ & $\mathrm{Mo} / \mathrm{SiO}_{2}$ & / & 300 & / & 16 & 60 & [41] \\
\hline
\end{tabular}

a The temperature of the DOMTM process by chemical looping (more information on Section 2.3) is based on the step of the $\mathrm{CH}_{4}$ reaction for better comparison under the same criteria; ${ }^{\mathrm{b}}$ NL: Nanolichens. 


\subsection{Nitrous Oxide as Oxidant}

Nitrous oxide $\left(\mathrm{N}_{2} \mathrm{O}\right)$ is widely used as oxidant in DOMTM (2), mainly based on Femodified zeolites, which is particularly attractive from the perspective of natural catalysts (i.e., methane monooxygenase (MMO) enzymes), activating $\mathrm{CH}_{4}$ to produce $\mathrm{CH}_{3} \mathrm{OH}$ under mild conditions. The unique properties of $\mathrm{MMO}$ are related to the Fe-containing sites capable of generating extremely active oxygen species that can insert into non-activated $\mathrm{C}-\mathrm{H}$ bonds of $\mathrm{CH}_{4}$ under ambient conditions [42]. Great interest has been paid to Fe-based zeolites, which may contain various iron species, especially activated by $\mathrm{N}_{2} \mathrm{O}$. Early results showed that $\mathrm{Fe} / \mathrm{ZSM}-5$ catalyst can decompose $\mathrm{N}_{2} \mathrm{O}$ effectively through a $\mathrm{Fe} / \mathrm{O}$ highly active site on its surface at low temperature $\left(<300{ }^{\circ} \mathrm{C}\right)$ and realize partial oxidation of benzene to phenol $[43,44]$. This active site on the Fe/ZSM- 5 catalyst is called the $\alpha$-Fe or $\alpha-\mathrm{O}$ site, and it was found that DOMTM can be achieved at low temperature [45]. The nature of the active site with exceptional reactivity is difficult to prove spectroscopically mainly due to the presence of inactive spectator iron species.

$$
\mathrm{CH}_{4}+\mathrm{N}_{2} \mathrm{O} \rightarrow \mathrm{CH}_{3} \mathrm{OH}+\mathrm{N}_{2} \quad \Delta \mathrm{H}(298 \mathrm{~K})=-159.0 \mathrm{~kJ} \cdot \mathrm{mol}^{-1}
$$

The properties of $\alpha$-oxygen and the state of iron constituting $\alpha$-sites were studied in many experimental $[46,47]$ and theoretical works $[48,49]$ and discussed in review papers $[3,50]$. Despite great research efforts have been made, the spectroscopic insight into the structure of actual active site was illustrated only recently on Fe-BEA zeolite [46]. By magnetic circular dichroism (MCD), a mononuclear, high-spin, square planar Fe(ii) site was identified and this high-reactive site was previously regarded as an $\alpha$-Fe(II) site by Panov and co-workers. Furthermore, the $\alpha-\mathrm{O}$ site constrained by the zeolite lattice, considered as the reactive intermediate, is, actually, a mononuclear, high-spin Fe(iv) $=\mathrm{O}$ species [46]. From the DRUV-Vis spectra, an intense band at $40,000 \mathrm{~cm}^{-1}$ and three weak bands at 15,900,9000, and $5000 \mathrm{~cm}^{-1}$ were observed for the inactivated Fe-BEA (Figure 4a). After $\mathrm{N}_{2} \mathrm{O}$ activation and $\mathrm{CH}_{4}$ reaction, the peak at $16,900 \mathrm{~cm}^{-1}$, along with a weak feature at around $5000 \mathrm{~cm}^{-1}$ present after $\mathrm{N}_{2} \mathrm{O}$ activation, disappear upon reaction with $\mathrm{CH}_{4}$, which corresponds to the process of the $\alpha$-O site which forms on $\alpha$-Fe (II) active site. The $5000-13,000 \mathrm{~cm}^{-1}$ region of the $\mathrm{CH}_{4}$-reacted spectrum overlaps with that of $\mathrm{Fe}(\mathrm{II})$-BEA, indicating that features in this region originate from inactive iron species. Furthermore, the MCD spectra show a band at $15,100 \mathrm{~cm}^{-1}$ that is corresponding to the $15,900 \mathrm{~cm}^{-1}$ absorption band of the $\alpha-\mathrm{Fe}$ (II) site from DR-UV-Vis, which is sensitive to a magnetic field and temperature. Additionally, DFT-optimized cluster models with high-energy ligand-field band were predicted by CASPT2, and $\alpha$-Fe(II) site can be assigned to a high-spin, square planar Fe(II) site with four anionic $\mathrm{Si}-\mathrm{O}-\mathrm{Al}$ ligands (Figure 5), which can be further verified by DFT-calculated Mössbauer parameters.

(a) $\mathrm{Fe}(\mathrm{II})$ - BEA

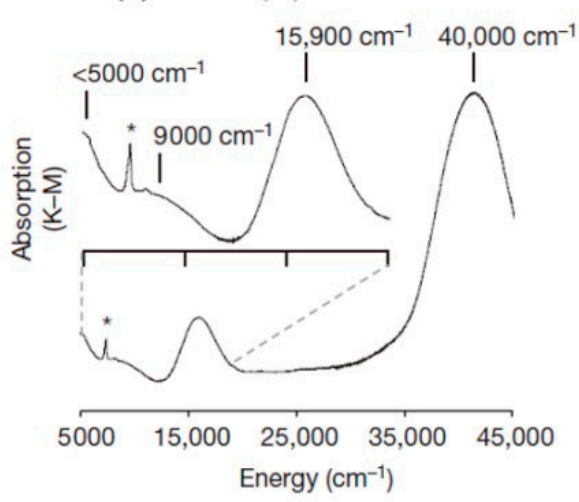

(b) $\mathrm{N}_{2} \mathrm{O}$ activation

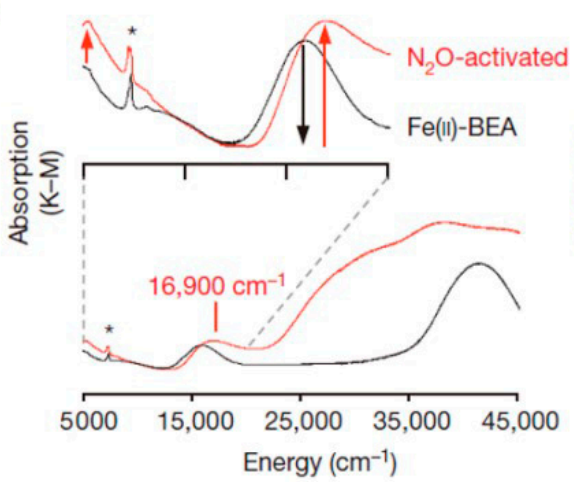

(c) $\mathrm{CH}_{4}$ reaction

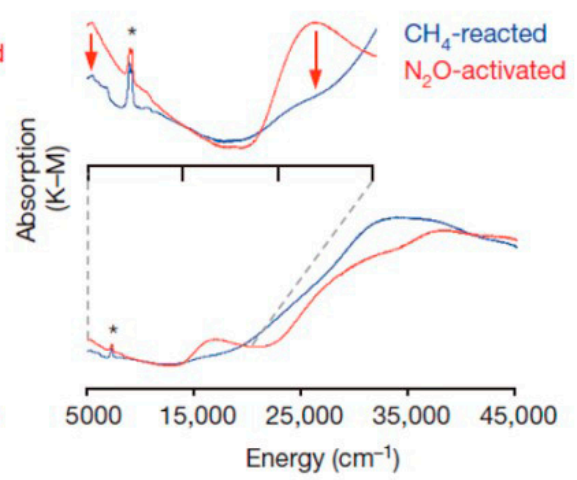

Figure 4. DR-UV-Vis spectra of Fe/BEA: (a) Before activation, (b) after $\mathrm{N}_{2} \mathrm{O}$ activation at $250{ }^{\circ} \mathrm{C}$, and (c) after reaction with $\mathrm{CH}_{4}$ at room temperature. Adapted with permission from ref [46]. Copyright 2016 Nature. 




Figure 5. DFT-optimized structure of $\alpha$-Fe (iv) $=\mathrm{O}$ sites in the $\mathrm{S}=2$ ground state. Adapted with permission from [46]. Copyright 2016 Nature.

An Fe-FER (Ferrierite) catalyst was also studied, in which the formation of active oxygen species from $\mathrm{N}_{2} \mathrm{O}$ decomposition can react with $\mathrm{CH}_{4}$ to form $\mathrm{CH}_{3} \mathrm{O}$ groups and valuable products at moderate temperatures. The emergence of methoxy group bands in the FTIR spectrum with introduction of $\mathrm{CH}_{4}$ on Fe-FER catalysts indicates the active surface species leading to the formation of selective products [51]. As shown in Figure 6, the amount of active $\alpha$-oxygen sites and number of Bronsted acid sites on the Fe-modified zeolites, e.g., Fe/ZSM-5 and Fe/FER, are crucial factors to alter $\mathrm{CH}_{4}$ conversion and product distribution as well [52]. The Fe/ZSM-5 zeolite, with a large number of strong acid sites, could produce a higher selectivity to unsaturated $C_{2}-C_{3}$ hydrocarbons and dimethyl ether (DME), while the Fe/FER zeolite, with a large number of weak Bronsted acid sites, gave rise to oxygenates such as $\mathrm{CH}_{3} \mathrm{OH}$ and DME [52]. The formed coke precursors seem to be more dominant on the Fe/ZSM-5 zeolite with stronger acid sites due to a facile reaction pathway through the MTO reaction. The amount of coke deposition on acid sites and $\alpha$-oxygen sites was well correlated with the catalytic performance, and thus a possible reaction pathway (Figure 6) was proposed by the authors, based on the product distribution with respect to acid sites and $\alpha$-oxygen sites [52]. The general consensus of DOMTM reaction pathway over $\alpha$-O sites follows a radical-based $\mathrm{H}$ atom abstraction mechanism (cf. Figure 3), although some steps based on this mechanism are still debated. Briefly, oxygen atoms are introduced by $\mathrm{N}_{2} \mathrm{O}$ decomposition before subsequent $\mathrm{CH}_{4}$ addition. The abstracted hydrogen atom from $\mathrm{CH}_{4}$ by the $\alpha-\mathrm{O}$ results in an $\mathrm{Fe}^{\mathrm{III}}-\mathrm{O}-\mathrm{H}$ fragment and a $\mathrm{CH}_{3}$ radical, and produced $\mathrm{CH}_{3}$ radical may then either react with a further $\alpha-\mathrm{O}$ to form $\mathrm{Fe}^{\mathrm{III}}-\mathrm{O}-\mathrm{CH}_{3}$ or form $\mathrm{Fe}^{\mathrm{II}}-\mathrm{O}(\mathrm{H})-\mathrm{CH}_{3}$ with near fragment, which may then desorb and eventually form $\mathrm{CH}_{3} \mathrm{OH}[48,53]$.

The remarkable activity of the $\alpha$-O site can be partially attributed to confinement effects with the zeolite channels $[48,54]$, which are thought to increase the local concentration of the molecular orbitals within the micropores, resulting in increased interactions between confined reactants and enabling unusual transition states to be accessed. Furthermore, the confined molecules within zeolites have also been shown to induce dipoles and multi-poles, potentially strengthen or weaken some $\mathrm{C}-\mathrm{C}$ bonds, which may lead to modifications of the HOMO/LUMO energy levels.

Periodic structure and cluster modeling of $\alpha$-O sites in the SSZ-13 zeolite at different levels of theory has been performed and the results showed that the confinement effect of zeolite channels may reduce the energy barrier of DOMTM by over 50\% [48]. This confinement effect is mainly electrostatic in nature, which could stabilize all transition states, the reaction intermediate and products. DFT calculations on a periodic system of $\mathrm{MO}^{+} / \mathrm{ZSM}-5$ zeolite $(\mathrm{M}=\mathrm{Fe}, \mathrm{Co}, \mathrm{Ni}$ and $\mathrm{Cu})$ indicate that the confinement effect is attributed to the nanopores of ZSM-5 zeolites, in which interaction between $\mathrm{CH}_{4}$ and $\mathrm{MO}^{+}$species was confined [55], resulting in a significant destabilization of $\mathrm{CH}_{4}$ adsorption and further lowering of the activation energy for the $\mathrm{C}-\mathrm{H}$ bond dissociation. In addition, mono-nuclear $\alpha-\mathrm{Fe}^{2+}$ in an extra-lattice site within Fe-beta zeolite (BEA) also showed that 
the reactive intermediate was a high spin $\mathrm{Fe}^{4+}=\mathrm{O}$ species and the confinement of the zeolite lattice promotes the reactivity [46]. Therefore, by preventing geometric distortion, the confined $\alpha$-O sites can activate $\mathrm{CH}_{4}$ and cleave the strongest aliphatic $\mathrm{C}-\mathrm{H}$ bond at room temperature to form $\mathrm{CH}_{3} \mathrm{OH}$.

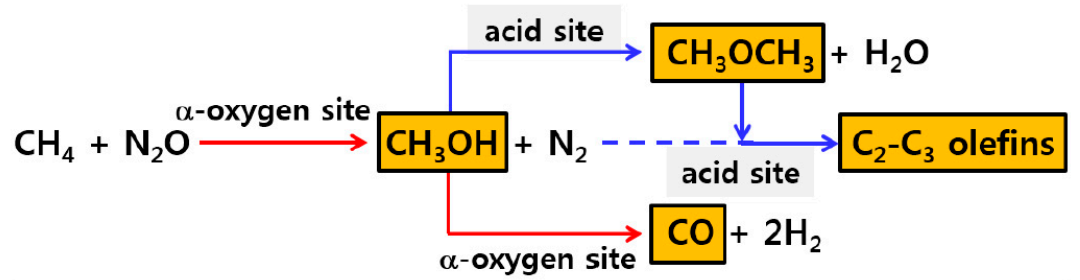

Direct activation of $\mathrm{CH}_{4}$ to oxygenates using $\mathrm{N}_{2} \mathrm{O}$ on Fe-modified zeolites

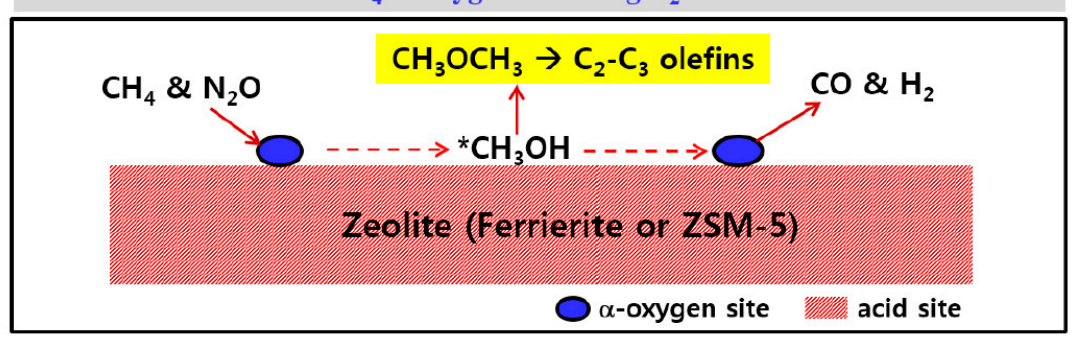

Figure 6. Scheme of direct activation of $\mathrm{CH}_{4}$ to oxygenates using $\mathrm{N}_{2} \mathrm{O}$ on Fe-modified zeolites. Adapted with permission from [52]. Copyright 2017 Elsevier.

Variant zeolite topology has thus been considered an important factor in rationally tuning of the active site properties for DOMTM. The single-site $\alpha$-Fe in the CHA topology zeolite was demonstrated to be active to form a highly reactive $\alpha-\mathrm{O}$, capable of activating $\mathrm{CH}_{4}$ at room temperature to form $\mathrm{CH}_{3} \mathrm{OH}$, which subsequently desorb from catalyst surface by on-line steaming at $200{ }^{\circ} \mathrm{C}$ [26]. It has been found that the topology's 6MR geometry of $\mathrm{CHA}$ zeolite has great effect on the structure, the ligand field, and consequently the spectroscopy of the $\alpha$-Fe site, by comparing $\alpha$-Fe in Fe/BEA and Fe/CHA. At higher Fe loading $(>0.26 \mathrm{wt} \%$; $\mathrm{Si}: \mathrm{Al}=12.5), \mathrm{Fe}_{2} \mathrm{O}_{3}$ was identified other than $\alpha$-Fe sites in Fe/CHA zeolite. Therefore, the level of introducing Fe into CHA zeolite is a crucial criterion to improve reaction reactivity with increased active site density [26]. Additionally, indicated by nitrous oxide titration, the method of introducing appropriate extra-framework $\mathrm{Al}$ in $\mathrm{Fe} / \mathrm{MOR}$ catalysts is in favor of increasing iron ions in tetrahedral or octahedral coordination, which can promote the formation of more $\alpha$-sites in Fe-containing zeolites [56].

The DMTOM process was studied in a so-called quasi-catalytic mode over Fe/ZSM-5 zeolite with $\mathrm{N}_{2} \mathrm{O}$ as an oxidant, in which the reaction intermediates or products just migrate from catalytically active centers to other sites of the surface, rather than desorption into the gas phase, mainly due to the activation energy of surface diffusion of adsorbed species is much smaller than desorption energy of the species into the gas phase [25,57]. As shown in Figure 7, the produced $\mathrm{CH}_{3} \mathrm{OH}$ over $\alpha$-O sites moved to neighboring sites without desorption into the gas phase in the quasi-catalytic mode, and the adsorbed species could further be converted to coke or extracted from surface to get methanol and dimethyl ether (DME). The reaction could switch to conventional catalytic process at above $200{ }^{\circ} \mathrm{C}$, with products direct desorption into gas phase. Low $\mathrm{CH}_{4}$ conversion $(0.19 \%)$ is indeed a huge limitation for DOMTM reaction, but this approach provides new insight and a possibility to identify the potential intermediates [57].

In addition to Fe-modified zeolites, some other catalysts have been also studied for DOMTM by using $\mathrm{N}_{2} \mathrm{O}$ as an oxidant. Liu et al. investigated the catalytic performance of a Mo-based catalyst in partial oxidation of $\mathrm{CH}_{4}$ to $\mathrm{CH}_{3} \mathrm{OH}$ using $\mathrm{N}_{2} \mathrm{O}$ as oxidant. However, only $3 \% \mathrm{CH}_{4}$ conversion was achieved with $78 \%$ oxygenates selectivity $\left(\mathrm{CH}_{3} \mathrm{OH}\right.$ and $\mathrm{HCHO}$ ) [58]. Cu/SSZ-13 catalyst activated by $\mathrm{N}_{2} \mathrm{O}$ was also reported for DOMTM at low temperatures and ambient pressure, with highest $\mathrm{CH}_{3} \mathrm{OH}$ productivity 
of $55 \mu \mathrm{mol} \mathrm{CH}_{3} \mathrm{OH} \mathrm{g}^{-1} \mathrm{~h}^{-1}$, which was more than twice the rate of $\mathrm{Cu}$-mordenite and more than four times the rate of Cu-ZSM-5 [59]. Higher partial pressures of $\mathrm{CH}_{4}$ and $\mathrm{H}_{2} \mathrm{O}$ with lower $\mathrm{N}_{2} \mathrm{O}$ partial pressure was thought to further improve $\mathrm{CH}_{3} \mathrm{OH}$ selectivity [59]. Recently, the performance of $\mathrm{N}_{2} \mathrm{O}$ and $\mathrm{O}_{2}$ oxidants were compared by DFT calculation on the $\mathrm{CoN}_{3}-\mathrm{Graphene}$ catalyst, and the results shows that DOMTM reaction can proceed via a two-step pathway, with $\mathrm{N}_{2} \mathrm{O}$ as an oxygen donor [60]. $\mathrm{CoN}_{3}-$ Graphene catalyst exhibited higher catalytic activity for the adsorption of gas reactants, which can be used as an efficient catalyst to fabricate effective $\mathrm{C} / \mathrm{N}$ catalysts on methane oxidation by $\mathrm{N}_{2} \mathrm{O}$.

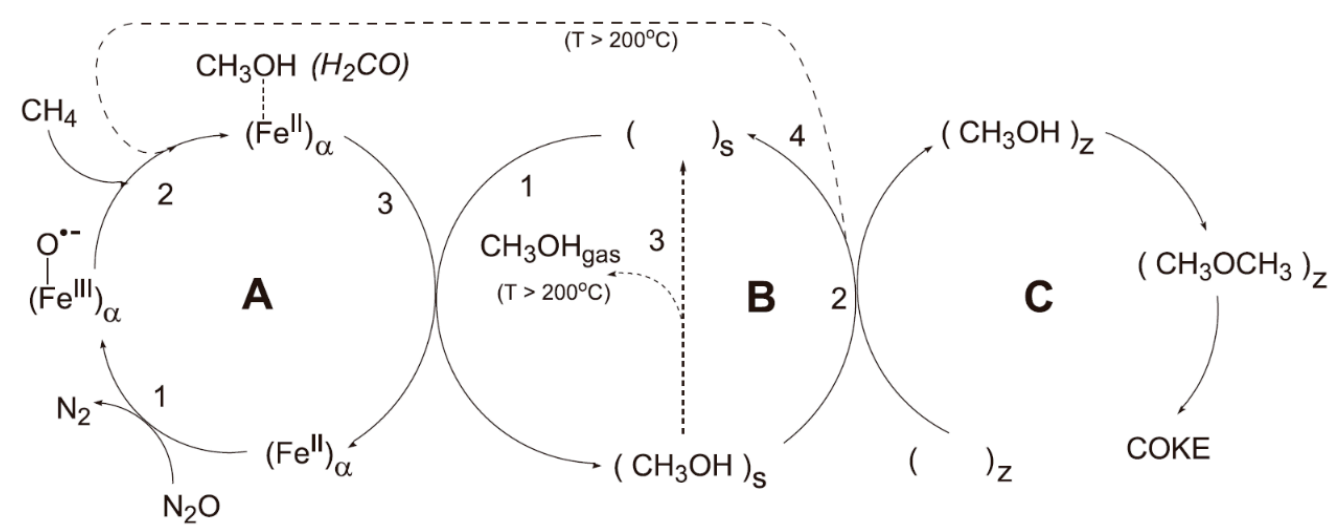

Figure 7. Mechanistic scheme of quasi-catalytic and catalytic oxidation of $\mathrm{CH}_{4}$ by $\mathrm{N}_{2} \mathrm{O}$. Reprinted with permission from [57]. Copyright 2014 Elsevier.

$\mathrm{N}_{2} \mathrm{O}$, a relatively stable greenhouse gas (GHGs), mainly from agricultural production and other anthropogenic activities, like waste management, or the combustion of fossil fuels and biomass, which could be correlated to stratospheric ozone destruction by atmospheric photochemical reactions [61]. Indeed, the co-conversion of $\mathrm{CH}_{4}$ and $\mathrm{N}_{2} \mathrm{O}$ is of great interest in reducing the anthropogenic forcing of the climate system, as a win-win strategy for both ozone and climate. However, the utilization of $\mathrm{N}_{2} \mathrm{O}$ as an oxidant confronts an insurmountable hurdle associated with its low availability which cannot satisfy the large demand for industrial scale $\mathrm{CH}_{4}$ valorization.

\subsection{Hydrogen Peroxide as an Oxidant}

As an important industrial oxidant, hydrogen peroxide $\left(\mathrm{H}_{2} \mathrm{O}_{2}\right)$ is widely used in papermaking, sewage treatment, metallurgy, medical and health care, and other fields [62]. The benefit of $\mathrm{H}_{2} \mathrm{O}_{2}$ oxidant is the clean decomposition to water as an environmentally benign byproduct. Noticeably, $\mathrm{H}_{2} \mathrm{O}_{2}$ has been considered as a highly efficient oxidant in DOMTM (3). Many studies realized the DOMTM process under milder conditions compared to $\mathrm{N}_{2} \mathrm{O}$ oxidant, mainly employing noble metal catalysts.

$$
\mathrm{CH}_{4}+\mathrm{H}_{2} \mathrm{O}_{2} \rightarrow \mathrm{CH}_{3} \mathrm{OH}+\mathrm{H}_{2} \mathrm{O} \quad \Delta \mathrm{H}(298 \mathrm{~K})=-223.9 \mathrm{~kJ} \cdot \mathrm{mol}^{-1}
$$

Singly dispersed noble metal atoms anchored on oxides could offer a distinctly different electronic state in contrast to continuously packed metal atoms on the surface of a metal nanoparticle, and thus could exhibit a distinct catalytic activity or /and selectivity [63,64]. $\mathrm{Pd}_{1} \mathrm{O}_{4}$ single-sites anchored on the internal surface of micropores of ZSM-5 exhibited excellent performance for $\mathrm{CH}_{4}$ activation [65]. Under the assistance of $\mathrm{H}_{2} \mathrm{O}_{2}, \mathrm{CH}_{4}$ was partially oxidized into $\mathrm{CH}_{3} \mathrm{OH}$ over $\mathrm{Pd}_{1} \mathrm{O}_{4}$ site at low temperature $\left(50-95{ }^{\circ} \mathrm{C}\right)$, but extra $\mathrm{H}_{2} \mathrm{O}_{2}$ resulted in further oxidation of $\mathrm{CH}_{3} \mathrm{OH}$ to $\mathrm{CHOOH}$. The $\mathrm{CH}_{3} \mathrm{OH}$ selectivity remained at $86.4 \%$, while the $\mathrm{CH}_{3} \mathrm{OH}$ productivity at $95^{\circ} \mathrm{C}$ was about 2.78 molecules per $\mathrm{Pd}_{1} \mathrm{O}_{4}$ site per second when $\mathrm{CuO}$ was used as a co-catalyst. The experiment of varied amounts of Pd on Pd/ZSM-5 catalysts exhibited quite similar yields of the products, although their loadings of $\mathrm{Pd}$ were quite different (from 0.01 to $2.0 \mathrm{wt} . \%$ ), suggesting that the excess $\mathrm{Pd}$, present in the external surface of the zeolite, did not alter the activity, as well as the 
selectivity of $\mathrm{CH}_{3} \mathrm{OH}$. Furthermore, DFT calculations showed that $\mathrm{CH}_{3} \mathrm{OH}$ is the thermodynamically stable product over $\mathrm{Pd}_{1} \mathrm{O}_{4}$, which was consistent with the experimental result that $\mathrm{CH}_{3} \mathrm{OH}$ production was highly favorable compared to the formation of a byproduct, methylperoxide [65]. Kwon and co-workers reported an atomically dispersed $\mathrm{Rh} / \mathrm{ZrO}_{2}$ catalyst using aqueous $\mathrm{H}_{2} \mathrm{O}_{2}$ as an oxidant for the selective oxidation of $\mathrm{CH}_{4}$, where the property of $\mathrm{Rh}$ active sites significantly affected the $\mathrm{CH}_{4}$ oxidation [30]. Single atomic Rh could make $\mathrm{CH}_{3} \mathrm{OH}$ with the highest productivity, whereas $\mathrm{Rh}$ nanoparticles on $\mathrm{SiO}_{2}$ produced only $\mathrm{CO}_{2}$ without the formation of $\mathrm{C} 1$ oxygenates (Figure 11A). The amount of oxygenated products showed only a little difference up to the fifth cycle (Figure 11B). When replacing the oxidant with $\mathrm{O}_{2}, \mathrm{C}_{2} \mathrm{H}_{6}$ was observed as main product in gas-phase for direct $\mathrm{CH}_{4}$ oxidation, as shown in Figure 11C [30]. Additionally, combing EXAFS, XANES, HAADF-STEM/EDS images and CO-adsorption using DRIFTS measurements, the model of single-atom $\mathrm{Rh} / \mathrm{ZrO}_{2}$ catalyst was proposed, based on which DFT calculations were carried out. The results showed that $\mathrm{CH}_{3}$ intermediates can be energetically stabilized on the catalyst, which was further verified by DRIFTS measurements. The active single-site $\mathrm{Rh}_{1} \mathrm{O}_{5}$ anchored in microporous aluminosilicates (Rh/ZSM-5) in solution can realize the oxidation of $\mathrm{CH}_{4}$ to $\mathrm{CH}_{3} \mathrm{COOH}$ (acetic acid) and $\mathrm{CH}_{3} \mathrm{OH}$ below $150{ }^{\circ} \mathrm{C}$ [66]. An isotope experiment confirmed that the $\mathrm{C}$ atoms of the methyl and carboxyl groups in $\mathrm{CH}_{3} \mathrm{COOH}$ were derived from $\mathrm{CH}_{4}$ and $\mathrm{CO}$, respectively. Noticeably, high pressure of $\mathrm{CO}$ is detrimental to the production of $\mathrm{CH}_{3} \mathrm{COOH}$ and finally poisoned the active sites [66]. The conversion of $\mathrm{CH}_{4}$ to oxygenates on $\mathrm{Rh} / \mathrm{ZSM}-5$ may occur via $\mathrm{M}-\mathrm{CH}_{3}$ functionalization. Firstly, $\mathrm{CH}_{4}$ is activated in the presence of $\mathrm{O}_{2}$ on isolated $\mathrm{Rh}^{+}$cations under mild conditions to produce $\mathrm{Rh}-\mathrm{CH}_{3}$. The formed $\mathrm{Rh}-\mathrm{CH}_{3}$ can then be functionalized via two independent reaction pathways: oxygen insertion to produce $\mathrm{CH}_{3} \mathrm{OH}$, or $\mathrm{CO}$ insertion to produce $\mathrm{CH}_{3} \mathrm{COOH}$. After a hydrolysis step, the whole catalytic cycle can be completed [24]. However, the indepth mechanism responsible for this activation is still not clear and further investigation is indispensable to guide the design of novel and more efficient $\mathrm{CH}_{4}$ oxidation catalysts.

Interestingly, Au-Pd nanoparticles (NP) are highly effective catalysts for the direct synthesis of $\mathrm{H}_{2} \mathrm{O}_{2}$, and the hydroperoxy species (HOO) is effective for the oxidation reaction [67]. Thus, $\mathrm{Au}-\mathrm{Pd}$ supported nanoparticles $\left(\mathrm{AuPd} / \mathrm{TiO}_{2}\right)$ are active for the oxidation of $\mathrm{CH}_{4}$, giving a high selectivity for $\mathrm{CH}_{3} \mathrm{OH}$ formation under mild aqueous conditions with $\mathrm{H}_{2} \mathrm{O}_{2}$ as oxidant [28]. A similar productivity, but with improved $\mathrm{CH}_{3} \mathrm{OH}$ selectivity, was observed when using the in situ generated $\mathrm{H}_{2} \mathrm{O}_{2}$ by adding $\mathrm{H}_{2} / \mathrm{O}_{2}$ gases mixture, compared to the experiments performed with pre-synthesized $\mathrm{H}_{2} \mathrm{O}_{2}$. Additionally, both methyl $\left(\bullet \mathrm{CH}_{3}\right)$ and hydroxyl $(\bullet \mathrm{OH})$ radicals were observed by electron paramagnetic resonance (EPR) spectroscopy, which suggests that the $\mathrm{CH}_{4}$ reaction proceeds through a radical mechanism, in contrast to the reaction mechanism previously proposed for $\mathrm{CH}_{4}$ oxidation using $\mathrm{CuFe} / \mathrm{ZSM}-5$, where $\bullet \mathrm{CH}_{3}$ radicals were not observed [31].

Recently, further experiments showed that colloidal Au-Pd nanoparticles can oxidize $\mathrm{CH}_{4}$ in aqueous solution at mild temperatures with $92 \% \mathrm{CH}_{3} \mathrm{OH}$ selectivity, in the presence of both $\mathrm{H}_{2} \mathrm{O}_{2}$ and $\mathrm{O}_{2}$ [23]. Different components of the catalyst were studied for the $\mathrm{H}_{2} \mathrm{O}_{2}$ degradation rates. $\mathrm{H}_{2} \mathrm{O}_{2}$ degradation rates of bare $\mathrm{TiO}_{2}$ and unsupported $\mathrm{Au}-\mathrm{Pd}$ colloidal NPs were low, while the Au-Pd/ $\mathrm{TiO}_{2}$ catalyst exhibited a high rate of $\mathrm{H}_{2} \mathrm{O}_{2}$ degradation $(73 \%)$, indicating that either the interfacial sites at the support/metal interface or a change in the morphology of the NP led to the high $\mathrm{H}_{2} \mathrm{O}_{2}$ degradation rates [67-70]. The Au-Pd colloid catalyst decomposes $\mathrm{H}_{2} \mathrm{O}_{2}$ at a much lower rate (38\%) but makes substantially more products. Moreover, the addition of 5 bar of $\mathrm{O}_{2}$ pressure to the reaction resulted in an increased yield of oxygenate products (e.g., $\mathrm{CH}_{3} \mathrm{OH}, \mathrm{CH}_{3} \mathrm{OOH}$ and $\mathrm{HCOOH}$ ) compared with the $\mathrm{H}_{2} \mathrm{O}_{2}$-only reaction. Isotopically labeled oxygen $\left(\mathrm{O}_{2}\right)$ as oxidant in the presence of $\mathrm{H}_{2} \mathrm{O}_{2}$ indicated that the produced $\mathrm{CH}_{3} \mathrm{OH}$ incorporated a substantial fraction $(70 \%)$ of gasphase $\mathrm{O}_{2}$ under optimized conditions, which can react with $\bullet \mathrm{CH}_{3}$ radicals generated via $\mathrm{H}$ abstraction by $\bullet \mathrm{OH}$ from $\mathrm{H}_{2} \mathrm{O}_{2}$ as initiation step of $\mathrm{CH}_{4}$ activation (Figure 8). Additionally, more oxygenated products were formed than the amount of $\mathrm{H}_{2} \mathrm{O}_{2}$ consumed, suggesting that the controlled breakdown of $\mathrm{H}_{2} \mathrm{O}_{2}$ activates $\mathrm{CH}_{4}$, which subsequently incorporates 
$\mathrm{O}_{2}$ through a radical process [23]. Titania-supported AuPdCu catalysts are active for the oxidation of $\mathrm{CH}_{4}$ under mild reaction conditions by using $\mathrm{H}_{2} \mathrm{O}_{2}$ as oxidant. After depositing $\mathrm{Cu}$ together with $\mathrm{Au} / \mathrm{Pd}$ on the surface of $\mathrm{TiO}_{2}$ the rate of $\mathrm{CH}_{4}$ oxidation with addition of $\mathrm{H}_{2} \mathrm{O}_{2}$ is significantly enhanced. In particular, 2.5\% $\mathrm{Au} 2.5 \% \mathrm{Pd} 1.0 \% \mathrm{Cu} / \mathrm{TiO}_{2}$ showed ca. $83 \%$ selectivity to $\mathrm{CH}_{3} \mathrm{OH}$ [71].



Figure 8. Proposed reaction scheme for $\mathrm{CH}_{4}$ oxidation in the presence of $\mathrm{H}_{2} \mathrm{O}_{2}$ and molecular $\mathrm{O}_{2}$. Reproduced with permission from [23]. Copyright 2017 American Association for the advancement of science.

To make $\mathrm{CH}_{4}$ economically competitive as a source of energy, it is crucial to increase the productivity of $\mathrm{CH}_{3} \mathrm{OH}$ and the efficiency of $\mathrm{H}_{2} \mathrm{O}_{2}$ utility [72]. DOMTM by AuPd@ZSM-5 catalyst (Figure 9) using in situ generated $\mathrm{H}_{2} \mathrm{O}_{2}$ at mild temperature $\left(70{ }^{\circ} \mathrm{C}\right)$ has been reported, which can prevent $\mathrm{H}_{2} \mathrm{O}_{2}$ dilution, and thereby keep a high local concentration of $\mathrm{H}_{2} \mathrm{O}_{2}$ around the AuPd nanoparticles [29]. This hydrophobic zeolite was synthesized by AuPd alloy nanoparticles within aluminosilicate zeolite crystals, where the external surface of the zeolite was modified by organosilanes, as depicted in Figure 9. The hydrophobic sheath appears to allow diffusion of $\mathrm{H}_{2}, \mathrm{O}_{2}$, and $\mathrm{CH}_{4}$ to the catalyst active sites, while it hinders the diffusion of generated $\mathrm{H}_{2} \mathrm{O}_{2}$ from the encapsulated AuPd nanoparticles. As shown in Figure 10A, the AuPd@ZSM-5-C3 catalyst gave a $\mathrm{CH}_{4}$ conversion of $16.4 \%$ with $\mathrm{CH}_{3} \mathrm{OH}$ selectivity of $90 \%$, and higher conversions were realized over AuPd@ZSM-5-C6 and AuPd@ZSM-5-C16 catalysts that contained longer organic chains modified on the zeolite crystals. The AuPd@ZSM-5-C16 catalysts exhibited the best performance with 17.3\% $\mathrm{CH}_{4}$ conversion and $92 \% \mathrm{CH}_{3} \mathrm{OH}$ selectivity, corresponding to $\mathrm{CH}_{3} \mathrm{OH}$ productivity up to 91.6 millimoles per gram of AuPd per hour. Additionally, the formation of $\mathrm{H}_{2} \mathrm{O}_{2}$ from $\mathrm{H}_{2}$ and $\mathrm{O}_{2}$ over AuPd@ZSM- 5 catalysts was also studied, as shown in Figure 10B. Washing the solid catalysts by cold $\mathrm{CH}_{3} \mathrm{OH}$ and tetrahydrofuran $\left(\sim 0^{\circ} \mathrm{C}\right)$, which can liberate the $\mathrm{H}_{2} \mathrm{O}_{2}$ within the zeolite crystals, 8.1, 68.4, and $78.3 \mu \mathrm{mol}$ of $\mathrm{H}_{2} \mathrm{O}_{2}$ was obtained during this process for AuPd@ZSM-5, AuPd@ZSM-5-C3, and AuPd@ZSM-5-C16, respectively. In contrast, the $\mathrm{H}_{2} \mathrm{O}_{2}$ quantity in the water solution reached $97.9 \mathrm{mmol}$ when the AuPd@ZSM5 catalyst was used, which further suggests that AuPd@ZSM-5-C16 catalyst can enrich the $\mathrm{H}_{2} \mathrm{O}_{2}$ within the zeolite crystals. This molecular-fence concept seems interesting and represents a large step toward the application of direct $\mathrm{CH}_{4}$ oxidation to valuable products. However, the $\mathrm{CH}_{3} \mathrm{OH}$ productivity still needs further improvement, and the batchwise operation restricts the commercial application [29].

In addition to the above-mentioned precious metal catalysts, some cheap metal catalysts have also been studied in DOMTM using $\mathrm{H}_{2} \mathrm{O}_{2}$ as oxidant. Xie and co-workers studied the performance of $\mathrm{TiO}_{2}$-supported iron catalysts in DOMTM at ambient conditions [73]. It was observed that the $\mathrm{H}_{2} \mathrm{O}_{2}$ amount was vital for controlling the $\mathrm{CH}_{3} \mathrm{OH}$ selectivity. When no $\mathrm{H}_{2} \mathrm{O}_{2}$ was present, no $\mathrm{CH}_{4}$ was converted. Increasing the $\mathrm{H}_{2} \mathrm{O}_{2}$ amount results in a higher $\mathrm{CH}_{4}$ conversion, but the $\mathrm{CH}_{3} \mathrm{OH}$ selectivity decreased. The optimal ratio of $\mathrm{H}_{2} \mathrm{O}_{2}$ to $\mathrm{CH}_{4}$ was 0.11 , showing a $15 \% \mathrm{CH}_{4}$ conversion and an alcohol selectivity over $97 \%\left(\mathrm{CH}_{3} \mathrm{OH}\right.$ selectivity over 90\%) [73]. Xu and coworkers studied DOMTM over $\mathrm{Cu}$ - and Fe-modified ZSM-5 catalysts in a flow reactor using $\mathrm{H}_{2} \mathrm{O}_{2}$ as the oxidant under continuous flow operation. Co-impregnation of ZSM-5 with Fe and $\mathrm{Cu}$ by chemical vapour impregnation yielded catalysts that showed high $\mathrm{CH}_{3} \mathrm{OH}$ selectivity ( $>92 \%$ selectivity, $0.5 \%$ conversion) [74]. In another study, Kim et al. reported partial oxidation of $\mathrm{CH}_{4}$ over Fe/ZSM-5 catalyst using $\mathrm{H}_{2} \mathrm{O}_{2}$ as oxidant, and found that the total product yield and the amount of $\mathrm{H}_{2} \mathrm{O}_{2}$ 
consumed increased with increasing Fe content in the Fe/ZSM-5 catalyst prepared using an ion-exchange method [75]. The effect of Si:Al molar ratio of $\mathrm{Cu}$ - and Fe-exchanged zeolites on DOMTM was also studied and the results demonstrated that high $\mathrm{CH}_{3} \mathrm{OH}$ production can be realized when catalysts with low $\mathrm{Si}$ :Al ratio were used [76]. The Fe-only ZSM-5 catalysts exhibited the highest catalytic activity (total oxygenated products) with $\mathrm{HCOOH}$ being the major product, which can be explained by the increased amount of Brønsted acid sites. The presence of $\mathrm{Cu}$ aims to maintain high $\mathrm{MeOH}$ selectivity by suppressing the production of the deeper oxidation product like $\mathrm{CH}_{3} \mathrm{COOH}$ and $\mathrm{HCOOH}$ [76].
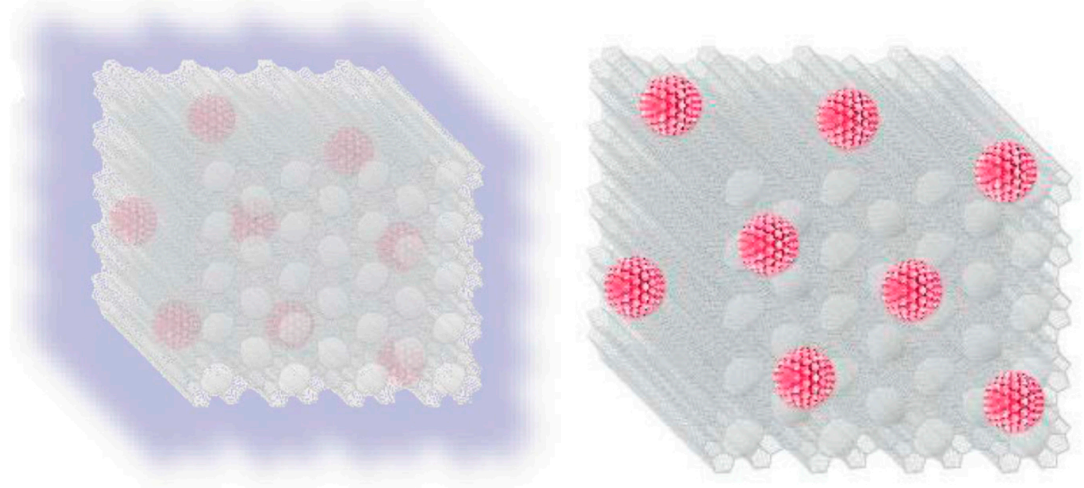

Figure 9. Models of the AuPd@ZSM-5-R (left) and AuPd/ZSM-5 (right) catalysts AuPd@Zeolite-R, where the @ symbol denotes encapsulation of the nanoparticles within the zeolite and R indicates the organic substituent of the silane sheath; A conventional ZSM-5 zeolite-supported AuPd nanoparticle catalyst was prepared by impregnating with the same loading, denoted as AuPd/ZSM-5. Reproduced with permission from [29]. Copyright 2020 American Association for the advancement of science.

A graphene-confined single Fe atom catalyst (FeN $4 / \mathrm{GN})$ was screened from a series of $3 \mathrm{~d}$ metal- $\mathrm{N}_{4}$ embedded in the lattice structure of graphene nano-sheets, as shown in Figure 12A,B. The unique $\mathrm{O}-\mathrm{FeN}_{4}-\mathrm{O}$ structure formed in graphene can directly convert $\mathrm{CH}_{4}$ to $\mathrm{C} 1$ oxygenated products (e.g., $\mathrm{CH}_{3} \mathrm{OH}, \mathrm{CH}_{3} \mathrm{OOH}, \mathrm{HCOOH}$ and $\mathrm{HOCH}_{2} \mathrm{OOH}$ ), with total selectivity around $94 \%$ [10]. The $\mathrm{CH}_{4}$ oxidation reaction was carried out in a specifically designed high-pressure reactor connected with an operando time-of-flight mass spectrometer (TOF-MS) (Figure 12C), which can successfully accomplish the qualitative and quantitative identification of products during reaction and can detect how $\mathrm{CH}_{4}$ is exactly oxidized stepwise at a more real-time analysis. The $\mathrm{CH}_{3}$ radical is first converted into $\mathrm{CH}_{3} \mathrm{OH}$ and $\mathrm{CH}_{3} \mathrm{OOH}$, and $\mathrm{CH}_{3} \mathrm{OH}$ can be further converted to $\mathrm{HOCH}_{2} \mathrm{OOH}$ and $\mathrm{HCOOH}$ on the $\mathrm{O}-\mathrm{FeN}_{4}-\mathrm{O}$ site (Figure $12 \mathrm{D}, \mathrm{E}$ ), as illustrated by TOF-MS, ${ }^{13} \mathrm{C} \mathrm{NMR}$, and DFT calculations. The intermediate $\mathrm{HOCH}_{2} \mathrm{OOH}$ was the first time to be identified as a product in $\mathrm{CH}_{4}$ oxidation. Comparison studies between the formation energies of $\mathrm{O}-\mathrm{MN}_{4}-$ $\mathrm{O}$ active sites illustrated that among all $\mathrm{O}-\mathrm{MN}_{4}-\mathrm{O}(\mathrm{M}=\mathrm{Cr}, \mathrm{Mn}, \mathrm{Fe}$, and $\mathrm{Co})$ structures, $\mathrm{O}-$ $\mathrm{FeN}_{4}-\mathrm{O}$ has a moderate formation energy and the highest $\mathrm{CH}_{4}$ activation rate (Figure $12 \mathrm{~F}$ ), corroborating well with the best activity of the $\mathrm{FeN}_{4}$ site in the experimental studies. Recently, Meysam et al. studied the influence of zeolite acidity on partial oxidation of $\mathrm{CH}_{4}$ over M-Fe-MFI (M: Ga, Al, B) zeolites [77]. The results indicated that the $\mathrm{HCOOH}$ production rate and total formation rate of oxygenated compounds correlated with total acidity. The samples with weaker acidity showed much lower oxygenate productivity and selectivity. Partial oxidation of $\mathrm{C}_{2} \mathrm{H}_{6}$ to oxygenates using Fe- and $\mathrm{Cu}$-containing ZSM-5 catalysts revealed that the Fe/ZSM- 5 catalyst is highly selective for the conversion of $\mathrm{C}_{2} \mathrm{H}_{6}$ to a range of oxygenates at appreciable levels of conversion under mild conditions [78]. The reaction pathway is more complicated than that previously proposed for the $\mathrm{CH}_{4}$ oxidation reaction using similar zeolite catalysts. 

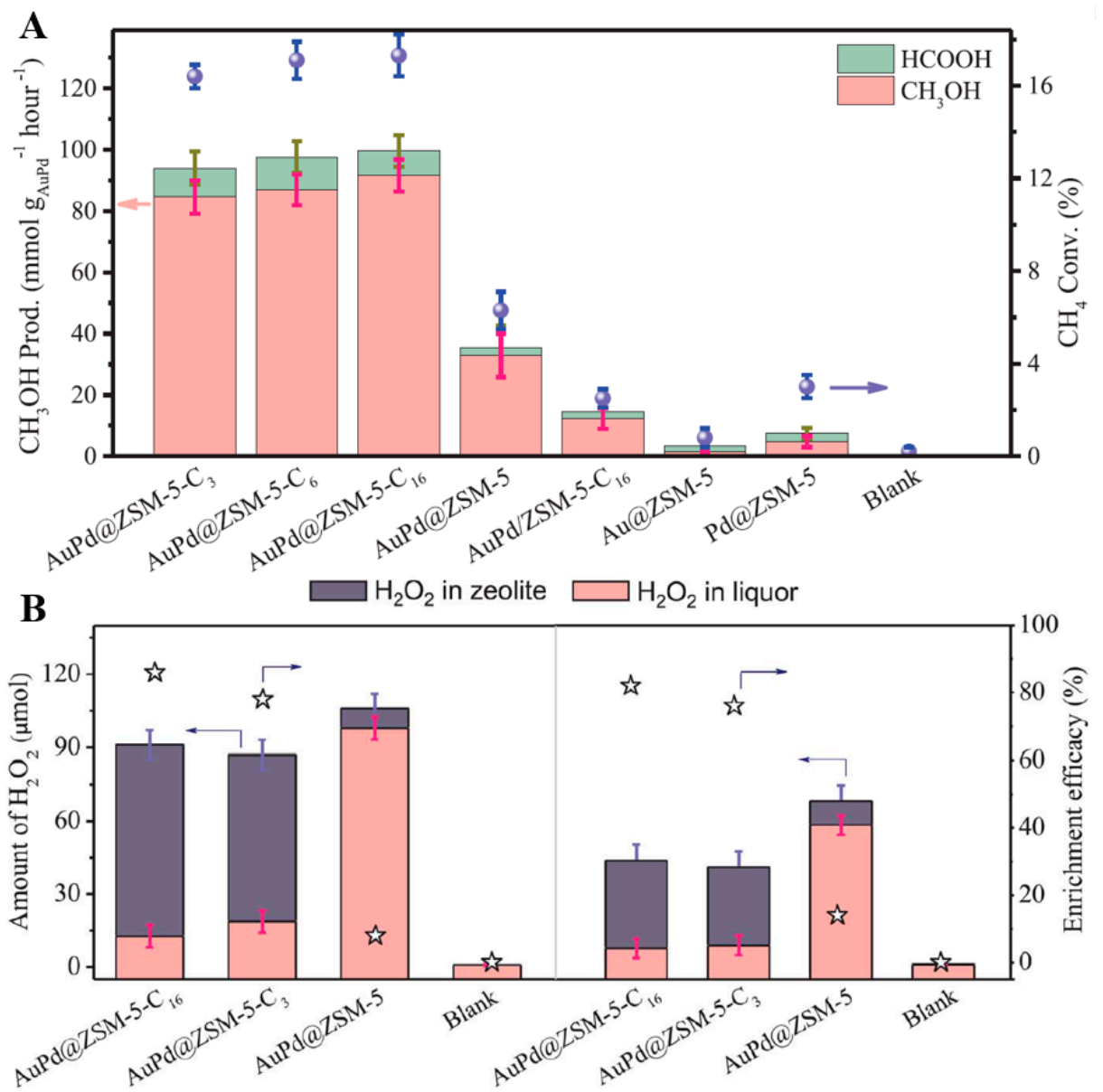

Figure 10. (A) Data characterizing the oxidation of $\mathrm{CH}_{4}$ with $\mathrm{H}_{2}$ and $\mathrm{O}_{2}$ over various catalysts. (B) Data showing the amount of $\mathrm{H}_{2} \mathrm{O}_{2}$ in the (left) $\mathrm{H}_{2} \mathrm{O}_{2}$ synthesis and (right) $\mathrm{CH}_{4}$ oxidation process. The enrichment efficacy is the percentage of $\mathrm{H}_{2} \mathrm{O}_{2}$ in zeolite crystals to the total amount of $\mathrm{H}_{2} \mathrm{O}_{2}$ in the reactor. Reaction conditions for $\mathrm{CH}_{4}$ oxidation-10 mL of water, $30 \mathrm{~min}, 70{ }^{\circ} \mathrm{C}, 27 \mathrm{mg}$ of catalyst, 3.0 $\mathrm{MPa}$ of feed gas with $3.3 \% \mathrm{H}_{2} / 6.6 \% \mathrm{O}_{2} / 1.6 \% \mathrm{CH}_{4} / 61.7 \% \mathrm{Ar} / 26.8 \% \mathrm{He}, 15 \mathrm{~min}$ and $1200 \mathrm{rpm}$. Each reaction was tested eight times to obtain the error bars. Reproduced with permission from [29]. Copyright 2020 American Association for the advancement of science.

\subsection{Oxygen as Oxidants}

As one of the main components in the air, oxygen $\left(\mathrm{O}_{2}\right)$ is an inexpensive oxidant, which is conducive to large-scale application from an economic point of view. However, as an oxidant, oxygen has a high reaction energy barrier and requires a high temperature to activate $\mathrm{CH}_{4}$ to $\mathrm{CH}_{3} \mathrm{OH}$ formation (1). In order to avoid excessive oxidation of $\mathrm{CH}_{3} \mathrm{OH}$ or its derivatives, researchers proposed a stepwise process (Figure 13) (i.e., stoichiometric chemical looping), which involves three separate steps: (1) Activation of the metal-zeolite catalyst by an oxidant at a relative high temperature $\left(250-500{ }^{\circ} \mathrm{C}\right),(2) \mathrm{CH}_{4}$ reaction at a relatively low temperature $\left(25-200{ }^{\circ} \mathrm{C}\right)$, and $(3) \mathrm{CH}_{3} \mathrm{OH}$ extraction using a solvent or steam at a relatively low temperature $\left(25-200{ }^{\circ} \mathrm{C}\right)[3,32,78]$. Both $\mathrm{O}_{2}$ and $\mathrm{N}_{2} \mathrm{O}$ can be used as oxidant for the metal-zeolite catalyst activation (Step 1), $\mathrm{N}_{2} \mathrm{O}$ could generally operate under lower temperature than $\mathrm{O}_{2}$, but in this section we mainly focus on the selected catalysts based on $\mathrm{O}_{2}$ as oxidant. Currently, $\mathrm{Cu}$ and Fe exchanged zeolites have been extensively studied, and significant attention was given to elucidating the nature of the active sites. The identity of the catalytic sites (Figure 14) in the active $\mathrm{Cu}$-zeolites was subject of many spectroscopic studies, which mainly include copper monomers, dimers in the form of mono- $\mu$-oxo and bis- $\mu$-oxo dicopper cores, trimers and larger clusters on the basis of powder XRD, EXAFS, Raman, and UV-Vis data [8,79]. 

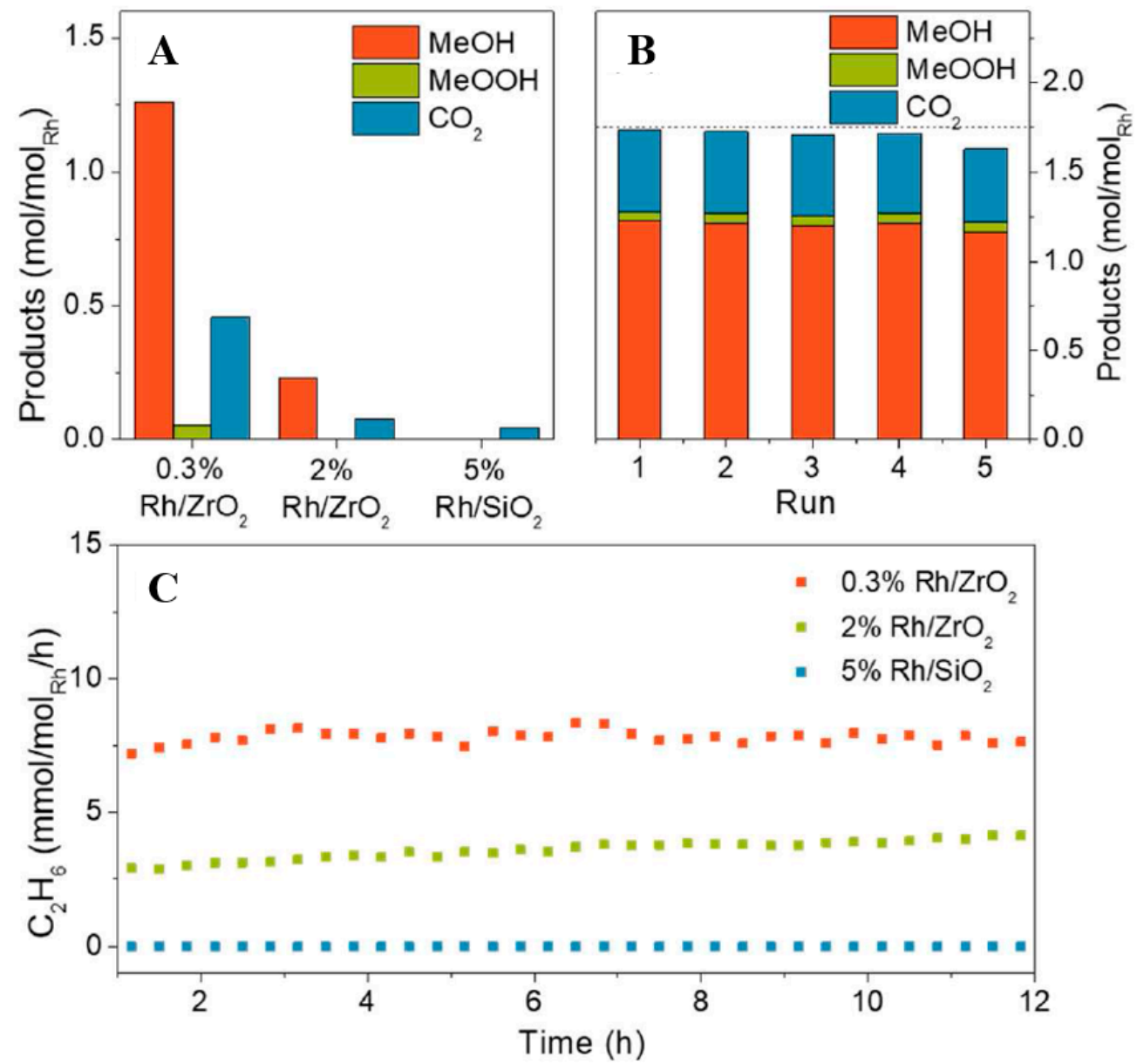

Figure 11. (A) Direct $\mathrm{CH}_{4}$ oxidation results using $\mathrm{H}_{2} \mathrm{O}_{2}$ as oxidant in aqueous solution on $0.3 \mathrm{wt} \%$ $\mathrm{Rh} / \mathrm{ZrO}_{2}, 2 \mathrm{wt} \% \mathrm{Rh} / \mathrm{ZrO}_{2}$, and $5 \mathrm{wt} \% \mathrm{Rh} / \mathrm{SiO}_{2}$ catalysts. (B) Recyclability test results performed with the $0.3 \mathrm{wt} \% \mathrm{Rh} / \mathrm{ZrO}_{2}$ catalyst. Reaction condition-30 bar of $95 \% \mathrm{CH}_{4} / \mathrm{He}, 70{ }^{\circ} \mathrm{C}, 1 \mathrm{~h}, 0.5 \mathrm{M}$ $\mathrm{H}_{2} \mathrm{O}_{2}$ and catalyst $30 \mathrm{mg}$. (C) Direct $\mathrm{CH}_{4}$ conversion to $\mathrm{C}_{2} \mathrm{H}_{6}$ using $\mathrm{O}_{2}$ as oxidant in gas-phase on $0.3 \mathrm{wt} \% \mathrm{Rh} / \mathrm{ZrO}_{2}, 2 \mathrm{wt} \% \mathrm{Rh} / \mathrm{ZrO}_{2}$ and $5 \mathrm{wt} \% \mathrm{Rh} / \mathrm{SiO}_{2}$ catalysts. Reaction condition: $9.85 \mathrm{sccm}$ of $91 \% / 0.3 \% / 8.7 \% \mathrm{CH}_{4} / \mathrm{O}_{2} / \mathrm{N}_{2}, 260{ }^{\circ} \mathrm{C}$ atmospheric pressure, and catalyst $0.15 \mathrm{~g}$. Reproduced with permission from [30]. Copyright 2017 American Chemical Society.

$\mathrm{Cu} /$ ZSM-5 have been intensively studied in $\mathrm{CH}_{4}$ partial oxidation, and the bis( $\mu$ oxo)dicopper site, $\left[\mathrm{Cu}_{2}(\mu-\mathrm{O})_{2}\right]^{2+}$, was firstly identified as the active site, evidenced from the absorption band at $22,700 \mathrm{~cm}^{-1}$ in UV-Visible spectra [32,80]. Later, the active species in $\mathrm{Cu} / \mathrm{ZSM}-5$ catalyst was further ascribed to a bent mono- $(\mu$-oxo $)$ dicupric site, $\left[\mathrm{Cu}_{2}(\mu-\right.$ $\mathrm{O})]^{2+}$. DFT calculation and normal coordinate analysis of symmetric and anti-symmetric vibrations on resonance enhanced Raman spectroscopy provides insight into how the constrained lattice of ZSM-5 restricts the coordination environment of the bound $\mathrm{Cu}$ atoms and their spatial orientation in the formation of active sites for DOMTM [81,82]. This mono( $\mu$-oxo)dicopper core can be formed by activation in both $\mathrm{N}_{2} \mathrm{O}$ and $\mathrm{O}_{2}$ atmosphere as evidenced by observation of the UV-Vis NIR band at $22,700 \mathrm{~cm}^{-1}$ [83]. Additionally, the existence of trinuclear active species, $\left[\mathrm{Cu}_{3}(\mu-\mathrm{O})_{3}\right]^{2+}$, has been demonstrated and this trinuclear species in the non-frame-work of the zeolite structure is indeed more stable than the binuclear in the MFI zeolite framework indicated by DFT [84]. In general, the composition and varying topology of copper-modified zeolites are thought to have a large effect on the nature of active sites and on the performance in terms of $\mathrm{CH}_{3} \mathrm{OH}$ yield. Higher Si:Al ratios with highly dispersed $\mathrm{Al}$ atoms on copper-modified zeolites are more likely to support monomeric active sites, whereas lower Si:Al ratios are likely to stabilize multinuclear copper clusters due to the close proximity of $\mathrm{Al}$ atoms on zeolites [85]. 
A

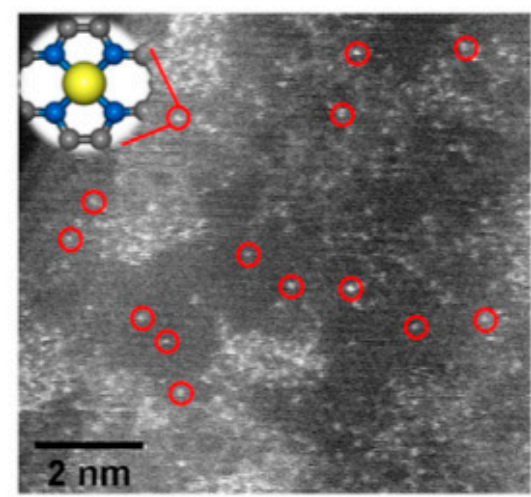

C

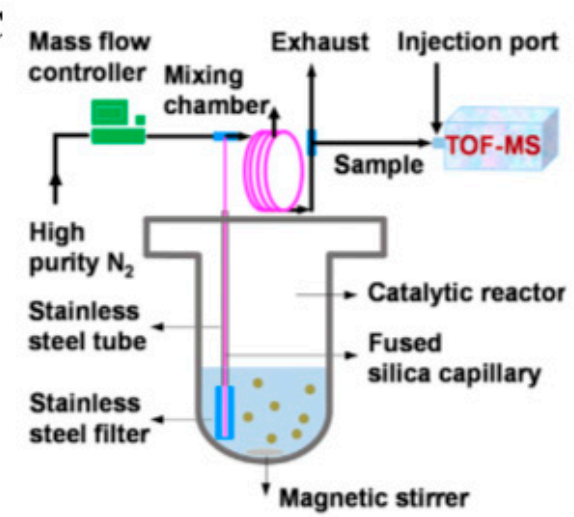

$\mathbf{E}$
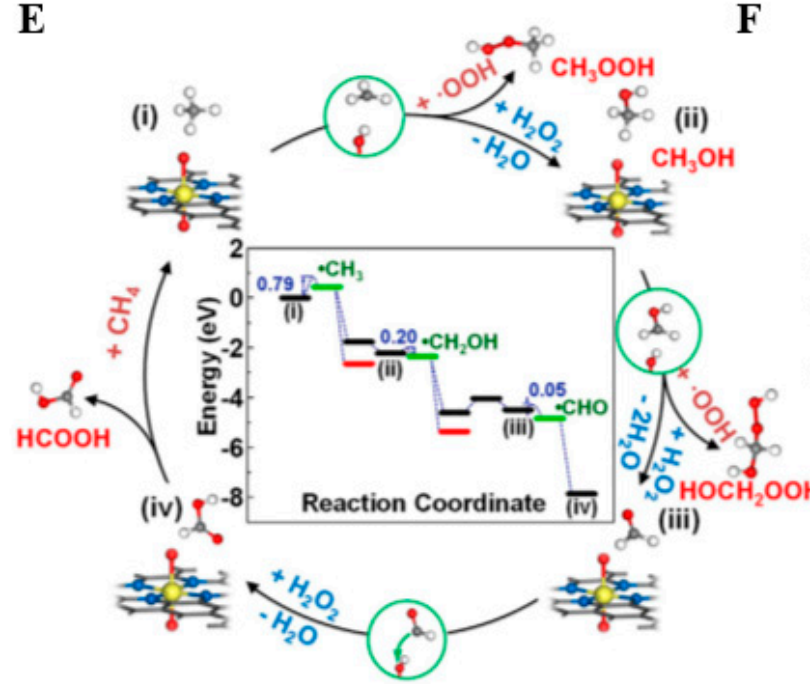

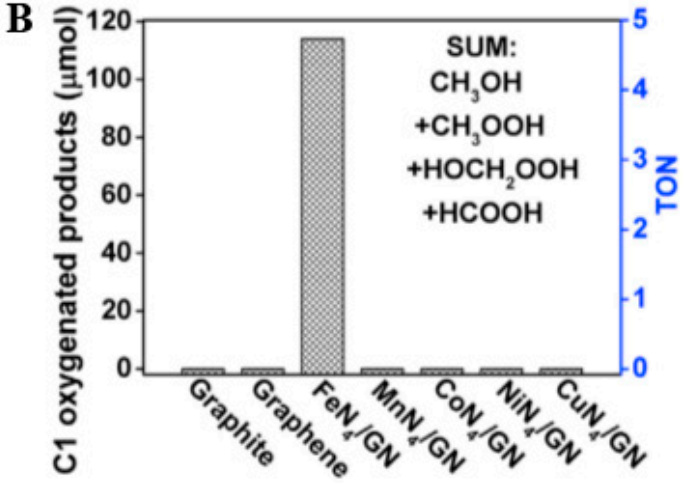

D



$\mathbf{F}$

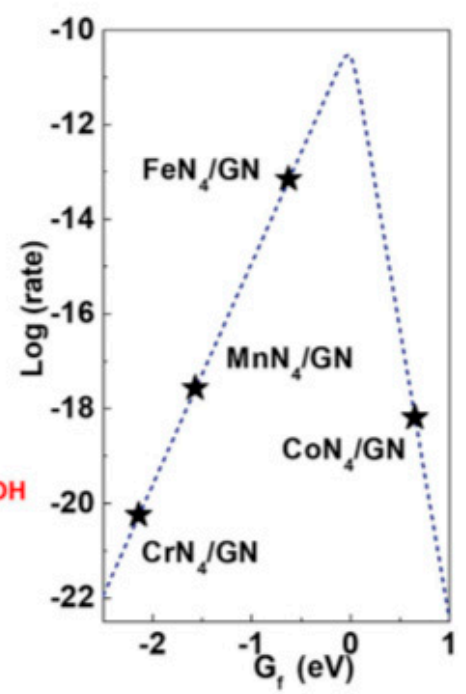

Figure 12. (A) High-angle annular dark-field scanning transmission electron microscopy (HAADFSTEM) image of $\mathrm{FeN}_{4} / \mathrm{GN}$ with the model of $\mathrm{FeN}_{4} / \mathrm{GN}$ in the upper left. (B) Different catalysts for $\mathrm{CH}_{4}$ oxidation at $25{ }^{\circ} \mathrm{C}$. (C) Scheme of operando TOF-MS online connected with high-pressure reactor. (D) Possible reaction path for $\mathrm{CH}_{4}$ oxidation over $\mathrm{FeN}_{4} / \mathrm{GN}$ catalyst. (E) Reaction pathway of $\mathrm{CH}_{4}$ conversion to $\mathrm{CH}_{3} \mathrm{OH}, \mathrm{CH}_{3} \mathrm{OOH}, \mathrm{HOCH} \mathrm{H}_{2} \mathrm{OOH}$ and $\mathrm{HCOOH}$ (the energy of reaction initiation was set as $0 \mathrm{eV}$ ) as well as reactants (black), intermediates (blue), products (green and red) and the activation energy of each step (unit, eV). (F) The relationship between $\mathrm{CH}_{4}$ activation rate ( $\log \left[\right.$ rate]) and formation energy of the $\mathrm{O}-\mathrm{MN}_{4}-\mathrm{O}$ active site (Gf) presents a volcano curve. The Gf and activation rate of the calculated $\mathrm{O}-\mathrm{CrN}_{4}-\mathrm{O}, \mathrm{O}-\mathrm{MnN}_{4}-\mathrm{O}, \mathrm{O}-\mathrm{FeN}_{4}-\mathrm{O}$, and $\mathrm{O}-\mathrm{CoN}_{4}-\mathrm{O}$ structures are shown on the volcano marked by black stars. Reproduced with permission from [10]. Copyright 2018 Cellpress. 


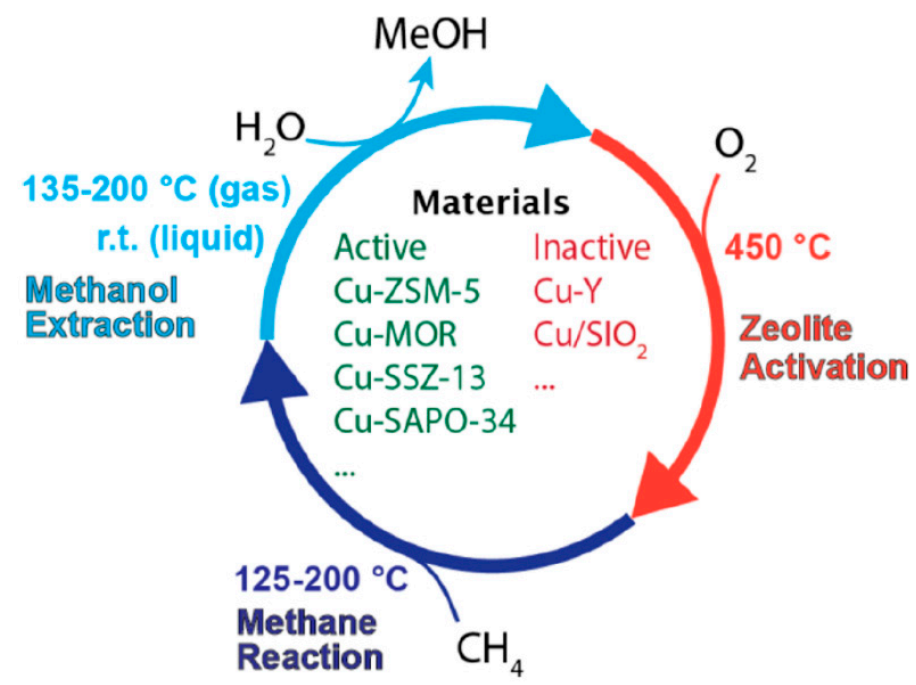

Figure 13. Scheme of stoichiometric chemical looping of $\mathrm{CH}_{4}$ to $\mathrm{CH}_{3} \mathrm{OH}$. Reproduced with permission from [79]. Copyright 2017 American Chemical Society.<smiles>[GeH2]O[GeH2]O[Te]</smiles><smiles>[AlH2]OOOC[Te+]</smiles><smiles>OCCCCC[TeH+]</smiles><smiles>CCO[18OH]</smiles>

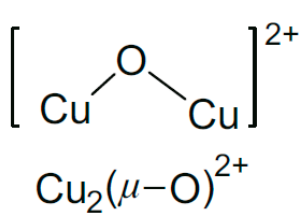

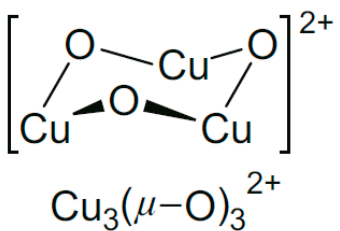

Figure 14. $\mathrm{Cu}$-oxo complexes proposed as the active sites for $\mathrm{CH}_{4}$ activation in $\mathrm{Cu}$-containing zeolites. Reproduced with permission from [80]. Copyright 2016 Elsevier.

$\mathrm{Cu}-\mathrm{MOR}$ is typically observed to produce a higher $\mathrm{CH}_{3} \mathrm{OH}$ yield than $\mathrm{Cu} / \mathrm{ZSM}-5$, but more than one site is responsible for $\mathrm{CH}_{3} \mathrm{OH}$ formation. $\mathrm{Cu} / \mathrm{MOR}$ has been suggested to possess both binuclear and trinuclear clusters capable of performing $\mathrm{CH}_{4}$ partial oxidation $[84,86,87]$. Whereas a binuclear active site in $\mathrm{Cu} / \mathrm{ZSM}-5$ is located in the intersection of the two ten-member-rings, $\mathrm{Cu}-\mathrm{MOR}$ provides two distinct local structures, situated in the eight-member-ring windows of the side pockets, suggested by spectroscopic observations and DFT simulations [88]. The improved performance in reactivity can be ascribed to subtle difference in the ground states of the $\mathrm{Cu}-\mathrm{O}-\mathrm{Cu}$ sites, indicating the participation of the zeolite lattice in the reaction coordinate. In addition, operando X-ray absorption spectroscopy (XAS) and high-energy-resolution fluorescence-detected (HERFD) and XANES spectroscopy provide a novel perspective on the complex nature and dynamics of $\mathrm{Cu}$-species present in the MOR framework, which enabled an accurate quantification of $\mathrm{Cu}$-speciation on zeolites [33]. The results demonstrated that the productivity increases with a slope of exactly 0.5 when the spectroscopically-determined concentration of active $\mathrm{Cu}$ is increased, across a series of materials and activation protocols, suggesting the active site on $\mathrm{Cu}$-mordenite for selective $\mathrm{CH}_{4}$ oxidation is a dicopper site (Figure 15). The proportion of active $\mathrm{Cu}$ in $\mathrm{Cu}-\mathrm{MOR}$ has been quantified by a spectroscopic method and correlated with reaction performance, and the highest $\mathrm{CH}_{3} \mathrm{OH}$ yield $\left(170 \mu \mathrm{mol}_{\mathrm{MeOH}} \mathrm{g}_{\mathrm{cat}}{ }^{-1}\right)$ has been achieved over $\mathrm{Cu}-\mathrm{MOR}$ with $\mathrm{Si}: \mathrm{Al}=7$ and $\mathrm{Cu}: \mathrm{Al}=0.18$ [33]. 

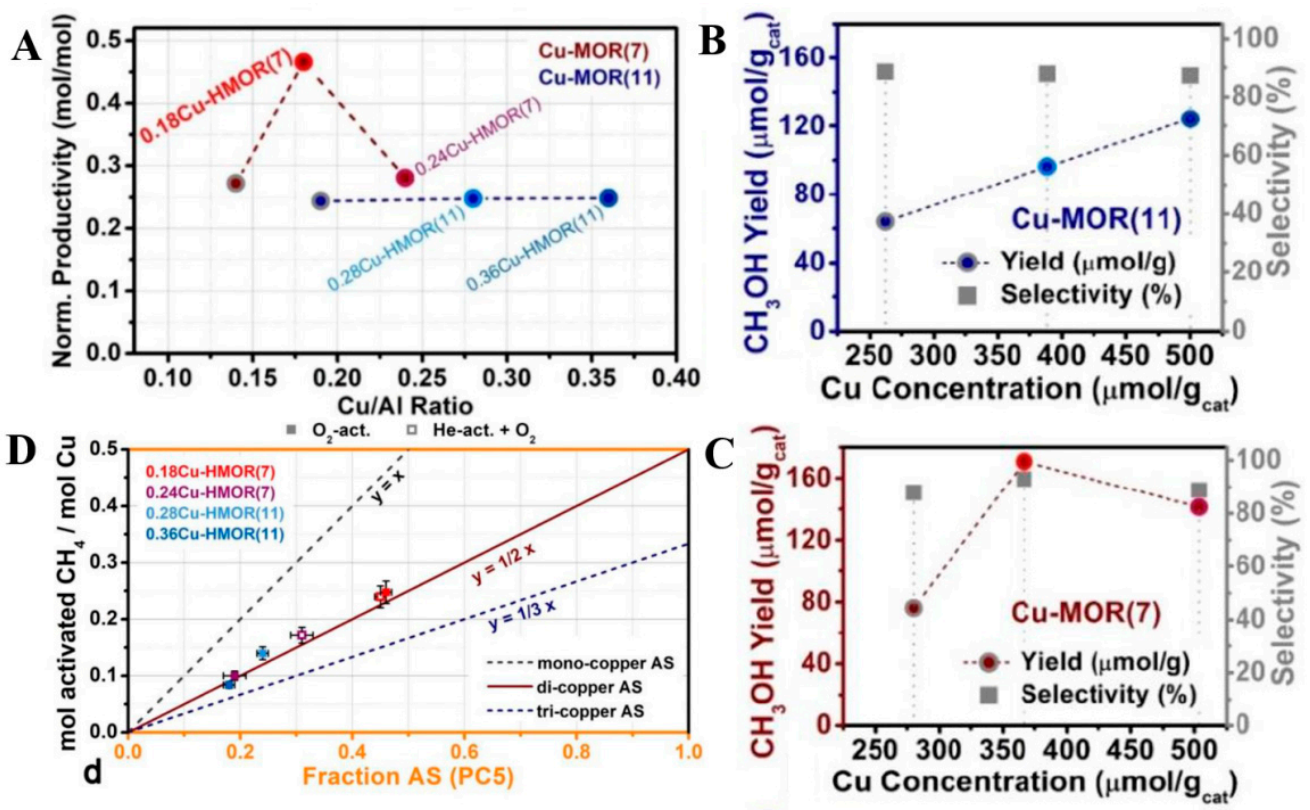

Figure 15. (A) Normalized productivity $\left(\mathrm{mol} \mathrm{CH}_{3} \mathrm{OH} / \mathrm{mol} \mathrm{Cu}\right)$ as a function of the $\mathrm{Cu}: \mathrm{Al}$ ratio, comparing the $\mathrm{Cu} / \mathrm{MOR}(7)$ and $\mathrm{Cu} / \mathrm{MOR}(11)$ series. $(\mathbf{B}, \mathbf{C}) \mathrm{CH}_{3} \mathrm{OH}$ yield and selectivity as a function of $\mathrm{Cu}$ concentration $\left(\mu \mathrm{mol} \mathrm{Cu} / \mathrm{g}_{\text {cat. }}\right.$ ) for $\mathrm{Cu}-\mathrm{MOR}$ materials with $\mathrm{Si}: \mathrm{Al}=7$ (B, $\mathrm{Cu} / \mathrm{MOR}(7)$ series $)$ and $\mathrm{Si}: \mathrm{Al}=11$ (C, Cu/MOR(11) series). (D) Quantitative correlation between the normalized productivity evaluated at the HERFD XANES testing conditions and the fraction of LT redox-inert fw- $\mathrm{Cu}^{\mathrm{II}}$ from linear combination fit analysis $\left(\mathrm{O}_{2}\right.$-activation: full colored symbols; He activation $+\mathrm{O}_{2}$ : empty colored symbols). All the experimentally determined values match the ideal trend line for stoichiometric conversion over a dicopper active site, reported as a full dark red line. Reprinted with permission from [33]. Copyright 2018 American Chemical Society.

Different framework topologies of $\mathrm{Cu}$-zeolites have been studied in stepwise partial oxidation of $\mathrm{CH}_{4}$ to $\mathrm{CH}_{3} \mathrm{OH}$, and $\mathrm{Cu}^{2+}$ ion-exchanged zeolite omega with MAZ type showed the highest yield $\left(86 \mu \mathrm{mol} \cdot \mathrm{g}_{\text {cat. }}{ }^{-1}\right.$ ) among these zeolite materials. Further experimental results revealed the highest $\mathrm{CH}_{3} \mathrm{OH}$ yield ever reported (i.e., $150 \mu \mathrm{mol} \mathrm{CH} \mathrm{CH}_{3} \mathrm{OH}$ per gram zeolite under 1 bar $\mathrm{CH}_{4}$, and as high as $200 \mu \mathrm{mol} \mathrm{CH}_{3} \mathrm{OH}$ per gram zeolite under 30 bar $\mathrm{CH}_{4}$ were achieved on copper-exchanged omega (MAZ) zeolite) $[35,86]$. The remarkable $\mathrm{CH}_{3} \mathrm{OH}$ yield of $\mathrm{Cu}$-omega is attributed to the relatively high density of copper-oxo active species formed on three-dimensional eight-member-ring channels. Additionally, highly dispersed $\mathrm{Cu}^{2+}$ ions in the zeolite pores are essential, which depends on the Si:Al ratio and the preparation method. Higher activation temperature leads to the formation of more copper oxo species, whereas too much copper is not favorable for $\mathrm{CH}_{3} \mathrm{OH}$ synthesis [86]. Copper-modified small pore zeolites, including SSZ-13, Cu/SSZ-16, $\mathrm{Cu} / \mathrm{SSZ}-39$, and $\mathrm{Cu} / \mathrm{SAPO}-34$, have been reported for DOMTM, and the improved $\mathrm{CH}_{3} \mathrm{OH}$ yield is attributed in part to the high-temperature water vapor extraction protocol [89]. In particularly, $\mathrm{Cu} / \mathrm{SSZ}-13$ could produce competitive quantities of $\mathrm{CH}_{3} \mathrm{OH}$ per copper atom, with the highest $\mathrm{CH}_{3} \mathrm{OH}$ yield of $125 \mu \mathrm{mol}_{\mathrm{MeOH}} \mathrm{g}_{\text {cat }}{ }^{-1}(0.2 \mathrm{~mol} \mathrm{CH} 3 \mathrm{OH} / \mathrm{mol} \mathrm{Cu})$ [34]. Optimal $\mathrm{CH}_{3} \mathrm{OH}$ productivity is correlated with optimal reducibility of $\mathrm{Cu} / \mathrm{SSZ}-13$, which is highly dependent on the composition, in terms of Si:Al and $\mathrm{Cu}: \mathrm{Al}$ ratios (Figure 16). Intermediate Si:Al ratios $(\sim 12-15)$ and high $\mathrm{Cu}$ loading $(\sim 0.5)$ are prone to produce a high population of $\mathrm{Z}\left[\mathrm{Cu}^{\mathrm{II}} \mathrm{OH}\right]$ precursor sites stabilized within an $8 \mathrm{MR}$ CHA zeolite, ultimately resulting in high $\mathrm{CH}_{3} \mathrm{OH}$ yields. The combination of testing and XAS measurements clearly evidence a positive linear correlation between the $\mathrm{CH}_{3} \mathrm{OH}$ productivity and the reducibility of the $\mathrm{Cu}$ centers. 


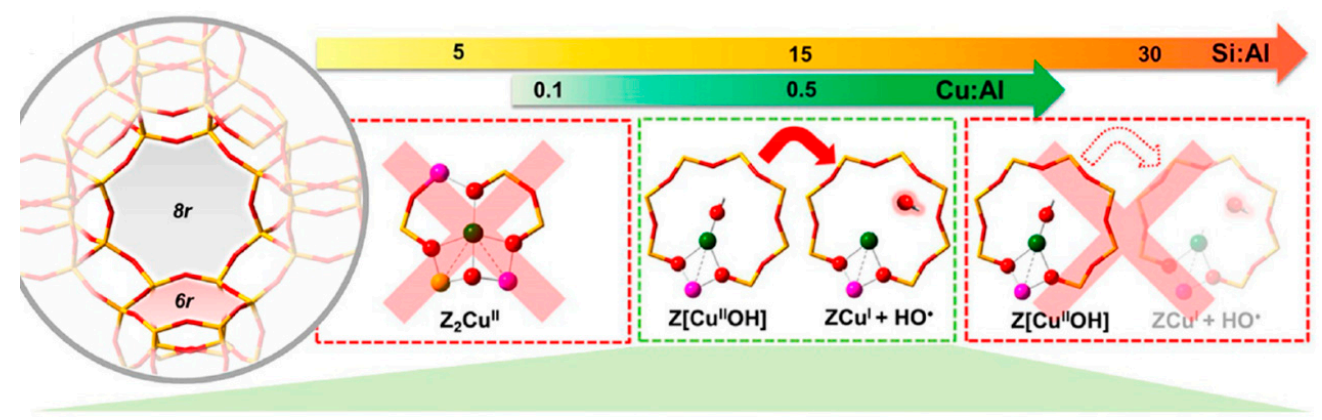

Figure 16. Rationalization of the effect of composition ( $\mathrm{Cu}: \mathrm{Al}$ and $\mathrm{Si}: \mathrm{Al}$ ratios) on the productivity for DOMTM over Cu/SSZ-13, reported as a full dark red line. Reprinted with permission from [34]. Copyright 2017 American Chemical Society.

The isothermal conditions were proposed to avoid the time-consuming heating and cooling step during the stepwise cycles. Several studies have shown the ability to run this reaction in an isothermal regime using $\mathrm{O}_{2}$ or $\mathrm{NO}$ as oxidant at 473 and $423 \mathrm{~K}$, respectively [90-92]. By operated in an isothermal regime, $\mathrm{Cu}$-FAU realized a stable $\mathrm{CH}_{3} \mathrm{OH}$ yield of $90 \mu \mathrm{mol} / \mathrm{g}$ and $92 \%$ selectivity at $633 \mathrm{~K}$ and ambient pressure without suffering long cycling time and temperature swing [92]. Furthermore, increasing the $\mathrm{CH}_{4}$ pressure to 15 bar results in a $\mathrm{CH}_{3} \mathrm{OH}$ yield of $360 \mu \mathrm{mol} / \mathrm{g}$, which is the highest value achieved over copper-exchanged zeolite in one cycle. The redox properties of $\mathrm{Cu}^{\mathrm{II}}$-oxo species vary with the structure of the sites, exhibiting different reduction temperature for copper-oxo aggregates and isolated sites, which is an important factor for $\mathrm{CH}_{3} \mathrm{OH}$ yield and selectivity. High reduction temperature leads to low activity and $\mathrm{CH}_{3} \mathrm{OH}$ yield, while a low copper oxo reduction temperature may tend to high activity toward $\mathrm{CH}_{4}$ conversion, but with low $\mathrm{CH}_{3} \mathrm{OH}$ selectivity. This connection between structure and reducibility of the copper-oxo species can be considered for further designing of high-performance catalysts on DOMTM at desired temperature.

Except $\mathrm{Cu}$-exchanged zeolites, some other catalysts (e.g., Fe-, Co- and Ni-exchanged zeolites) have been reported in both spectroscopy and computational studies based on $\mathrm{O}_{2}$ or $\mathrm{N}_{2} \mathrm{O}$ as oxidants. Co-based catalysts for DOMTM were determined in chemical looping mode analogue to the system with Cu-based catalysts [36,93]. Co/ZSM-5 can realize $\mathrm{CH}_{4}$ oxidation to oxygenates at low temperature by air as oxidant. Two catalyst preparation methods were adopted to tune the catalytic activity and selectivity of the catalytic system. The samples by ion-exchange are selective towards $\mathrm{CH}_{2} \mathrm{O}$, while impregnated samples with more oxidic cobalt species $\left(\mathrm{CoO}\right.$ and $\left.\mathrm{Co}_{3} \mathrm{O}_{4}\right)$ are favorable for $\mathrm{CH}_{3} \mathrm{OH}$ synthesis [94]. $\mathrm{Zn}$-promoted $\mathrm{Cu}$-containing mordenite was investigated using $\mathrm{O}_{2}$ as oxidant for DOMTM, and it was observed that $\mathrm{Zn}$ addition decreased the $\mathrm{CH}_{3} \mathrm{OH}$ yield first, followed by a gradual increase upon higher $\mathrm{Zn}$ concentration. The promotional effects of $\mathrm{Zn}$ addition could be attributed to the fact that is catalytically active by itself, and to promoting $\mathrm{O}_{2}$ activation by small $\mathrm{ZnO}$ particles [95].

An inverse $\mathrm{CeO}_{2} / \mathrm{Cu}_{2} \mathrm{O} / \mathrm{Cu}(111)$ catalyst was reported that can activate $\mathrm{CH}_{4}$ to produce $\mathrm{C}, \mathrm{CH}_{\mathrm{X}}$ fragments, and $\mathrm{CO}_{\mathrm{X}}$ species at room temperature. The addition of water had a strong effect on $\mathrm{CH}_{3} \mathrm{OH}$ synthesis by DOMTM (Figure 17), mainly due to $\mathrm{OH}$ groups formed by the dissociation of water on the catalyst surface, which could adsorb easily on the active sites with special electronic properties, and thus inhibit the $\mathrm{CH}_{X}$ full decomposition [96]. A further study showed that the site blocking effect of water on $\mathrm{Ni} / \mathrm{CeO}_{2}$ catalyst can improve the $\mathrm{CH}_{3} \mathrm{OH}$ selectivity, in which the production of $\mathrm{CO}$ and $\mathrm{CO}_{2}$ are inhibited [39]. Another factor that needs to be considered is the effect of metal-support interaction to bind and activate $\mathrm{CH}_{4}$ and $\mathrm{H}_{2} \mathrm{O}$, which provides a new insight for designing metal/oxide catalysts for DOMTM. 


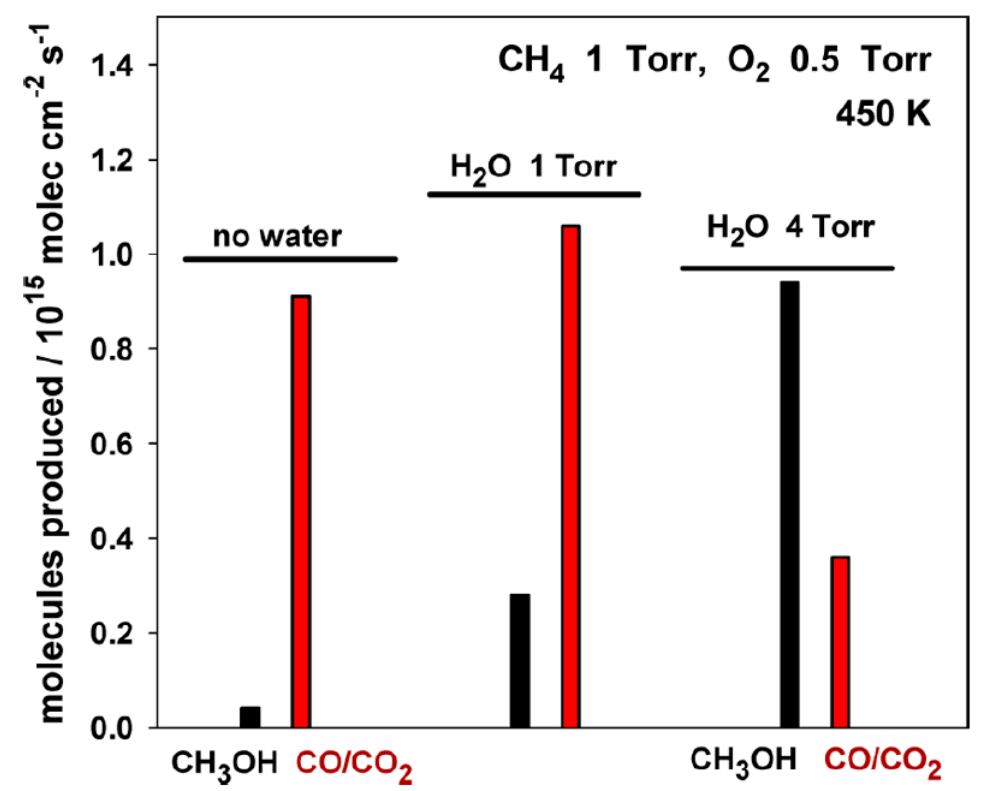

Figure 17. Production of $\mathrm{CH}_{3} \mathrm{OH}$ and $\mathrm{CO} / \mathrm{CO}_{2}$ as a function of water pressure on a $\mathrm{CeO}_{2} / \mathrm{Cu}_{2} \mathrm{O} / \mathrm{Cu}(111)$ catalyst in which $\sim 40 \%$ of the $\mathrm{Cu}_{2} \mathrm{O}$ was covered by ceria. The samples were exposed to 1 Torr of $\mathrm{CH}_{4}, 0.5$ Torr of $\mathrm{O}_{2}$ and 0,1 , or 4 Torr of $\mathrm{H}_{2} \mathrm{O}$ at $450 \mathrm{~K}$ in a batch reactor. Reprinted with permission from [96]. Copyright 2016 American Chemical Society.

$\mathrm{O}_{2}$ as oxidant has been intensively studied during the past decades, and many catalysts has been explored in DOMTM under low temperature and atmosphere pressure. Recently, the economic potential and guidance have been reported on DOMTM via a chemical looping (or redox) process by comparison with the industrial performance criteria [97]. Low $\mathrm{CH}_{3} \mathrm{OH}$ productivity and long cycle time lead to an overall production rate that is a factor of $\sim 50$ below the industrial threshold; therefore, enhancing productivity and reducing the cycle time are highly recommended for future studies.

\subsection{Water as Oxidant or Co-Oxidant}

The oxidizing character of water $\left(\mathrm{H}_{2} \mathrm{O}\right)$ is weak and; therefore, its use has been rarely reported for DOMTM (4), since it is a strong endothermic reaction.

$$
\mathrm{CH}_{4}+\mathrm{H}_{2} \mathrm{O} \rightarrow \mathrm{CH}_{3} \mathrm{OH}+\mathrm{H}_{2} \quad \Delta \mathrm{H}(298 \mathrm{~K})=262.2 \mathrm{~kJ} \cdot \mathrm{mol}^{-1}
$$

Van Bokhoven and co-workers proposed a direct stepwise method for DOMTM over a copper-containing zeolite, based on $\mathrm{H}_{2} \mathrm{O}$ as an oxidant [98,99]. Firstly, $\mathrm{Cu}-\mathrm{MOR}$ was activated at $673 \mathrm{~K}$ with helium (Figure 18, Top), and then exposed to 7 bars of $\mathrm{CH}_{4}$, and finally reacting with $\mathrm{H}_{2} \mathrm{O}$ at $473 \mathrm{~K}$. Noticeably, both $\mathrm{CH}_{3} \mathrm{OH}$ selectivity and yield remained constant over three additional cycles; the $\mathrm{CH}_{3} \mathrm{OH}$ productivity stabilized at $0.202 \mathrm{~mol}_{\mathrm{CH} 3 \mathrm{OH}} / \mathrm{mol}_{\mathrm{Cu}}$, and the selectivity reached $97 \%$. In this anaerobic process, $\mathrm{H}_{2} \mathrm{O}$ as the source of oxygen can regenerate the zeolite active centers and ensures energetically favorable desorption of $\mathrm{CH}_{3} \mathrm{OH}$. An excess of $\mathrm{H}_{2} \mathrm{O}$ can stabilize the reaction intermediates, indicated by isotopic labeling and DFT calculation. The reaction pathway predicted by DFT is illustrated in Figure 18, and the proposed mechanism shows that $\mathrm{CH}_{4}$ oxidation occurs at $\mathrm{Cu}^{\mathrm{II}}$ oxide active centers, followed by $\mathrm{Cu}^{\mathrm{I}}$ reoxidation by $\mathrm{H}_{2} \mathrm{O}$ with the formation of $\mathrm{H}_{2}$ [98]. Further insight of the active sites structure has been studied on Cu-MOR [86,100]. Monomeric and oligomeric $\mathrm{Cu}$ active sites were synthesized by mordenite with varied Si:Al ratio. Copper oligomer species shows a high activity under both aerobic $\left(\mathrm{O}_{2}\right.$ as oxidant $)$ and anaerobic $\left(\mathrm{H}_{2} \mathrm{O}\right.$ as oxidant) activation conditions, whereas copper monomer sites produce $\mathrm{CH}_{3} \mathrm{OH}$ only in the aerobic process. This difference is most possibly associated with the stabilization effect of the $\mathrm{H}_{2} \mathrm{O}$ molecules on active copper sites [86]. Furthermore, $\mathrm{Cu}$ (II)exchanged mordenites (i.e., $\mathrm{Cu} / \mathrm{H}-\mathrm{MOR}$ and $\mathrm{Cu} / \mathrm{Na}-\mathrm{MOR}$ ) were compared with varied 
Si:Al ratio and $\mathrm{Cu}: \mathrm{Al}$ ratio, and the results exhibited $\mathrm{Cu} / \mathrm{H}-\mathrm{MOR}$ had a higher methanol yield, which contributed to suppression of $\mathrm{CO}_{2}$ formation from the methoxy species at the final oxidation step indicated by DFT calculation [100]. Additionally, the activity of $\mathrm{Cu}-\mathrm{MOR}$ is in line with the amount of Brønsted acid sites in the catalysts on DOMTM oxidized by $\mathrm{H}_{2} \mathrm{O}$. Inspired by the study of anaerobic process on methane oxidation on $\mathrm{Cu} / \mathrm{MOR}$, other catalyst, e.g., $\mathrm{Cu} / \mathrm{SSZ}-13$, was also studied in a continuous flow reactor at ambient pressure and low temperature $\left(\leq 250{ }^{\circ} \mathrm{C}\right)$ [101]. Undoubtedly, the DOMTM process with $\mathrm{H}_{2} \mathrm{O}$ as oxidant demonstrated here is promising from the perspective of cost and local on-site applications, which may contribute to the development of an industrial process for DOMTM. However, this work has also given rise to several discussions among researchers, mainly on several technical comments and replies questioning and defending the thermodynamic feasibility of the proposed mechanisms [98,102-104].

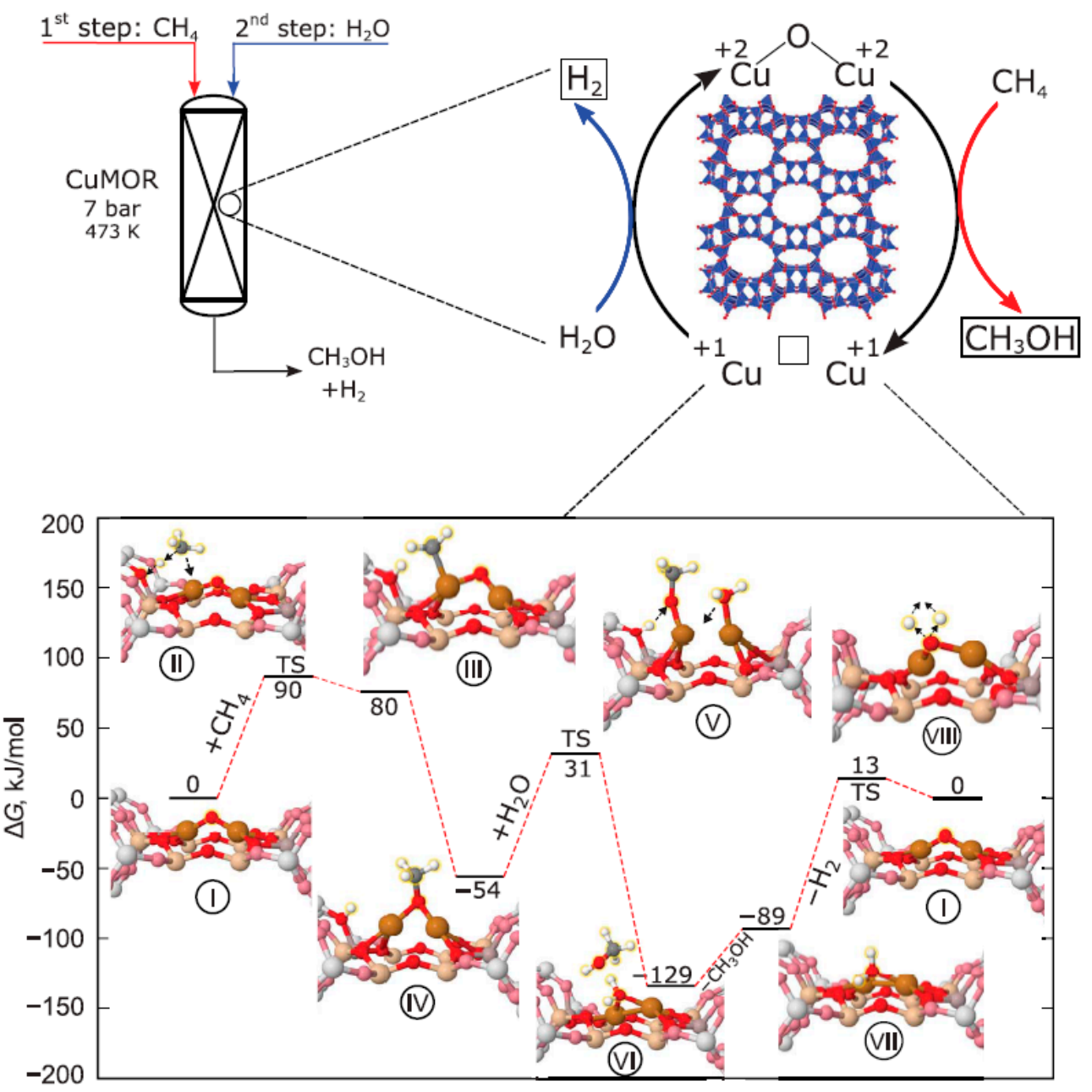

Figure 18. Mechanism of partial oxidation of $\mathrm{CH}_{4}$ using $\mathrm{H}_{2} \mathrm{O}$ as oxidant. (Top) Schematic representation of the reaction conditions of the partial oxidation of $\mathrm{CH}_{4}$ by $\mathrm{H}_{2} \mathrm{O}$, involving the reduction of the dicopper site of mordenite and providing two electrons to stoichiometrically oxidize $\mathrm{CH}_{4}$ into $\mathrm{CH}_{3} \mathrm{OH}$. Subsequent reduction of $\mathrm{H}_{2} \mathrm{O}$ into $\mathrm{H}_{2}$ returns two electrons for the rejuvenation of the mono(m-oxo) dicopper active core. (Bottom) Reaction pathway predicted by DFT, illustrating the thermodynamic $(\Delta G$, change in Gibbs free energy) and kinetic feasibility of the proposed mechanism. Reprinted with permission from [98]. Copyright 2017 American Association for the advancement of science.

Except for $\mathrm{H}_{2} \mathrm{O}$ as a sole oxidant, the $\mathrm{H}_{2} \mathrm{O}$-promoted DOMTM process exhibits a big potential to improve the $\mathrm{CH}_{3} \mathrm{OH}$ productivity and selectivity $[38,39,87,95,105-107]$. Recently, a $\mathrm{CeO}_{2} / \mathrm{Cu}_{2} \mathrm{O} / \mathrm{Cu}(111)$ catalyst was reported for which the reaction can be 
operated using a mixture of $\mathrm{CH}_{4}, \mathrm{O}_{2}$ and $\mathrm{H}_{2} \mathrm{O}$ as feedstock. $\mathrm{H}_{2} \mathrm{O}$ participated in the reaction as the actual oxygen provider and enabled direct $\mathrm{CH}_{4}$ to $\mathrm{CH}_{3} \mathrm{OH}$ conversion. Additionally, $\mathrm{H}_{2} \mathrm{O}$ can act as a site blocker, where the facile dissociation at the interfacial Ce sites produced the active ${ }^{*} \mathrm{OH}$, which promotes the DOMTM process [38]. Furthermore, $\mathrm{H}_{2} \mathrm{O}$ also functions as an extractor in the hydrogenation of ${ }^{*} \mathrm{CH}_{3} \mathrm{O}$ or blocks surface sites to preventing its decomposition, thus facilitating the extraction of $\mathrm{CH}_{3} \mathrm{OH}[39,95]$.

In this section, we showed the latest progress of different oxidants $\left(\mathrm{N}_{2} \mathrm{O}, \mathrm{H}_{2} \mathrm{O}_{2}, \mathrm{O}_{2}\right.$, and $\mathrm{H}_{2} \mathrm{O}$ ) for DOMTM in heterogeneous catalysis. Attempts on how to reduce the kinetic energy barrier (Ea) of DOMTM are key to improve the $\mathrm{CH}_{4}$ conversion and $\mathrm{CH}_{3} \mathrm{OH}$ productivity, by using suitable oxidants. Generally, strong oxidants result in a lower Ea and lower reaction temperature. However, this is not always true, because different catalysts reduce the Ea to different degrees. Furthermore, most Ea values for DOMTM have been obtained by DFT calculations, but they are subject to uncertainties (e.g., due to the used functionals and dispersion corrections). Therefore, unified methods and standards need to be established to compare the role of catalysts in reducing the Ea of DOMTM. Recently, $\mathrm{RuCu}$ nano-sheets were reported on which $\mathrm{CH}_{4}$ can be efficiently converted to $\mathrm{CH}_{3} \mathrm{OH}$ and $\mathrm{CH}_{3} \mathrm{OOH}$ (methylhydroperoxide) under mild conditions in the presence of $\mathrm{O}_{2}$ and trace amount of $\mathrm{H}_{2} \mathrm{O}_{2}$ [40]. The combination of two or more oxidants (e.g., $\mathrm{O}_{2}+\mathrm{H}_{2} \mathrm{O}$, $\mathrm{O}_{2}+\mathrm{H}_{2} \mathrm{O}_{2}$ ) may be effective in lowering the energy barrier of $\mathrm{CH}_{4}$ oxidation in DOMTM, avoiding the over-oxidation of $\mathrm{CH}_{3} \mathrm{OH}$. Additionally, the exploration of efficient catalytic system remains a long-pursued target for DOMTM in heterogeneous catalysis.

\section{Plasma Catalysis}

Plasma catalysis provides an alternative to heterogeneous catalysis, where the catalytic process is complemented by plasma technology to activate the source gas [108-111]. This combination is often observed to result in a synergy between plasma and catalyst, which is increasingly gaining attention in many fields, such as $\mathrm{CO}_{2}$ and $\mathrm{CH}_{4}$ conversion, $\mathrm{NO}_{\mathrm{x}}$ decomposition, $\mathrm{NH}_{3}$ synthesis, $\mathrm{H}_{2} \mathrm{O}_{2}$ synthesis, Fischer-Tropsch synthesis, volatile organic compounds removal, wastewater treatment and degradation of pesticide residues [110-112]. Typically, the function of a catalyst in a given process is to reduce the activation energy barrier for the rate-limiting reaction and regulate the product distribution. This clear-cut function could also apply to plasma catalysis [113]. However, the effects of a catalyst in plasma catalysis are somewhat different than in traditional heterogeneous catalysis. In general, plasma as the "fourth state of matter" consists of many reactive species (i.e., electrons, molecules, radicals, excited species and ions), which could be adsorbed on the catalyst surface. The surface reactions happening in plasma catalysis are more complex than in conventional thermal catalysis and the possible interaction mechanisms between plasma and catalyst are illustrated in Figure 19 [113]. In this section, we mainly focus on the insights obtained by heterogeneous catalysis based on different oxidants for the further development of the emerging field of plasma catalysis for DOMTM.

The kind of plasma used in plasma catalysis is so-called non-thermal plasma (NTP), where the gas temperature remains near room temperature, while the temperature of the electrons is extremely high (usually in the range of $1-10 \mathrm{eV}$ ). This electron temperature is sufficient to activate stable gas molecules (e.g., $\mathrm{CH}_{4}, \mathrm{CO}_{2}$ and $\mathrm{O}_{2}$ ). Hence, NTP offers a distinct approach to enable thermodynamically unfavorable chemical reactions to proceed at low temperature by breaking thermodynamic limits [113-117]. The direct oxidation of $\mathrm{CH}_{4}$ in NTP seems a promising way of forming oxygenates (e.g., $\mathrm{CH}_{3} \mathrm{OH}$ or $\mathrm{CH}_{2} \mathrm{O}$ ). Activated by plasma, the neutral $\mathrm{CH}_{4}$ and $\mathrm{O}_{2}$ molecules can form reactive species, and the major dissociation intermediates are the $\mathrm{CH}_{3}$ radicals and $\mathrm{O}$ atoms [118]. As mentioned above, $\mathrm{CH}_{3} \mathrm{OH}$ is more reactive than $\mathrm{CH}_{4}$ and more likely to undergo oxidation; therefore, moderate conditions (i.e., low temperature) are suitable, which can be provided by NTP. There exist various types of plasmas, such as microwave discharges, glow discharges, gliding arc discharges and dielectric barrier discharges (DBD). The latter are particularly suitable for plasma catalysis, because of their simple operation (atmospheric pressure 
and near room temperature) and simple design, allowing the easy integration of catalysts in the plasma reactor [108,112], Thus plasma-driven DOMTM is mostly based on DBD plasmas, and recent reports have shown the prospect in $\mathrm{CH}_{4}$ conversion assisted by plasma technology. An overview of the representative results is summarized in Table 2. Noticeably, DOMTM by plasma catalysis mostly can be operated near room temperature. Hence, $\mathrm{H}_{2} \mathrm{O}_{2}$ is rarely reported as oxidant, due to its high boiling point $\left(150.2{ }^{\circ} \mathrm{C}\right)$. In addition, $\mathrm{CO}_{2}$ can be used as a soft oxidant for $\mathrm{CH}_{4}$ conversion in plasma catalysis (i.e., dry reforming of methane (DRM). This is not the focus of our review, as it has been elaborated in recent reviews $[119,120]$.

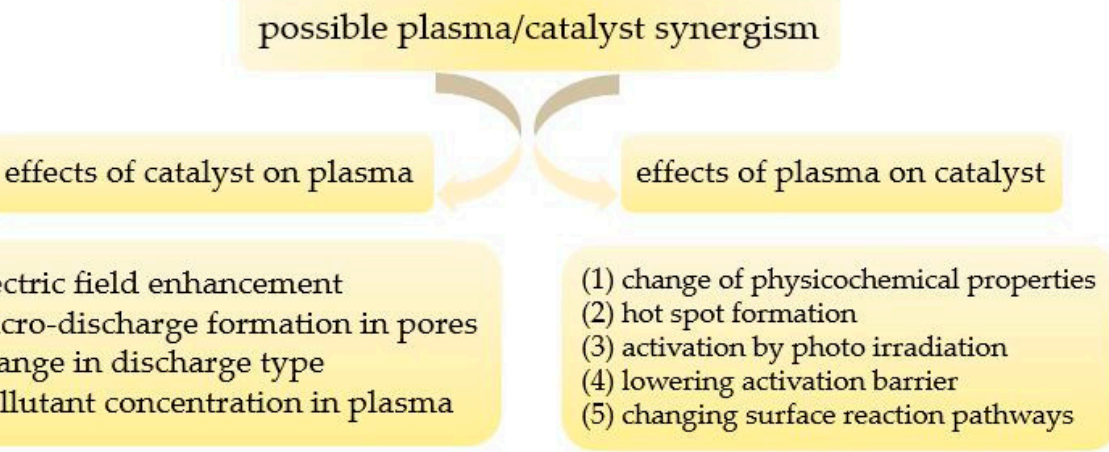

Figure 19. Overview of the various effects of catalyst on the plasma and of the plasma on the catalyst, which may give rise to a synergistic plasma-catalytic operation. Reproduced with permission from [113]. Copyright 2019 MDPI.

Table 2. Comparison of $\mathrm{CH}_{4}$ conversion and $\mathrm{CH}_{3} \mathrm{OH}$ selectivity in various plasma and plasma catalysis systems.

\begin{tabular}{|c|c|c|c|c|c|c|c|c|}
\hline System & Oxidant & Packed Material & Power (W) & $\begin{array}{c}\text { SEI } \\
(k J / L)^{a}\end{array}$ & $\begin{array}{l}\text { Temp. } \\
\text { (K) }\end{array}$ & $\begin{array}{c}\mathrm{CH}_{4} \\
\text { Conv. }(\%)\end{array}$ & $\begin{array}{l}\mathrm{CH}_{3} \mathrm{OH} \\
\text { Sel. (\%) }\end{array}$ & Ref. \\
\hline \multirow{9}{*}{$\begin{array}{c}\text { Plasma } \\
\text { only }\end{array}$} & $\mathrm{N}_{2} \mathrm{O}$ & / & $0.27-7.7$ & - & - & 5 & 43 & [121] \\
\hline & $\mathrm{N}_{2} \mathrm{O}$ & / & 6 & 6 & - & 15 & 31 & [122] \\
\hline & $\mathrm{N}_{2} \mathrm{O}$ & / & 6 & 6 & - & $<15$ & 28 & [123] \\
\hline & $\mathrm{O}_{2}$ & / & 5.7 & 3.4 & $\mathrm{RT}^{\mathrm{b}}$ & 1.9 & 47 & [124] \\
\hline & $\mathrm{O}_{2}$ & / & 1.7 & 3.4 & $\mathrm{RT}$ & 7 & 20 & [125] \\
\hline & $\mathrm{O}_{2}$ & / & 118 & 35.4 & 288 & 6 & 19 & [126] \\
\hline & $\mathrm{O}_{2}$ & / & 200 & 4.0 & 353 & 3 & 30 & [127] \\
\hline & Air & / & 400 & 11.9 & 353 & 15 & 13.3 & [127] \\
\hline & Air & / & 140 & 28 & 523 & $\sim 25$ & $\sim 8$ & [128] \\
\hline \multirow{9}{*}{$\begin{array}{c}\text { Plasma } \\
\text { catalysis }\end{array}$} & $\mathrm{N}_{2} \mathrm{O}$ & $\mathrm{Cu}-\mathrm{Ni} / \mathrm{CeO}_{2}$ & 6 & 6 & - & 23 & 36 & [122] \\
\hline & $\mathrm{O}_{2}$ & $\mathrm{Fe} / \gamma-\mathrm{Al}_{2} \mathrm{O}_{3}$ & 1.8 & 3.6 & $\mathrm{RT}$ & 13 & 36 & [118] \\
\hline & $\mathrm{O}_{2}$ & Glass Beads & 1.7 & 5.1 & - & 15.4 & 35.4 & [129] \\
\hline & $\mathrm{O}_{2}$ & $\mathrm{Cu} / \gamma-\mathrm{Al}_{2} \mathrm{O}_{3}$ & 1.9 & 3.6 & - & 9 & 37 & [130] \\
\hline & $\mathrm{O}_{2}$ & $\mathrm{Ga} / \mathrm{CZA}$ & 50 & / & - & 54.5 & 22.2 & [131] \\
\hline & $\mathrm{O}_{2}$ & $\mathrm{Ni} / \mathrm{YSZ}$ & 80 & 160 & $\mathrm{RT}$ & 35.3 & 23.5 & [132] \\
\hline & Air & $\mathrm{CuZn} / \mathrm{Al}_{2} \mathrm{O}_{3}$ & 1.7 & 3.4 & - & 11 & 28 & [133] \\
\hline & Air & $\mathrm{Fe}_{2} \mathrm{O}_{3}-\mathrm{CuO} / \mathrm{CP}$ & 140 & 28 & 473 & $\sim 26$ & 11 & [134] \\
\hline & Air & $\mathrm{Fe}_{2} \mathrm{O}_{3} / \mathrm{CuO} / \mathrm{Al}_{2} \mathrm{O}_{3}$ & 120 & 24 & 473 & 43 & 3.7 & [135] \\
\hline
\end{tabular}

${ }^{\text {a }}$ SEI: Specific energy input; ${ }^{\mathrm{b}}$ RT: Room temperature.

\subsection{Nitrous Oxide as an Oxidant}

Co-processing of $\mathrm{CH}_{4}$ and nitrous oxide into high-value products, like $\mathrm{CH}_{3} \mathrm{OH}, \mathrm{CH}_{2} \mathrm{O}$, etc., was attempted in plasma under ambient conditions [121-123,136]. In a DBD reactor, it was observed that the mole ratio of $\mathrm{CH}_{4} / \mathrm{N}_{2} \mathrm{O}$ significantly affected the conversion and the product selectivity, and the highest selectivity $(28 \%)$ of $\mathrm{CH}_{3} \mathrm{OH}$ could be realized at 5:1 $\mathrm{CH}_{4} / \mathrm{N}_{2} \mathrm{O}$ mole ratio, decreasing to $23 \%$ and $13 \%$, respectively, for $1: 1$ and 1: 5 ratios. 
A low ratio of $\mathrm{CH}_{4} / \mathrm{N}_{2} \mathrm{O}$ (i.e., 1:5) contains more $\mathrm{N}_{2} \mathrm{O}$ in the feed, which results in deep oxidation of the formed oxygenates to $\mathrm{CO}$ and $\mathrm{CO}_{2}$ [123]. Additionally, argon carrier gas played an important role in DOMTM for $\mathrm{CH}_{4} / \mathrm{N}_{2} \mathrm{O}$ plasma, by energy transfer from excited Ar atoms to the reactant molecules in this DBD system [121]. The formation of small amounts of $\mathrm{C}_{2} \mathrm{H}_{6}$ and carbonaceous materials was observed at higher input voltages, next to the main products *i.e., $\mathrm{CH}_{3} \mathrm{OH}, \mathrm{HCHO} \mathrm{H}, \mathrm{CO}$ and $\mathrm{CO}_{2}$ ). Under the conditions of $5 \% \mathrm{CH}_{4}$ and $5 \% \mathrm{~N}_{2} \mathrm{O}$ in $\mathrm{Ar}, 50 \mathrm{~cm}^{3} /$ min total flow rate and $7 \mathrm{kV}$ input voltage, the combined yield of $\mathrm{CH}_{3} \mathrm{OH}$ and $\mathrm{HCHO}$ reached $10 \mathrm{~mol} \%$, but a further rise in residence time led to a lower selectivity of $\mathrm{CH}_{3} \mathrm{OH}$ and $\mathrm{HCHO}$ [121].

In order to improve the selectivity to $\mathrm{CH}_{3} \mathrm{OH}, \mathrm{CuO}(10 \%) / \mathrm{CeO}_{2}, \mathrm{NiO}(10 \%) / \mathrm{CeO}_{2}$ and $\mathrm{Cu}-\mathrm{Ni}(5-5 \%) / \mathrm{CeO}_{2}$ catalysts were packed in a $\mathrm{DBD}$ reactor [122]. The catalytic activity followed the order of $\mathrm{CuO}-\mathrm{NiO} / \mathrm{CeO}_{2}>\mathrm{NiO} / \mathrm{CeO}_{2}>\mathrm{CuO} / \mathrm{CeO}_{2}$, with the best $\mathrm{CH}_{3} \mathrm{OH}$ selectivity of $\sim 36 \%$ on $\mathrm{NiO} / \mathrm{CeO}_{2}$ catalyst. The best performance is highly attributed to the oxygen vacancies (proven by Raman results), and the increasing amount of oxygen vacancies may facilitate oxygen transfer and improve the catalytic activity [122]. Generally, the generation of energetic electrons is considered as initial step in plasma-initiated reactions $[110,136]$. In the plasma zone, the presence of abundant electrons could active $\mathrm{NO}_{2}$ and $\mathrm{CH}_{4}$ into various radicals. Based on molecular modelling results, the energy barrier for the formation of formyl radical (HCO) is much lower than that of other species [136]. Therefore, the authors suggested that $\mathrm{HCO}$ as an intermediate could be the major reason for $\mathrm{CH}_{3} \mathrm{OH}$ production [136]. Subsequently, further $\mathrm{H}$ addition to form $\mathrm{CH}_{3} \mathrm{OH}$ was found to have a very low energy barrier. This investigation confirms that DOMTM with $\mathrm{NO}_{2}$ as oxidant in non-thermal plasma is a simple and effective way for $\mathrm{CH}_{3} \mathrm{OH}$ production. However, the competing reaction (Figure 20) producing toxic gas ( $\mathrm{HCN}$ and nitric acids) is a main challenge, although higher $\mathrm{CH}_{3} \mathrm{OH}$ selectivity can be obtained, compared with other oxidants (e.g., $\left.\mathrm{O}_{2}[136]\right)$.

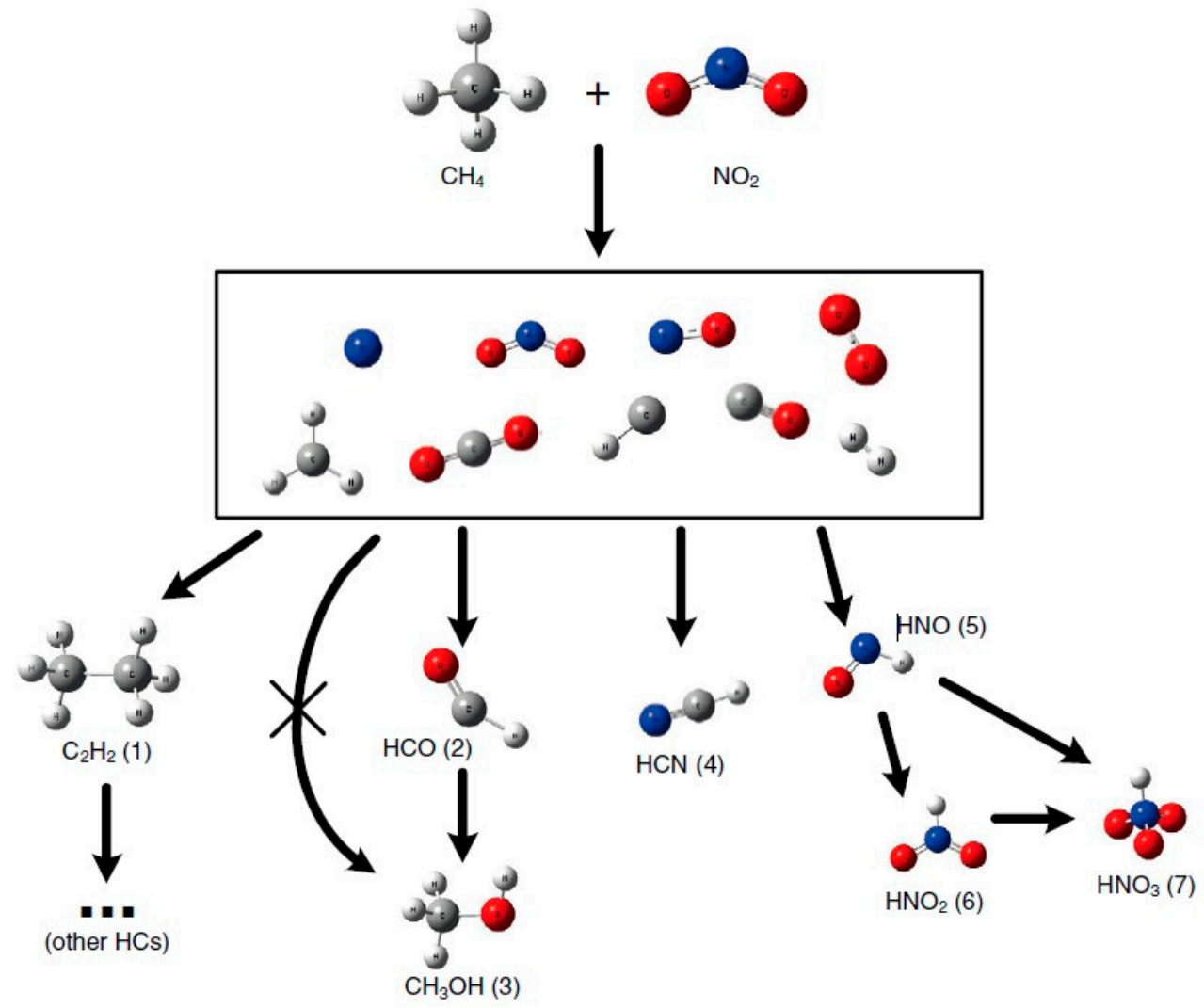

Figure 20. Schematic diagram of the products of $\mathrm{CH}_{4} / \mathrm{N}_{2} \mathrm{O}$ reaction using non-thermal plasma. Reproduced with permission from [136]. Copyright 2015 Elsevier. 


\subsection{Oxygen or Air as an Oxidant}

Molecular oxygen $\left(\mathrm{O}_{2}\right)$ could be a perfect oxidant for plasma catalysis, due to its low cost and lack of harmful by-products, so it can meet the industry's main goals in "green chemistry". In $\mathrm{CH}_{4} / \mathrm{O}_{2}$ or $\mathrm{CH}_{4}$ /air plasmas without catalyst, the effects of various parameters (e.g., reactor configuration, feed ratio, applied voltage, input power, residence time, pressure, specified energy input (SEI) and reactor wall temperature) have been extensively studied $[124,126,127,137-142]$. Oxidative products in these studies mainly included $\mathrm{CH}_{3} \mathrm{OH}, \mathrm{HCHO}, \mathrm{HCOOH}, \mathrm{CO}$ and $\mathrm{CO}_{2}$, and a small quantity of $\mathrm{C}_{2}{ }^{+}$oxygenates (e.g., ethanol, acetic acid and acetone). Noticeably, avoiding the decomposition of the produced $\mathrm{CH}_{3} \mathrm{OH}$ or other oxygenates by the plasma is an important issue [119].

Nozaki et al. reported a single step $\mathrm{CH}_{4}$ conversion into organic oxygenates by a microplasma reactor, and the organic oxygenates reached 5-20\% one-pass yield with $70-30 \%$ selectivity. Additionally, syngas was found to be the main product with selectivity of $40 \%$ [140]. A further study showed that $\mathrm{H}_{2} \mathrm{O}_{2}$ with concentration of $0.15 \mathrm{wt} . \%$ was also detected in the liquid products [141]. Methyl hydroperoxide $\left(\mathrm{CH}_{3} \mathrm{OOH}\right)$ was also detected by ${ }^{1} \mathrm{H}-\mathrm{NMR}$, and it was considered to be an important intermediate for plasma-assisted partial oxidation of $\mathrm{CH}_{4}$ [141]. The decomposition and further oxidation of liquid organic oxygenates cannot be ignored in plasma-assisted DOMTM. Larkin et al. adopted in situ condensation (a cold trap), as well as reduced residence time, to avoid further reaction of the oxygenates $[127,138]$. This approach can also be found in subsequent studies $[140,142,143]$. It can be concluded that a longer residence time may drive total combustion of $\mathrm{CH}_{4}$ to $\mathrm{CO}_{X}$ and $\mathrm{H}_{2} \mathrm{O}$, and there was an optimal residence time for the production of $\mathrm{CH}_{3} \mathrm{OH}$ or other oxygenates [139]. Additionally, the specified energy input (SEI) was compared to consider the effects of power density on the DOMTM process, in which a lower SEI value favors the selectivity toward methanol and suppresses the formation of carbon oxides [127], but an opposite experimental result can be found that the selectivity to oxygenated products (e.g., $\mathrm{CH}_{3} \mathrm{OH}$ and $\mathrm{HCHO}$ ) increased on high $\mathrm{SEI}$ value, mainly due to numbers of energetic electrons increased in $\mathrm{CH}_{4} / \mathrm{O}_{2}$ or $\mathrm{CH}_{4}$ / Air plasma [129,130,133].

Coupling of plasma with catalysts is capable of improving $\mathrm{CH}_{3} \mathrm{OH}$ selectivity. Indarto et al. found that $\mathrm{ZnO} / \mathrm{Al}_{2} \mathrm{O}_{3}$ catalyst in a DBD reactor doubled $\mathrm{CH}_{3} \mathrm{OH}$ selectivity to around $20 \%$, compared with plasma-only conditions [143]. A similar experiment was found on Ni-doped Y-stabilized $\mathrm{Zr}$ catalyst, with optimum $\mathrm{CH}_{3} \mathrm{OH}$ selectivity of 23\% [132]. Chawdhury et al. found that a $\mathrm{CH}_{4} / \mathrm{O}_{2}$ plasma packed with glass beads provided an optimal $\mathrm{CH}_{3} \mathrm{OH}$ selectivity of $35.4 \%$ [129]. Further work showed an improved $\mathrm{CH}_{3} \mathrm{OH}$ selectivity of $37 \%$ when using $\mathrm{CuO} / \gamma-\mathrm{Al}_{2} \mathrm{O}_{3}$ catalyst (5 wt.\% copper loading). Noticeably, a high $\mathrm{Cu}$ loading favored $\mathrm{HCHO}$ formation, with $20 \mathrm{wt} . \% \mathrm{Cu}$ loading yielding the highest $\mathrm{HCHO}$ selectivity of $34 \%$. Clearly, plasma packed with catalysts can produce significant amounts of oxygenates [130]. Compared with thermal reduction, a Pd/SBA-15 catalyst reduced by NTP showed much better catalytic performance (i.e., 70\% oxygenates selectivity and $\mathrm{CH}_{3} \mathrm{OH}$ selectivity of $32 \%$ ) [125]. The authors suggested the Pd-based catalysts reduced by NTP possess better surface characteristics, which can prevent the recombination and favor surface reactions, such as in-situ coupling, cleavage, $\mathrm{H}$-transfer and $\mathrm{CO} / \mathrm{CO}_{2}$ hydrogenation.

The position of the catalyst, embedded in the plasma discharge region, can largely influence the extent of various synergistic effects and thus the conversion rate. Ceramicsupported $\mathrm{Pt}, \mathrm{Fe}_{2} \mathrm{O}_{3}$ and $\mathrm{CeO}_{2}$ catalysts were located downstream of the discharge zone to promote $\mathrm{CH}_{4}$ /air plasma reaction, and the $\mathrm{Fe}_{2} \mathrm{O}_{3}$-based catalyst showed the best catalytic activity and the highest stability [128]. A decrease in the molar ratio of $\mathrm{CH}_{4}$ to air resulted in more $\mathrm{O}_{2}$ content available to react with the $\mathrm{CH}_{4}$ molecules, which led to a higher $\mathrm{CH}_{4}$ conversion. Packing of the catalysts had no significant effect on the $\mathrm{CH}_{4}$ conversion, but the $\mathrm{CH}_{3} \mathrm{OH}$ selectivity was enhanced for all three catalysts. Chen et al., compared in-plasma catalysis (IPC) and post-plasma catalysis (PPC) for $\mathrm{CH}_{4}$ partial oxidation to $\mathrm{CH}_{3} \mathrm{OH}$ [135]. The experimental results showed that IPC presented a better reaction performance, while PPC exhibited a higher stability because of lower carbon deposition. The reactive species 
(e.g., $\mathrm{O}_{3}, \mathrm{O}, \mathrm{CH}_{2}$ and $\mathrm{CH}_{3}$ ) were identified by in situ optical emission spectroscopy (OES) and FT-IR spectroscopy, and more active species were verified in IPC.

It is known that the synergy between catalytic process and plasma activation depends on both the nature of the packing material and the discharge characteristics. The high $\mathrm{CH}_{3} \mathrm{OH}$ selectivity ( 23\%) on Ni/YSZ catalyst can be attributed to the presence of more surface oxygen vacancies on the YSZ surface [132]. Chawdhury et al. compared the catalytic performance of glass beads, $\mathrm{Al}_{2} \mathrm{O}_{3}, \mathrm{TiO}_{2}$ and $\mathrm{CeO}_{2}$ catalysts [129]. In contrast to the expectations, glass beads exhibited better performance than the other catalysts, and the authors attributed this better performance to a more uniform distribution of micro discharges and improved field strength on the glass beads [129]. A porous structure of the catalyst surface is beneficial to the formation of micro discharge inside the pores, although modeling predicted that the latter should only occur for pore diameters larger than the so-called Debye length, which is typically several $100 \mathrm{~nm}$ [144-146]. Furthermore, plasma parameters, e.g., electron temperature and densities of radicals, ions and electrons, show significant enhancement with increasing dielectric constant of the packed material $[111,147]$ Therefore, it is reasonable to expect that catalysts with high dielectric constant, porous structure and highly efficient active sites may promote $\mathrm{CH}_{3} \mathrm{OH}$ formation in $\mathrm{CH}_{4} / \mathrm{O}_{2}$ plasma catalysis.

Recently, three supported transition metal catalysts $\left(\mathrm{Fe} / \gamma-\mathrm{Al}_{2} \mathrm{O}_{3}, \mathrm{Ni} / \gamma-\mathrm{Al}_{2} \mathrm{O}_{3}\right.$ and $\mathrm{Cu} / \gamma-\mathrm{Al}_{2} \mathrm{O}_{3}$ ) were compared in plasma-catalytic DOMTM, and the $\mathrm{Fe} / \gamma-\mathrm{Al}_{2} \mathrm{O}_{3}$ catalyst exhibited the highest $\mathrm{CH}_{3} \mathrm{OH}$ selectivity of $36 \%$, while the $\mathrm{Cu} / \gamma-\mathrm{Al}_{2} \mathrm{O}_{3}$ catalyst improved the selectivity of $C_{2}$ oxygenates to $9.4 \%$, mainly due to more acid sites on the surfaces of the $\mathrm{Cu}$ catalyst, as revealed by $\mathrm{NH}_{3}$-TPD experiments [118]. It is noticed that the plasmacatalytic DOMTM reaction involves both plasma gas-phase reactions and plasma-assisted surface reactions on the catalysts $[110,118]$. In the plasma gas phase, the reactions are initiated through a variety of inelastic collisions between the reactants $\left(\mathrm{CH}_{4}\right.$ and $\left.\mathrm{O}_{2}\right)$ and energetic electrons, generating a lot of reactive species (e. g., $\mathrm{CH}_{\mathrm{x}}$ and $\mathrm{O}$ ) and excited species, which are believed to play a crucial role for $\mathrm{CH}_{3} \mathrm{OH}$ production [118]. Combined with the results of optical emission spectroscopy (OES), the plausible reaction pathways in the plasma gas phase were proposed, as illustrated in Figure 21, and the $\mathrm{CH}_{3}$ radicals, mainly created by electron impact dissociation of $\mathrm{CH}_{4}$, were considered as the dominant and critical species in this reaction.

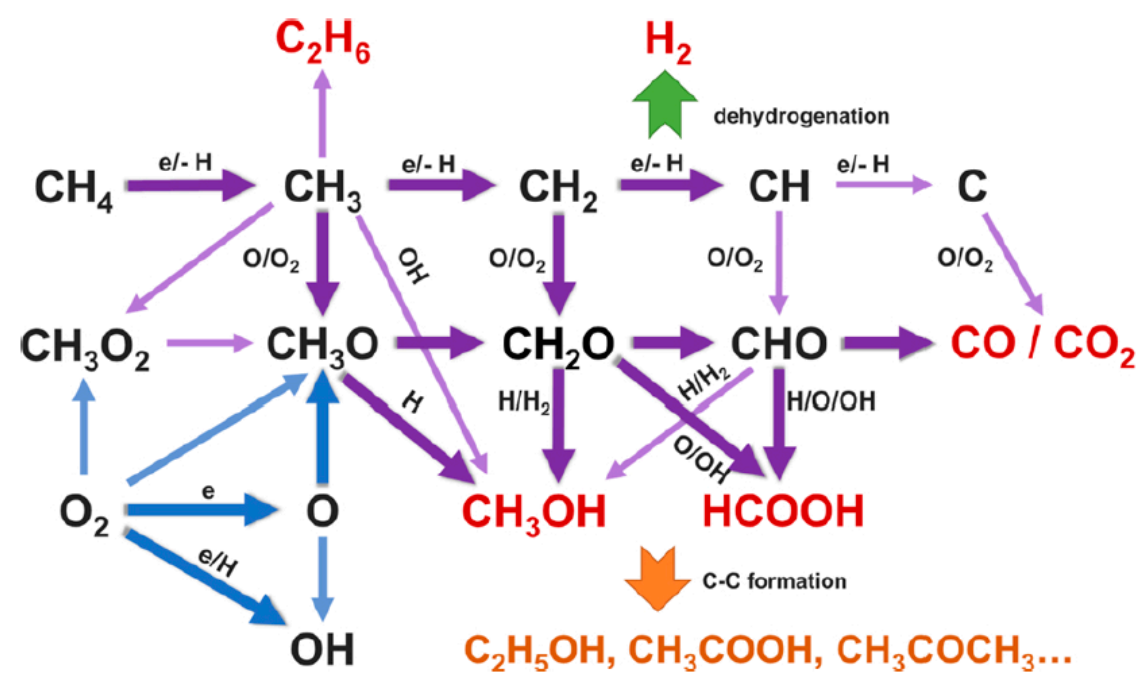

Figure 21. Proposed reaction pathways in the plasma-only reaction of $\mathrm{CH}_{4} / \mathrm{O}_{2}$ towards $\mathrm{CH}_{3} \mathrm{OH}$ and other oxygenates or hydrocarbons. (Red: Main products, Orange: $\mathrm{C}_{2+}$ oxygenates). Reproduced with permission from [118]. Copyright 2021 Elsevier.

The addition of an $\mathrm{Fe} / \gamma-\mathrm{Al}_{2} \mathrm{O}_{3}$ catalyst remarkably changed the OES intensities, and the main characteristic peaks $\left(\mathrm{CH}, \mathrm{H}, \mathrm{C}_{2}, \mathrm{CO}\right.$ and $\mathrm{O}$ peaks) of the $\mathrm{CH}_{4} / \mathrm{O}_{2}$ plasma were 
lowered by the catalyst packing [118]. The authors explained this by the adsorption of reactive species on the catalyst surface. Surface discharges are dominant in the plasmacatalytic reactions, while filamentary microdischarges were limited when packing catalysts in the discharge region $[116,148]$. For plasma-catalytic surface reactions, the reactions may take place via Langmuir-Hinshelwood (L-H) and Eley-Rideal (E-R) mechanisms, whereas in thermal catalytic reactions, the L-H mechanism dominates [110]. As shown in Figure 22, the radicals (e.g., $\mathrm{CH}_{x}, \mathrm{O}$ and $\mathrm{OH}$ ) can be formed in the plasma gas phase, and they can be directly adsorbed onto the catalyst surface. These chemisorption $\mathrm{CH}_{\mathrm{x}}$ species can be further oxidized to form $\mathrm{CH}_{\mathrm{x}} \mathrm{O}$ by $\mathrm{O}$ and $\mathrm{OH}$ radicals, via E- $\mathrm{R}$ and $\mathrm{L}$ $\mathrm{H}$ mechanisms, to speed up the $\mathrm{CH}_{3} \mathrm{OH}$ production by stepwise hydrogenation on the $\mathrm{Fe} / \gamma-\mathrm{Al}_{2} \mathrm{O}_{3}$ catalyst surface [118].
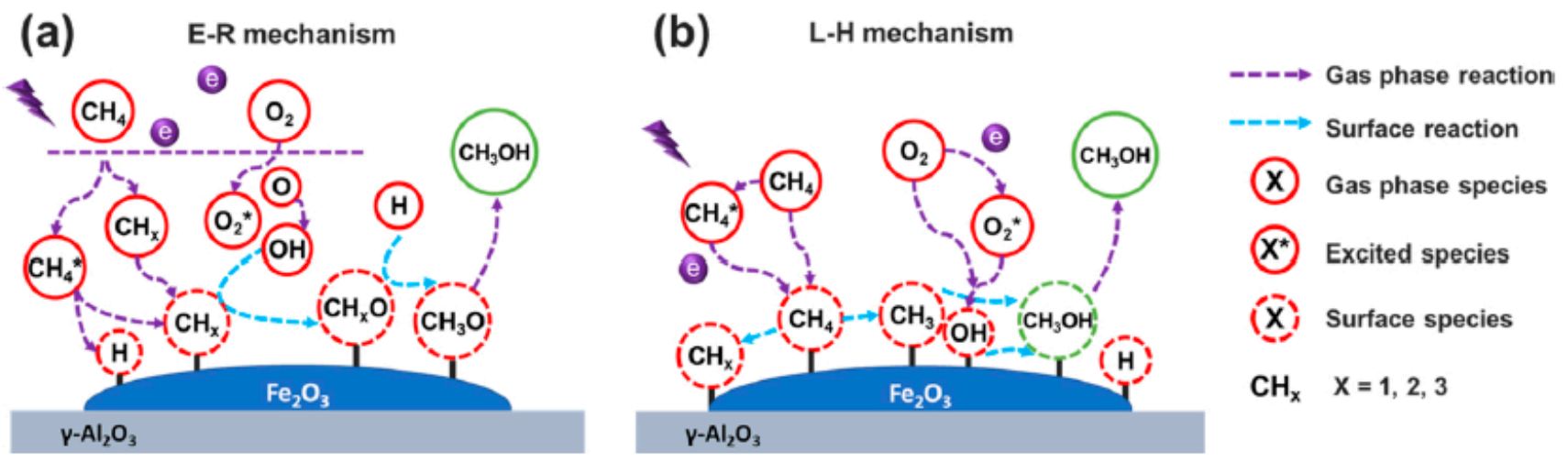

Figure 22. Proposed mechanisms in plasma-catalytic DOMTM on a $\mathrm{Fe} / \gamma-\mathrm{Al}_{2} \mathrm{O}_{3}$ surface [118]. Copyright 2021 Elsevier.

Kinetic modeling of $\mathrm{CH}_{4}$ conversion by plasma can help to determine the suitable parameters (such as feed gas ratio, residence time, and discharge power) for optimal performance $[149,150]$. De Bie et al., developed a one-dimensional fluid model to study the chemistry in a $\mathrm{CH}_{4} / \mathrm{O}_{2}$ and $\mathrm{CH}_{4} / \mathrm{CO}_{2}$ DBD plasma [149]. The dominant reaction pathways as predicted by the model for $\mathrm{CH}_{4}$ partial oxidation into $\mathrm{CH}_{3} \mathrm{OH}$ and other oxygenates are shown in Figure 23. Densities of the various plasma species as a function of residence time and gas mixing ratio were studied, and the simulation results showed that $\mathrm{CH}_{4} / \mathrm{CO}_{2}$ plasma favors the formation of $\mathrm{H}_{2}, \mathrm{CH}_{2} \mathrm{O}, \mathrm{CH}_{3} \mathrm{CHO}$, and $\mathrm{CH}_{2} \mathrm{CO}$, while the densities of $\mathrm{H}_{2} \mathrm{O}_{2}, \mathrm{CH}_{3} \mathrm{OH}, \mathrm{C}_{2} \mathrm{H}_{5} \mathrm{OH}, \mathrm{CH}_{3} \mathrm{OOH}$, and $\mathrm{C}_{2} \mathrm{H}_{5} \mathrm{OOH}$ were higher in $\mathrm{CH}_{4} / \mathrm{O}_{2}$ plasma. $\mathrm{CO}$ was formed at high density in both gas mixtures. Basically, the modelling results provide a better understanding of the reaction pathways, which is helpful for future experiments to acquire a maximum selectivity/yield with minimum energy consumption.

Next to the plasma chemistry, the reactions at the catalyst surface can also be studied by kinetic modeling. Loenders et al. investigated how different plasma species affect the partial oxidation of $\mathrm{CH}_{4}$ into $\mathrm{CH}_{3} \mathrm{OH}$ and other oxygenates on a $\mathrm{Pt}(111)$ surface [151]. In particular they focused on the effect of vibrationally excited $\mathrm{CH}_{4}$ and $\mathrm{O}_{2}$, as well as plasmagenerated radicals and stable intermediates on the reaction kinetics and mechanisms. The calculation results revealed that vibrational excitation enhances the turnover frequency (TOF) of catalytic $\mathrm{CH}_{4}$ dissociation and has good potential for improving the selectivities towards $\mathrm{CH}_{3} \mathrm{OH}, \mathrm{HCOOH}$, and $\mathrm{C}_{2}$ hydrocarbons, but the plasma-generated radicals mainly govern the surface chemistry. They enhance the TOFs of $\mathrm{CO}_{\mathrm{x}}$ and oxygenates, increase the selectivity towards oxygenates, and make the formation of $\mathrm{HCOOH}$ more significant on $\mathrm{Pt}(111)$, compared to thermal catalysis. Such modeling is of great interest for obtaining a better understanding of plasma-catalytic DOMTM [151]. 


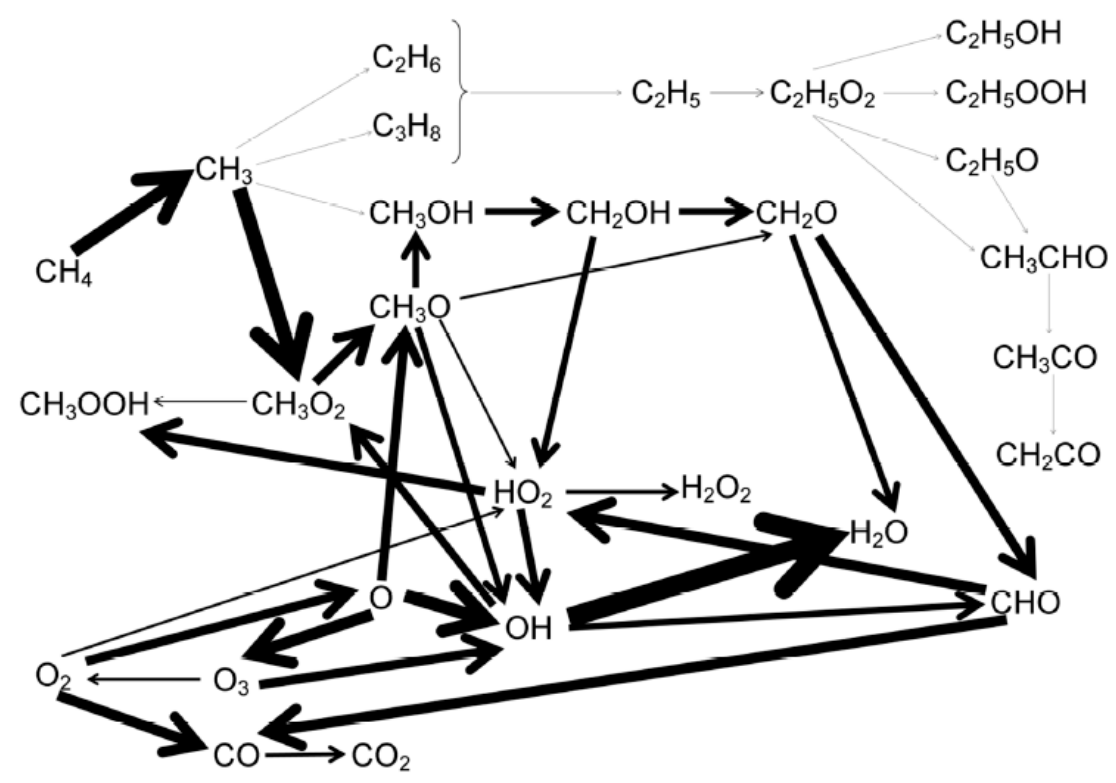

Figure 23. Schematic overview of the dominant reaction pathways for the conversion of $\mathrm{CH}_{4}$ and $\mathrm{O}_{2}$ into $\mathrm{CH}_{3} \mathrm{OH}$ and other oxygenates in a $70 / 30 \mathrm{CH}_{4} / \mathrm{O}_{2}$ gas mixture, as predicted by plasma chemical kinetics modeling. The thickness of the arrows is linearly proportional to the rate of the net reaction. Reproduced with permission from [149]. Copyright 2011 Wiley.

\subsection{Water as an Oxidant}

In a plasma reactor, energetic electrons are capable of dissociating $\mathrm{CH}_{4}$ together with $\mathrm{H}_{2} \mathrm{O}$ into reactive species (i.e., electrons, radicals, excited species and ions), which makes the direct reaction of $\mathrm{CH}_{4}$ and $\mathrm{H}_{2} \mathrm{O}$ to $\mathrm{CH}_{3} \mathrm{OH}$ possible under mild conditions. Tsuchiya et al. investigated a $\mathrm{CH}_{4} / \mathrm{H}_{2} \mathrm{O}$ plasma under different discharge conditions, such as gas flow rate, gas-mixing ratio, and discharge power, with total gas pressure of 1-10 Torr [152]. Several gaseous organic products, such as $\mathrm{C}_{2} \mathrm{H}_{6}, \mathrm{C}_{2} \mathrm{H}_{4}, \mathrm{C}_{2} \mathrm{H}_{2}$ and $\mathrm{CH}_{3} \mathrm{OH}$, were detected, and the $\mathrm{CH}_{3} \mathrm{OH}$ selectivity was sensitive to the ratio of $\mathrm{CH}_{4} / \mathrm{H}_{2} \mathrm{O}$. Under optimized conditions, the highest $\mathrm{CH}_{3} \mathrm{OH}$ selectivity reported was $20 \%$, and $\mathrm{CO}$ was detected to be the major product. The possible reaction pathways for DOMTM process in $\mathrm{CH}_{4} / \mathrm{H}_{2} \mathrm{O}$ plasma are illustrated in Figure 24.

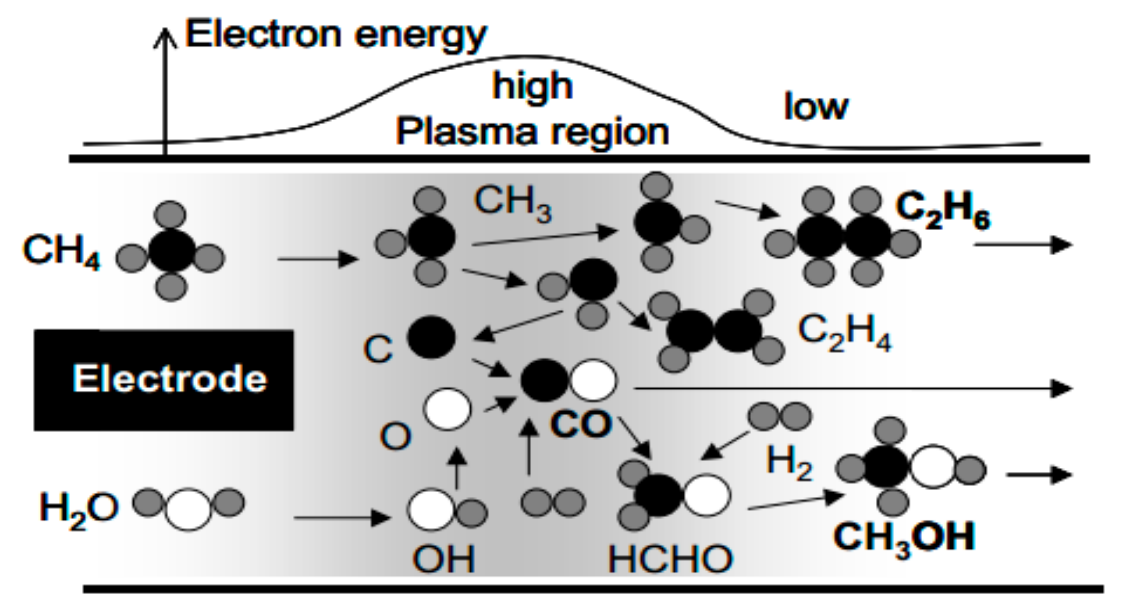

\section{Gas flow}

Figure 24. Major reaction pathways for the conversion of $\mathrm{CH}_{4}$ to $\mathrm{CH}_{3} \mathrm{OH}$ in $\mathrm{CH}_{4} / \mathrm{H}_{2} \mathrm{O}$ plasma. The upper part shows a schematic of the electron energy variation along the gas flow. Reproduced with permission from [152]. Copyright 2013 Springer. 
More insight in the mechanism in $\mathrm{CH}_{4} / \mathrm{H}_{2} \mathrm{O}$ plasma could be obtained from ${ }^{2} \mathrm{H}$, ${ }^{17} \mathrm{O}$ and ${ }^{18} \mathrm{O}$-labeled isotopologues experiment, and the results indicated that $\mathrm{O}$ atoms in the ${ }^{1} \mathrm{D}$ state inserted into $\mathrm{CH}_{4}$ could be considered as a possible mechanism for $\mathrm{CH}_{3} \mathrm{OH}$ production (i.e., $\left.\mathrm{CH}_{4}+\mathrm{O}\left({ }^{1} \mathrm{D}\right) \rightarrow \mathrm{CH}_{3} \mathrm{OH}\right)$ [153]. The second most abundant isotopologue of $\mathrm{CH}_{3} \mathrm{OH}$ was probably formed from a reaction $\left(\mathrm{CH}_{2} \mathrm{OH}+\mathrm{H}-\mathrm{CH}_{2} \mathrm{DOH}\right)$ with $\mathrm{CH}_{2} \mathrm{OH}$ radical. In addition, mMatrix isolation FTIR experiments revealed that $\mathrm{CH}_{4} / \mathrm{H}_{2} \mathrm{O} / \mathrm{Ar}$ plasma at $11 \mathrm{~K}$ yielded organic molecules, including $\mathrm{CH}_{3} \mathrm{OH}, \mathrm{CH}_{2} \mathrm{O}, \mathrm{CH}_{2} \mathrm{OH}, \mathrm{HOCH}$ and $\mathrm{HCO}$, with $\mathrm{CH}_{3} \mathrm{OH}$ as the major product.

\subsection{Discussion}

The previous sections gave an overview of results obtained by plasma-catalytic DOMTM based on different oxidants (i.e., $\mathrm{NO}_{\mathrm{x}}, \mathrm{O}_{2}$ and $\mathrm{H}_{2} \mathrm{O}$ ). It is clear that the synergistic effects in plasma catalysis are quite complicated. Evidently, the reaction kinetics, product yields and selectivities are influenced by alternative reaction pathways compared to classical heterogeneous catalysis, and there is clear need for a more fundamental understanding of the mutual interactions between plasma and catalyst. As mentioned in the introduction, the selective activation and controlled conversion of $\mathrm{CH}_{4}$ into $\mathrm{CH}_{3} \mathrm{OH}$ are considered the "holy grail" in catalysis, mainly due to the highly stable $\mathrm{C}-\mathrm{H}$ bond. This activation could be possibly realized by directing energy into $\mathrm{C}-\mathrm{H}$ bond vibrations, or by creating $\mathrm{CH}_{3}$ radicals, which is both possible in NTP at room temperature and atmosphere pressure $[109,151,154]$. These vibrationally or electronically excited species, or plasma radicals, may facilitate certain steps at the catalyst surface (e.g., dissociative adsorption), allowing other catalysts to perform better in the overall catalytic process, as compared to classical thermal catalysis [110,155]. Additionally, the lifetime of plasma-produced reactive species is a key parameter in determining their effectiveness in plasma catalysis. Figure 25 illustrates the various processes occurring in plasma catalysis, in the full range of time scale, from picoseconds to minutes [112]. The lifetime of reactive species in plasma catalysis is largely influenced by the operating conditions. Therefore, various parameters, such as reactor configuration, feed ratio, applied voltage, residence time, pressure and reactor wall temperature, should be fully considered and adjusted for the desired reaction.

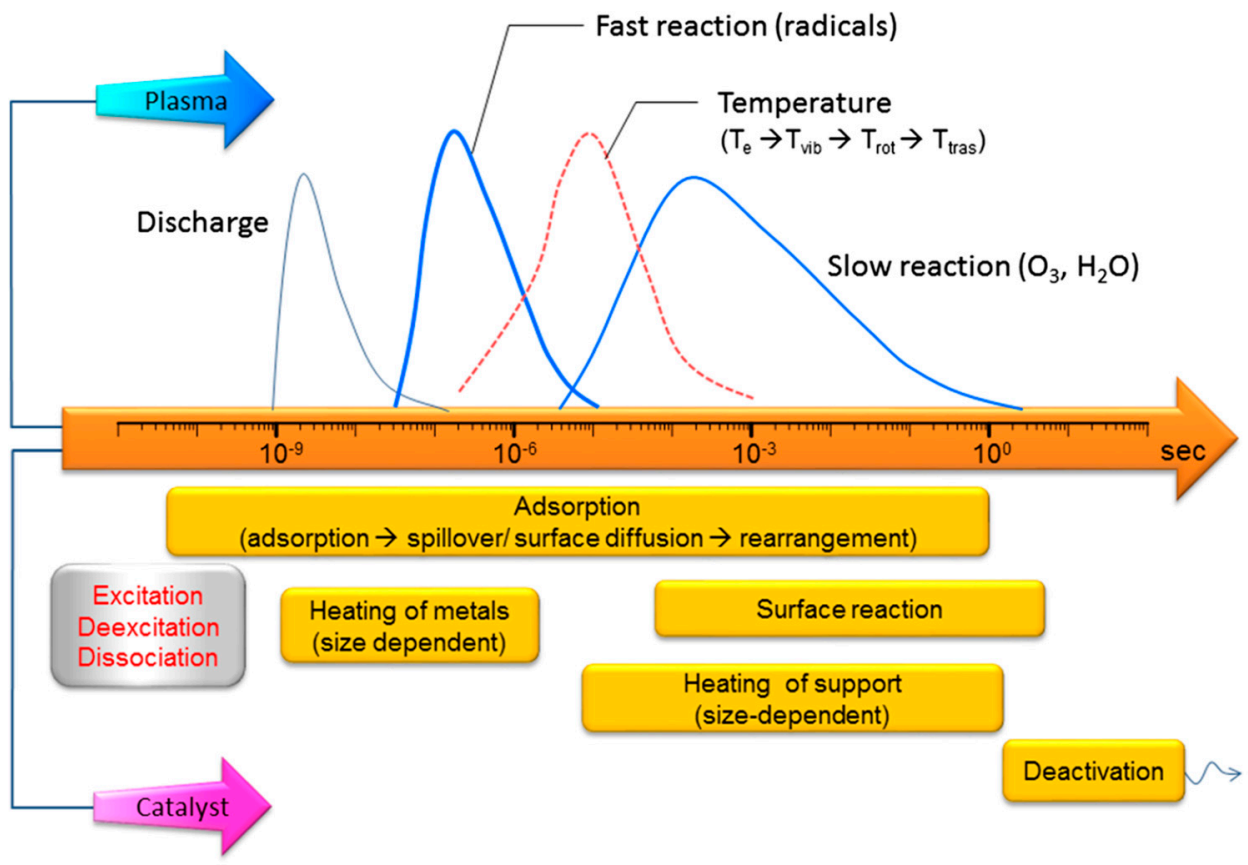

Figure 25. Characteristic time-scales in plasma catalysis. Reproduced with permission from [112]. Copyright, 2015 Springer. 
The activity of different catalysts inside the plasma region is determined by multiple factors ranging from chemical composition to physical properties. For DOMTM, another important factor is how to avoid deep oxidation of $\mathrm{CH}_{3} \mathrm{OH}$ to $\mathrm{CO}$ or $\mathrm{CO}_{2}$. Based on the mechanism of plasma catalysis, the adsorption probability is essential for all surfacemediated reaction mechanisms, namely the Langmuir-Hinshelwood (L-H), Eley-Rideal (E-R) and Mars-van Krevelen (MvK) mechanisms [110]. Recent work on plasma catalysis for $\mathrm{HCN}$ production by $\mathrm{CH}_{4} / \mathrm{NH}_{3} \mathrm{NTP}$ corroborated well with the barrierless Eley-Rideak (E-R) reactions between radicals generated in plasma and adsorbed species over the $\mathrm{Cu}$ surface, indicated by DFT calculation [156]. As for DOMTM, it is believed that E-R and L-H mechanism may occur in the case of plasma-catalysis on catalyst surfaces, whereas the L-H mechanism dominates in thermal catalytic reactions [118]. These findings mean that once $\mathrm{CH}_{3}$ radicals are formed, the subsequent reactions will be rapid. That is, the contribution of both E-R and L-H mechanism will be limited by the dissociation rate of $\mathrm{CH}_{4}$ through electron impact dissociation, implying that advanced plasma systems with fast dissociation rate of $\mathrm{CH}_{4}$ will promote $\mathrm{CH}_{4}$ conversion. On the other hand, pre-adsorption of reactive species is necessary for both E-R and L-H mechanisms to produce $\mathrm{CH}_{3} \mathrm{OH}$. This is important in further studies for rational design of catalysts, and the key is to seek advanced catalytic systems which could accelerate the hydrogenation of important intermediates, such as, $\mathrm{CH}_{3} \mathrm{O}$, as well as the desorption of $\mathrm{CH}_{3} \mathrm{OH}$ from the catalyst surface, improving $\mathrm{CH}_{3} \mathrm{OH}$ selectivity.

\section{Outlook and Conclusions}

This review paper provides a comprehensive overview about the recent progress in direct oxidation of methane to methanol (DOMTM) based on different oxidants, by both heterogeneous catalysis and plasma catalysis. Compared with the numerous studies in heterogeneous catalysis, much more research should be carried out in the field of plasma catalysis, to improve the $\mathrm{CH}_{4}$ conversion and target product selectivity. For this purpose, a better understanding of the underlying mechanisms is required, as they are much more complicated than in heterogeneous catalysis. This should be obtained by modeling, as well as by dedicated experiments. Fundamental studies on the interaction between plasma and catalysts are often limited by the lack of available instruments, especially for in situ measurements, which can provide the fundamental information about the behavior of the different species created in the gas-phase and on the catalytic surface.

As shown in Table 2, the reported selectivity of $\mathrm{CH}_{3} \mathrm{OH}$ remains low $(<40 \%)$ and further work needs to improve the plasma-catalytic performance. Innovations in new catalysts and concepts are needed to seek cost-effective, highly active and stable catalysts. A better catalyst selection strategy can be achieved only by combining advanced level simulation on plasma, catalysis and plasma-surface interactions and validate them with dedicated experiments. To achieve this goal, the advantage of plasma should be fully exploited, and at the same time, insights from heterogeneous catalysis (e.g., catalyst combination, reaction combination, active sites design, etc.) can help to further improve the potential of the promising field of plasma catalysis.

In summary, $\mathrm{CH}_{3} \mathrm{OH}$ is an important building block for the chemical industry, and DOMTM by several possible oxidants $\left(\mathrm{N}_{2} \mathrm{O}, \mathrm{H}_{2} \mathrm{O}_{2}, \mathrm{O}_{2}\right.$ and $\left.\mathrm{H}_{2} \mathrm{O}\right)$ could be interesting for this purpose. However, before DOMTM can be exploited commercially, the $\mathrm{CH}_{4}$ conversion and $\mathrm{CH}_{3} \mathrm{OH}$ yield in heterogeneous catalysis must be further improved, especially by a combination of various oxidants, which may effectively lower the energy barrier of $\mathrm{CH}_{4}$ oxidation, and avoid the over-oxidation of $\mathrm{CH}_{3} \mathrm{OH}$. For plasma-catalytic DOMTM, a much deeper fundamental understanding of the process is required by means of strong interdisciplinary studies. A combination of computer simulations with experiments will be needed for an in-depth understanding of the reaction mechanisms responsible for the synergy between plasma and catalysts. Therefore, future research should focus on a better understanding and rational screening of highly active catalysts. 
Author Contributions: Conceptualization: S.L., R.A., Y.Y. and A.B.; validation: S.L., R.A., Y.Y. and A.B.; formal analysis: S.L., R.A., Y.Y. and A.B.; resources: Y.Y. and A.B.; data curation: Y.Y. and A.B.; writing—original draft preparation: S.L., R.A.; writing—review and editing: Y.Y. and A.B.; supervision: Y.Y. and A.B.; funding acquisition: Y.Y. and A.B. All authors have read and agreed to the published version of the manuscript.

Funding: This research was funded by the Fundamental Research Funds for the Central Universities of China (DUT18JC42), the National Natural Science Foundation of China (21503032) PetroChina Innovation Foundation (2018D-5007-0501) and the TOP-BOF research project of the Research Council of the University of Antwerp (grant ID 32249). This research was supported by the China Scholarship Council (CSC). The authors warmly acknowledge CSC for their support.

Data Availability Statement: Data is contained within the article.

Conflicts of Interest: The authors declare no conflict of interest.

\section{References}

1. IEA. World Energy-Outlook 2019; Part A: World Global Energy Trend, Outlook for Natural Gas; IEA: Paris, France, 2019; pp. 176-187.

2. Schwach, P.; Pan, X.; Bao, X. Direct Conversion of Methane to Value-Added Chemicals over Heterogeneous Catalysts: Challenges and Prospects. Chem. Rev. 2017, 117, 8497-8520. [CrossRef]

3. Ravi, M.; Ranocchiari, M.; Van Bokhoven, J.A. The Direct Catalytic Oxidation of Methane to Methanol A Critical Assessment. Angew. Chem. Int. Ed. 2017, 56, 16464-16483. [CrossRef] [PubMed]

4. Han, B.; Yang, Y.; Xu, Y.; Etim, U.J.; Qiao, K.; Xu, B.; Yan, Z. A review of the direct oxidation of methane to methanol. Chin. J. Catal. 2016, 37, 1206-1215. [CrossRef]

5. Guo, Z.; Liu, B.; Zhang, Q.; Deng, W.; Wang, Y.; Yang, Y. Recent advances in heterogeneous selective oxidation catalysis for sustainable chemistry. Chem. Soc. Rev. 2014, 43, 3480-3524. [CrossRef] [PubMed]

6. Caballero, A.; Perez, P.J. Methane as a raw material in synthetic chemistry the final frontier. Chem. Soc. Rev. 2013, 42, 8809-8820. [CrossRef]

7. Zakaria, Z.; Kamarudin, S.K. Direct conversion technologies of methane to methanol: An overview. Renew. Sustain. Energy Rev. 2016, 65, 250-261. [CrossRef]

8. Raynes, S.; Shah, M.A.; Taylor, R.A. Direct conversion of methane to methanol with zeolites: Towards understanding the role of extra-framework d-block metal and zeolite framework type. Dalton Trans. 2019, 48, 10364-10384. [CrossRef]

9. Meng, X.; Cui, X.; Rajan, N.P.; Yu, L.; Deng, D.; Bao, X. Direct Methane Conversion under Mild Condition by Thermo-Electro or Photocatalysis. Chem 2019, 5, 2296-2325. [CrossRef]

10. Cui, X.; Li, H.; Wang, Y.; Hu, Y.; Hua, L.; Li, H.; Han, X.; Liu, Q.; Yang, F.; He, L.; et al. Room-Temperature Methane Conversion by Graphene-Confined Single Iron Atoms. Chem 2018, 4, 1902-1910. [CrossRef]

11. Periana, R.A.; Taube, D.J.; Evitt, E.R.; Loffler, D.G.; Wentrcek, P.R.; Voss, G.; Masuda, T. A Mercury Catalyzed High Yield System for the Oxidation of Methane to Methanol. Science 1993, 259, 340-343. [CrossRef] [PubMed]

12. Periana, R.A.; Tauba, D.J.; Gamble, S.; Taube, H.; Satoh, T.; Fujii, H. Platinum Catalysts for the High Yield Oxidation of Methane to a Methanol Derivative. Science 1998, 280, 560-564. [CrossRef] [PubMed]

13. Muehlhofer, M.; Strassner, T.; Herrmann, W.A. New Catalyst Systems for the Catalytic Conversion of Methane into Methanol. Angew. Chem. Int. Ed. 2002, 41, 1745-1747. [CrossRef]

14. Smith, M.R.; Ozkan, U.S. The Partial Oxidation of Methane to Formaldehyde: Role of different Crystal Planes of MoO 3 . J. Catal. 1993, 141, 124-139. [CrossRef]

15. Weng, T.; Wolf, E.E. Partial oxidation of methane on Mo/Sn/P silica supported catalysts. Appl. Catal. A Gen. 1993, 96, 383-396. [CrossRef]

16. Millner, T.; Neugebauer, J. Volatility of the oxides of tungsten and molybdenum in the presence of water vapour. Nature 1949, 163, 601-602. [CrossRef]

17. Barbero, J.A.; Alvarez, M.C.; Banares, M.A.; Pena, M.A.; Fierro, J.L.G. Breakthrough in the direct conversion of methane into C-1 Oxygenates. Chem. Commun. 2002, 11, 1184-1185. [CrossRef]

18. Chen, S.Y.; Willcox, D. Effect of vanadium oxide loading on the selective oxidation of methane over vanadium oxide $\left(\mathrm{V}_{2} \mathrm{O}_{5}\right) /$ silica. Ind. Eng. Chem. Res. 1993, 32, 584-587. [CrossRef]

19. Marturano, P.; Drozdová, L.; Kogelbauer, A.; Prins, R. Fe/ZSM-5 Prepared by Sublimation of $\mathrm{FeCl}_{3} \mathrm{The}^{\mathrm{Structure}}$ of the Fe Species as Determined by IR, 27Al MAS NMR, and EXAFS Spectroscopy. J. Catal. 2000, 192, 236-247. [CrossRef]

20. Battiston, A.A.; Bitter, J.H.; De-Groot, F.M.F.; Overweg, A.R.; Stephan, O.; Van Bokhoven, J.A.; Kooyman, P.J.; van-der-Spek, C.; Vanko, G.; Koningsberger, D.C. Evolution of Fe species during the synthesis of over-exchanged Fe/ZSM5 obtained by chemical vapor deposition of $\mathrm{FeCl}_{3}$. J. Catal. 2003, 213, 251-271. [CrossRef] 
21. Groothaert, M.H.; Van Bokhoven, J.A.; Battiston, A.A.; Weckhuysen, B.M.; Schoonheydt, R.A. Bis(mu-oxo)dicopper in Cu-ZSM-5 and its role in the decomposition of NO: A combined in situ XAFS, UV-Vis-Near-IR, and kinetic study. J. Am. Chem. Soc. 2003, 125, 7629-7640. [CrossRef]

22. Vanelderen, P.; Hadt, R.G.; Smeets, P.J.; Solomon, E.I.; Schoonheydt, R.A.; Sels, B.F. Cu-ZSM-5: A biomimetic inorganic model for methane oxidation. J. Catal. 2011, 284, 157-164. [CrossRef]

23. Agarwal, N.; Freakley, S.J.; McVicker, R.U.; Althahban, S.M.; Dimitratos, N.; He, Q.; Morgan, D.J.; Jenkins, R.L.; Willock, D.J.; Taylor, S.H.; et al. Aqueous Au-Pd colloids catalyze selective $\mathrm{CH}_{4}$ oxidation to $\mathrm{CH}_{3} \mathrm{OH}$ with $\mathrm{O}_{2}$ under mild conditions. Science 2017, 358, 223-227. [CrossRef] [PubMed]

24. Shan, J.; Li, M.; Allard, L.F.; Lee, S.; Flytzani-Stephanopoulos, M. Mild oxidation of methane to methanol or acetic acid on supported isolated rhodium catalysts. Nature 2017, 551, 605-608. [CrossRef] [PubMed]

25. Starokon, E.V.; Parfenov, M.V.; Arzumanov, S.S.; Pirutko, L.V.; Stepanov, A.G.; Panov, G.I. Oxidation of methane to methanol on the surface of FeZSM-5 zeolite. J. Catal. 2013, 300, 47-54. [CrossRef]

26. Bols, M.L.; Hallaert, S.D.; Snyder, B.E.R.; Devos, J.; Plessers, D.; Rhoda, H.M.; Dusselier, M.; Schoonheydt, R.A.; Pierloot, K.; Solomon, E.I.; et al. Spectroscopic Identification of the alpha-Fe/alpha-O Active Site in Fe-CHA Zeolite for the Low-Temperature Activation of the Methane C-H Bond. J. Am. Chem. Soc. 2018, 140, 12021-12032. [CrossRef] [PubMed]

27. Kim, Y.; Kim, T.Y.; Lee, H.; Yi, J. Distinct activation of Cu-MOR for direct oxidation of methane to methanol. Chem. Commun. 2017, 53, 4116-4119. [CrossRef] [PubMed]

28. Ab Rahim, M.H.; Forde, M.M.; Jenkins, R.L.; Hammond, C.; He, Q.; Dimitratos, N.; Lopez-Sanchez, J.A.; Carley, A.F.; Taylor, S.H.; Willock, D.J.; et al. Oxidation of Methane to Methanol with Hydrogen Peroxide Using Supported Gold-Palladium Alloy Nanoparticles. Angew. Chem. Int. Ed. 2013, 52, 1280-1284. [CrossRef] [PubMed]

29. Jin, Z.; Wang, L.; Zuidema, E.; Mondal, K.; Zhang, M.; Zhang, J.; Wang, C.; Meng, X.; Yang, H.; Mesters, C.; et al. Hydrophobic zeolite modification for in situ peroxide formation in methane oxidation to methanol. Science 2020, 367, 193-197. [CrossRef]

30. Kwon, Y.; Kim, T.Y.; Kwon, G.; Yi, J.; Lee, H. Selective Activation of Methane on Single-Atom Catalyst of Rhodium Dispersed on Zirconia for Direct Conversion. J. Am. Chem. Soc. 2017, 139, 17694-17699. [CrossRef] [PubMed]

31. Hammond, C.; Forde, M.M.; Ab Rahim, M.H.; Thetford, A.; He, Q.; Jenkins, R.L.; Dimitratos, N.; Lopez-Sanchez, J.A.; Dummer N.F.; Murphy, D.M.; et al. Direct catalytic conversion of methane to methanol in an aqueous medium by using copper-promoted Fe-ZSM-5. Angew. Chem. Int. Ed. 2012, 51, 5129-5133. [CrossRef]

32. Groothaert, M.H.; Smeets, P.J.; Sels, B.F.; Jacobs, P.A.; Schoonheydt, R.A. Selective Oxidation of Methane by the Bis( $\mu$-oxo)dicopper Core Stabilized on ZSM-5 and Mordenite Zeolites. J. Am. Chem. Soc. 2005, 127, 1394-1395. [CrossRef]

33. Pappas, D.K.; Martini, A.; Dyballa, M.; Kvande, K.; Teketel, S.; Lomachenko, K.A.; Baran, R.; Glatzel, P.; Arstad, B.; Berlier, G.; et al. The Nuclearity of the Active Site for Methane to Methanol Conversion in Cu-Mordenite: A Quantitative Assessment. J. Am. Chem. Soc. 2018, 140, 15270-15278. [CrossRef] [PubMed]

34. Pappas, D.K.; Borfecchia, E.; Dyballa, M.; Pankin, I.; Lomachenko, K.A.; Martini, A.; Signorile, M.; Teketel, S.; Arstad, B.; Berlier, G.; et al. Methane to Methanol: Structure-Activity Relationships for Cu-CHA. J. Am. Chem. Soc. 2017, 139, 14961-14975. [CrossRef]

35. Knorpp, A.J.; Pinar, A.B.; Newton, M.; Sushkevich, V.L.; Van Bokhoven, J.A. Copper-Exchanged Omega (MAZ) Zeolite: Copperconcentration Dependent Active Sites and its Unprecedented Methane to Methanol Conversion. ChemCatChem 2018, 10, 5593-5596. [CrossRef]

36. Beznis, N.V.; Weckhuysen, B.M.; Bitter, J.H. Partial Oxidation of Methane Over Co-ZSM-5: Tuning the Oxygenate Selectivity by Altering the Preparation Route. Catal. Lett. 2010, 136, 52-56. [CrossRef]

37. Shan, J.; Huang, W.; Nguyen, L.; Yu, Y.; Zhang, S.; Li, Y.; Frenkel, A.I.; Tao, F.F. Conversion of methane to methanol with a bent mono(mu-oxo)dinickel anchored on the internal surfaces of micropores. Langmuir 2014, 30, 8558-8569. [CrossRef] [PubMed]

38. Liu, Z.; Huang, E.; Orozco, I.; Liao, W.; Palomino, R.M.; Rui, N.; Duchon, T.; Nemsak, S.; Grinter, D.C.; Mahapatra, M.; et al. Water-promoted interfacial pathways in methane oxidation to methanol on a $\mathrm{CeO}_{2}-\mathrm{Cu}_{2} \mathrm{O}$ catalyst. Science 2020, 368, 513-517. [CrossRef] [PubMed]

39. Lustemberg, P.G.; Palomino, R.M.; Gutiérrez, R.A.; Grinter, D.C.; Vorokhta, M.; Liu, Z.; Ramírez, P.J.; Matolín, V.; GandugliaPirovano, M.V.; Senanayake, S.D.; et al. Direct Conversion of Methane to Methanol on Ni-Ceria Surfaces: Metal-Support Interactions and Water-Enabled Catalytic Conversion by Site Blocking. J. Am. Chem. Soc. 2018, 140, 7681-7687. [CrossRef] [PubMed]

40. Bai, S.; Yao, Q.; Xu, Y.; Cao, K.; Huang, X. Strong synergy in a lichen-like RuCu nanosheet boosts the direct methane oxidation to methanol. Nano Energy 2020, 71, 104566. [CrossRef]

41. Liu, R.S.; Iwamoto, M.; Lunsford, J.H. Partial Oxidation of Methane by Nitrous Oxide over Molybdenum Oxide supported on Silica. J. Chem. Soc. Chem. 1982, 1, 78-79. [CrossRef]

42. Rosenzweig, A.; Frederick, C.; Lippard, S.; Nordlund, P. Crystal structure of a bacterial non-haem iron hydroxylase that catalyses the biological oxidation of methane. Nature 1993, 366, 537-543. [CrossRef] [PubMed]

43. Panov, G.I.; Soboley, V.I.; Kharitonov, A.S. The role of iron in $\mathrm{N}_{2} \mathrm{O}$ decomposition on ZSM-5 zeolite and reactivity of the surface oxygen formed. J. Mol. Catal. 1990, 61, 85-97. [CrossRef]

44. Panov, G.I.; Sheveleva, G.A.; Kharitonov, A.S.; Romannikov, V.N.; Vostrikova, L.A. Oxidation of benzene to phenol by nitrous oxide over Fe-ZSM-5 zeolites. Appl. Catal. A Gen. 1992, 82, 31-36. [CrossRef] 
45. Panov, G.I.; Soboley, V.I.; Dubkov, K.A.; Parmon, V.N.; Ovanesyan, N.S.; Shilov, A.E.; Shteinman, A.A. Iron complexes in zeolites as a new model of methane monooxygenase. React. Kinet. Catal. Lett. 1997, 61, 251-258. [CrossRef]

46. Snyder, B.E.R.; Vanelderen, P.; Bols, M.L.; Hallaert, S.D.; Bottger, L.H.; Ungur, L.; Pierloot, K.; Schoonheydt, R.A.; Sels, B.F.; Solomon, E.I. The active site of low-temperature methane hydroxylation in iron-containing zeolites. Nature 2016, 536, 317-321. [CrossRef] [PubMed]

47. Michalkiewicz, B. Partial oxidation of methane to formaldehyde and methanol using molecular oxygen over Fe-ZSM-5. Appl. Catal. A Gen. 2004, 277, 147-153. [CrossRef]

48. Goltl, F.; Michel, C.; Andrikopoulos, P.C.; Love, A.M.; Hafner, J.; Hermans, I.; Sautet, P. Computationally Exploring Confinement Effects in the Methane-to-Methanol Conversion Over Iron Oxo Centers in Zeolites. ACS. Catal. 2016, 6, 8404-8409. [CrossRef]

49. Andrikopoulos, P.C.; Sobalik, Z.; Novakova, J.; Sazama, P.; Sklenak, S. Mechanism of framework oxygen exchange in Fe-zeolites: A combined DFT and mass spectrometry study. ChemPhysChem 2013, 14, 520-531. [CrossRef]

50. Mahyuddin, M.H.; Shiota, Y.; Yoshizawa, K. Methane selective oxidation to methanol by metal-exchanged zeolites: A review of active sites and their reactivity. Catal. Sci. Techol. 2019, 9, 1744-1768. [CrossRef]

51. Zhao, G.; Adesina, A.A.; Kennedy, E.M.; Stockenhuber, M. Formation of Surface Oxygen Species and the Conversion of Methane to Value-Added Products with $\mathrm{N}_{2} \mathrm{O}$ as Oxidant over Fe-Ferrierite Catalysts. ACS Catal. 2020, 10, 1406-1416. [CrossRef]

52. Park, K.S.; Kim, J.H.; Park, S.H.; Moon, D.J.; Roh, H.-S.; Chung, C.-H.; Um, S.H.; Choi, J.-H.; Bae, J.W. Direct activation of CH 4 to oxygenates and unsaturated hydrocarbons using $\mathrm{N}_{2} \mathrm{O}$ on Fe-modified zeolites. J. Mol. Catal. A Chem. 2017, 426, 130-140. [CrossRef]

53. Starokon, E.V.; Parfenov, M.V.; Pirutko, L.V.; Abornev, S.I.; Panov, G.I. Room Temperature Oxidation of Methane by R Oxygen and Extraction of Products from the FeZSM-5 Surface. J. Phys. Chem. 2011, 115, 2155-2161. [CrossRef]

54. Hammond, C.; Dimitratos, N.; Jenkins, R.; Lopez-Sanchez, T.; Kondrat, S.; Ab-Rahim, M.H.; Forde, M.; Thetford, A.; Taylor, S.H.; Hagen, H.; et al. Elucidation and Evolution of the Active Component within Cu/Fe/ZSM-5 for Catalytic Methane Oxidation: From Synthesis to Catalysis. ACS Catal. 2013, 3, 689-699. [CrossRef]

55. Mahyuddin, M.H.; Staykov, A.; Shiota, Y.; Yoshizawa, K. Direct Conversion of Methane to Methanol by Metal-Exchanged ZSM-5 Zeolite (Metal=Fe, Co, Ni, Cu). ACS Catal. 2016, 6, 8321-8331. [CrossRef]

56. Li, S.; Fan, L.; Song, L.; Cheng, D.; Chen, F. Influence of extra-framework Al in Fe-MOR catalysts for the direct conversion of methane to oxygenates by nitrous oxide. Chin. J. Chem. Eng. 2020. [CrossRef]

57. Parfenov, M.V.; Starokon, E.V.; Pirutko, L.V.; Panov, G.I. Quasicatalytic and catalytic oxidation of methane to methanol by nitrous oxide over FeZSM-5 zeolite. J. Catal. 2014, 318, 14-21. [CrossRef]

58. Liu, H.F.; Liu, R.S.; Liew, K.Y.; Johnson, R.E.; Lunsford, J.H. Partial Oxidation of Methane by Nitrous Oxide over molybdenum on silica. J. Am. Chem. Soc. 1984, 106, 4117-4121. [CrossRef]

59. Ipek, B.; Lobo, R.F. Catalytic conversion of methane to methanol on Cu-SSZ-13 using $\mathrm{N}_{2} \mathrm{O}$ as oxidant. Chem. Commun. 2016, 52, 13401-13404. [CrossRef] [PubMed]

60. Nematollahi, P.; Neyts, E.C. Direct oxidation of methane to methanol on Co embedded N-doped graphene: Comparing the role of $\mathrm{N}_{2} \mathrm{O}$ and $\mathrm{O}_{2}$ as oxidants. Appl. Catal. A Gen. 2020, 602, 117716. [CrossRef]

61. Montzka, S.A.; Dlugokencky, E.J.; Butler, J.H. Non- $\mathrm{CO}_{2}$ greenhouse gases and climate change. Nature 2011, 476, 43-50. [CrossRef] [PubMed]

62. Goor, G.; Glenneberg, J.; Jacobi, S.; Dadabhoy, J.; Candido, E. Hydrogen Peroxide. Ullmann's Encycl. Ind. Chem. 2019. [CrossRef]

63. Guo, X.; Fang, G.; Li, G.; Ma, H.; Fan, H.; Yu, L.; Ma, C.; Wu, X.; Deng, D.; Wei, M.; et al. Direct nonoxidative conversion of methane to ethylene, aromatics, and hydrogen. Science 2014, 344, 616-619. [CrossRef]

64. Song, S.; Wang, X.; Zhang, $\mathrm{H}$. $\mathrm{CeO}_{2}$-encapsulated noble metal nanocatalysts: Enhanced activity and stability for catalytic application. NPG Asia Mater. 2015, 7, e179. [CrossRef]

65. Huang, W.; Zhang, S.; Tang, Y.; Li, Y.; Nguyen, L.; Li, Y.; Shan, J.; Xiao, D.; Gagne, R.; Frenkel, A.I.; et al. Low-Temperature Transformation of Methane to Methanol on $\mathrm{Pd}_{1} \mathrm{O}_{4}$ Single Sites Anchored on the Internal Surface of Microporous Silicate. Angew. Chem. Int. Ed. 2016, 55, 13441-13445. [CrossRef] [PubMed]

66. Tang, Y.; Li, Y.; Fung, V.; Jiang, D.E.; Huang, W.; Zhang, S.; Iwasawa, Y.; Sakata, T.; Nguyen, L.; Zhang, X.; et al. Single rhodium atoms anchored in micropores for efficient transformation of methane under mild conditions. Nat. Commun. 2018, 9, 1231. [CrossRef]

67. Edwards, J.K.; Solsona, B.E.; Landon, P.; Carley, A.F.; Herzing, A.; Kiely, C.J.; Hutchings, G.J. Direct synthesis of hydrogen peroxide from $\mathrm{H}_{2}$ and $\mathrm{O}_{2}$ using $\mathrm{TiO}_{2}$-supported $\mathrm{Au}-\mathrm{Pd}$ catalysts. J. Catal. 2005, 236, 69-79. [CrossRef]

68. Kesavan, L.; Tiruvalam, R.; Ab Rahim, M.H.; Bin Saiman, M.I.; Enache, D.I.; Jenkins, R.L.; Dimitratos, N.; Lopez-Sanchez, J.A.; Taylor, S.H.; Knight, D.W.; et al. Solvent-free oxidation of primary carbon-hydrogen bonds in toluene using Au-Pd alloy nanoparticles. Science 2011, 331, 195-199. [CrossRef] [PubMed]

69. Pritchard, J.; Piccinini, M.; Tiruvalam, R.; He, Q.; Dimitratos, N.; Lopez-Sanchez, J.A.; Morgan, D.J.; Carley, A.F.; Edwards, J.K.; Kiely, C.J.; et al. Effect of heat treatment on Au-Pd catalysts synthesized by sol immobilisation for the direct synthesis of hydrogen peroxide and benzyl alcohol oxidation. Catal. Sci. Technol. 2013, 3, 308-317. [CrossRef]

70. Thetford, A.; Hutchings, G.J.; Taylor, S.H.; Willock, D.J. The decomposition of $\mathrm{H}_{2} \mathrm{O}_{2}$ over the components of Au/TiO 2 catalysts. Proc. Math. Phys. Eng. Sci. 2011, 467, 1885-1899. 
71. Ab-Rahim, M.H.; Armstrong, R.D.; Hammond, C.; Dimitratos, N.; Freakley, S.J.; Forde, M.M.; Morgan, D.J.; Lalev, G.; Jenkins, R.L.; Lopez-Sanchez, J.A.; et al. Low temperature selective oxidation of methane to methanol using titania supported gold palladium copper catalysts. Catal. Sci. Technol. 2016, 6, 3410-3418. [CrossRef]

72. Serra-Maia, R.; Michel, F.M.; Kang, Y.; Stach, E.A. Decomposition of Hydrogen Peroxide Catalyzed by AuPd Nanocatalysts during Methane Oxidation to Methanol. ACS Catal. 2020, 10, 5115-5123. [CrossRef]

73. Xie, J.; Jin, R.; Li, A.; Bi, Y.; Ruan, Q.; Deng, Y.; Zhang, Y.; Yao, S.; Sankar, G.; Ma, D.; et al. Highly selective oxidation of methane to methanol at ambient conditions by titanium dioxide-supported iron species. Nat. Catal. 2018, 1, 889-896. [CrossRef]

74. Xu, J.; Armstrong, R.D.; Shaw, G.; Dummer, N.F.; Freakley, S.J.; Taylor, S.H.; Hutchings, G.J. Continuous selective oxidation of methane to methanol over Cu- and Fe-modified ZSM-5 catalysts in a flow reactor. Catal. Today 2016, 270, 93-100. [CrossRef]

75. Kim, M.S.; Park, K.H.; Cho, S.J.; Park, E.D. Partial oxidation of methane with hydrogen peroxide over Fe-ZSM-5 catalyst. Catal. Today 2020. [CrossRef]

76. Kalamaras, C.; Palomas, D.; Bos, R.; Horton, A.; Crimmin, M.; Hellgardt, K. Selective Oxidation of Methane to Methanol Over Cuand Fe-Exchanged Zeolites: The Effect of Si/Al Molar Ratio. Catal. Lett. 2016, 146, 483-492. [CrossRef]

77. Shahami, M.; Shantz, D.F. Zeolite acidity strongly influences hydrogen peroxide activation and oxygenate selectivity in the partial oxidation of methane over M,Fe-MFI (M: Ga, Al, B) zeolites. Catal. Sci. Technol. 2019, 9, 2945-2951. [CrossRef]

78. Forde, M.M.; Armstrong, R.D.; Hammond, C.; He, Q.; Jenkins, R.L.; Kondrat, S.A.; Dimitratos, N.; Lopez-Sanchez, J.A.; Taylor, S.H.; Willock, D.; et al. Partial oxidation of ethane to oxygenates using Fe- and Cu-containing ZSM-5. J. Am. Chem. Soc. 2013, 135, 11087-11099. [CrossRef] [PubMed]

79. Tomkins, P.; Ranocchiari, M.; Van Bokhoven, J.A. Direct Conversion of Methane to Methanol under Mild Conditions over Cu-Zeolites and beyond. Acc. Chem. Res. 2017, 50, 418-425. [CrossRef] [PubMed]

80. Markovits, M.A.C.; Jentys, A.; Tromp, M.; Sanchez-Sanchez, M.; Lercher, J.A. Effect of Location and Distribution of Al Sites in ZSM-5 on the Formation of Cu-Oxo Clusters Active for Direct Conversion of Methane to Methanol. Top. Catal. 2016, 59, 1554-1563. [CrossRef]

81. Smeets, P.J.; Groothaert, M.H.; Schoonheydt, R.A. Cu based zeolites: A UV-vis study of the active site in the selective methane oxidation at low temperatures. Catal. Today 2005, 110, 303-309. [CrossRef]

82. Woertink, J.S.; Smeets, P.J.; Groothaert, M.H.; Vance, M.A.; Sels, B.F.; Schoonheydt, R.A.; Solomon, E.I. A [Cu $\left.{ }_{2} \mathrm{O}\right]^{2+}$ core in $^{2}$ Cu-ZSM-5, the active site in the oxidation of methane to methanol. Proc. Natl. Acad. Sci. USA 2009, 106, 18908-18913. [CrossRef]

83. Smeets, P.J.; Hadt, R.G.; Woertink, J.S.; Vanelderen, P.; Schoonheydt, R.A.; Sels, B.F.; Solomon, E.I. Oxygen Precursor to the Reactive Intermediate in Methanol Synthesis by Cu-ZSM-5. J. Am. Chem. Soc. 2010, 132, 14736-14738. [CrossRef]

84. Groothaert, M.H.; Lievens, K.; Leeman, H.; Weckhuysen, B.M.; Schoonheydt, R.A. An operando optical fiber UV-vis spectroscopic study of the catalytic decomposition of $\mathrm{NO}$ and $\mathrm{N}_{2} \mathrm{O}$ over Cu-ZSM-5. J. Catal. 2003, 220, 500-512. [CrossRef]

85. Grundner, S.; Markovits, M.A.C.; Li, G.; Tromp, M.; Pidko, E.A.; Hensen, E.J.M.; Jentys, A.; Sanchez-Sanchez, M.; Lercher, J.A. Single-site trinuclear copper oxygen clusters in mordenite for selective conversion of methane to methanol. Nat. Commun. 2015, 6, 7546. [CrossRef] [PubMed]

86. Sushkevich, V.L.; Palagin, D.; Van Bokhoven, J.A. The Effect of the Active-Site Structure on the Activity of Copper Mordenite in the Aerobic and Anaerobic Conversion of Methane into Methanol. Angew. Chem. Int. Ed. 2018, 57, 8906-8910. [CrossRef] [PubMed]

87. Park, M.B.; Ahn, S.H.; Ranocchiari, M.; Van Bokhoven, J.A. Comparative Study of Diverse Cu-Zeolites for Conversion of Methane-to-Methanol. ChemCatChem 2017, 9, 3705-3713. [CrossRef]

88. Mahyuddin, M.H.; Tanaka, T.; Shiota, Y.; Staykov, A.; Yoshizawa, K. Methane Partial Oxidation over $\left[\mathrm{Cu}{ }_{2}(\mu-\mathrm{O})\right]^{2+}$ and $\left[\mathrm{Cu}_{3}(\mu-\mathrm{O})^{3}\right]^{2+}$ Active Species in Large-Pore Zeolites. ACS Catal. 2018, 8, 1500-1509. [CrossRef]

89. Vanelderen, P.; Snyder, B.E.R.; Tsai, M.L.; Hadt, R.G.; Vancauwenbergh, J.; Coussens, O.; Schoonheydt, R.A.; Sels, B.F.; Solomon, E.I. Spectroscopic definition of the copper active sites in mordenite: Selective methane oxidation. J. Am. Chem. Soc. 2015, 137, 6383-6392. [CrossRef]

90. Wulfers, M.J.; Teketel, S.; Ipek, B.; Lobo, R.F. Conversion of methane to methanol on copper-containing small-pore zeolites and zeotypes. Chem. Commun. 2015, 51, 4447-4450. [CrossRef] [PubMed]

91. Sheppard, T.; Hamill, C.D.; Goguet, A.; Rooney, D.W.; Thompson, J.M. A low temperature, isothermal gas-phase system for conversion of methane to methanol over Cu-ZSM-5. Chem. Commun. 2014, 50, 11053-11055. [CrossRef]

92. Tomkins, P.; Mansouri, A.; Bozbag, S.E.; Krumeich, F.; Park, M.B.; Alayon, E.M.C.; Ranocchiari, M.; Van Bokhoven, J.A. Isothermal Cyclic Conversion of Methane into Methanol over Copper-Exchanged Zeolite at Low Temperature. Angew. Chem. Int. Ed. 2016, 55, 5467-5471. [CrossRef]

93. Sushkevich, V.L.; Van Bokhoven, J.A. Methane-to-Methanol: Activity Descriptors in Copper-Exchanged Zeolites for the Rational Design of Materials. ACS Catal. 2019, 9, 6293-6304. [CrossRef]

94. Krisnandi, Y.K.; Putra, B.A.P.; Bahtiar, M.; Zahara; Abdullah, I.; Howe, R.F. Partial Oxidation of Methane to Methanol over Heterogeneous Catalyst Co/ZSM-5. Procedia Chem. 2015, 14, 508-515. [CrossRef]

95. Meesub, C.; Tannititam, P.; Kruemek, P.; Triamnak, N.; Chotigkrai, N. Direct stepwise oxidation of methane to methanol via zinc promoted copper containing mordenite. In Proceedings of the 8th International Thai Institute of Chemical Engineering and Applied Chemistry Conference, Pattaya, Thailand, 8-9 November 2018; pp. 45-50. 
96. Zuo, Z.; Ramirez, P.J.; Senanayake, S.; Liu, P.; Rodriguez, J.A. Low-Temperature Conversion of Methane to Methanol on $\mathrm{CeOx} / \mathrm{Cu}_{2} \mathrm{O}$ Catalysts: Water Controlled Activation of the C-H Bond. J. Am. Chem. Soc. 2016, 138, 13810-13813. [CrossRef]

97. Lange, J.P.; Sushkevich, V.L.; Knorpp, M.J.; Van Bokhoven, J.A. Methane to Methanol via Chemical Looping Economic Potential and Guidance for Future Research. Ind. Eng. Chem. Res. 2019, 58, 8674-8680. [CrossRef]

98. Sushkevich, V.L.; Palagin, D.; Ranocchiari, M.; Van Bokhoven, J.A. Selective anaerobic oxidation of methane enables direct synthesis of methanol. Science 2017, 356, 523-527. [CrossRef] [PubMed]

99. Palagin, D.; Sushkevich, V.L.; van Bokhoven, J.A. Water Molecules Facilitate Hydrogen Release in Anaerobic Oxidation of Methane to Methanol over Cu/Mordenite. ACS Catal. 2019, 9, 10365-10374. [CrossRef]

100. Jeong, Y.R.; Jung, H.; Kang, J.; Han, J.W.; Park, E.D. Continuous Synthesis of Methanol from Methane and Steam over CopperMordenite. ACS Catal. 2021, 11, 1065-1070. [CrossRef]

101. Koishybay, A.; Shantz, D.F. Water Is the Oxygen Source for Methanol Produced in Partial Oxidation of Methane in a Flow Reactor over Cu-SSZ-13. J. Am. Chem. Soc. 2020, 142, 11962-11966. [CrossRef] [PubMed]

102. Periana, R.A. Comment on "Selective anaerobic oxidation of methane enables direct synthesis of methanol". Science 2017, 358, eaan5970. [CrossRef]

103. Sushkevich, V.L.; Palagin, D.; Ranocchiari, M.; Van Bokhoven, J.A. Response to Comment on "Selective anaerobic oxidation ofmethane enables direct synthesis ofmethanol". Science 2017, 358, eaan6083. [CrossRef] [PubMed]

104. Labinger, J.A. Comment on "Selective anaerobic oxidation of methane enables direct synthesis of methanol". Science 2018, 359, eaar4968. [CrossRef] [PubMed]

105. Dinh, K.T.; Sullivan, M.M.; Narsimhan, K.; Serna, P.; Meyer, R.J.; Dinca, M.; Roman-Leshkov, Y. Continuous Partial Oxidation of Methane to Methanol Catalyzed by Diffusion-Paired Copper Dimers in Copper-Exchanged Zeolites. J. Am. Chem. Soc. 2019, 141, 11641-11650. [CrossRef] [PubMed]

106. Le, H.V.; Parishan, S.; Sagaltchik, A.; Ahi, H.; Trunschke, A.; Schomacker, R.; Thomas, A. Stepwise Methane-to-Methanol Conversion on CuO/SBA-15. Chemistry 2018, 24, 12592-12599. [CrossRef] [PubMed]

107. Yumura, T.; Hirose, Y.; Wakasugi, T.; Kuroda, Y.; Kobayashi, H. Roles of Water Molecules in Modulating the Reactivity of Dioxygen-Bound Cu-ZSM-5 toward Methane: A Theoretical Prediction. ACS Catal. 2016, 6, 2487-2495. [CrossRef]

108. Snoeckx, R.; Bogaerts, A. Plasma technology-A novel solution for $\mathrm{CO}_{2}$ conversion? Chem. Soc. Rev. 2017, 46, 5805-5863. [CrossRef] [PubMed]

109. Whitehead, J.C. Plasma catalysis the known knowns, the known unknowns and the unknown unknowns. J. Phys. D Appl. Phys. 2016, 49, 243001. [CrossRef]

110. Bogaerts, A.; Tu, X.; Whitehead, J.C.; Centi, G.; Lefferts, L.; Guaitella, O.; Azzolina-Jury, F.; Kim, H.-H.; Murphy, A.B.; Schneider, W.F.; et al. The 2020 plasma catalysis roadmap. J. Phys. D Appl. Phys. 2020, 53, 443001. [CrossRef]

111. Neyts, E.C.; Ostrikov, K.K.; Sunkara, M.K.; Bogaerts, A. Plasma Catalysis: Synergistic Effects at the Nanoscale. Chem. Rev. 2015, 115, 13408-13446. [CrossRef]

112. Kim, H.H.; Teramoto, Y.; Ogata, A.; Takagi, H.; Nanba, T. Plasma Catalysis for Environmental Treatment and Energy Applications. Plasma Chem. Plasma Process. 2015, 36, 45-72. [CrossRef]

113. Liu, M.; Yi, Y.; Wang, L.; Guo, H.; Bogaerts, A. Hydrogenation of Carbon Dioxide to Value-Added Chemicals by Heterogeneous Catalysis and Plasma Catalysis. Catalysts 2019, 9, 275. [CrossRef]

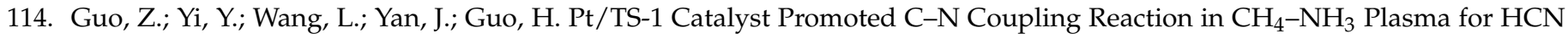
Synthesis at Low Temperature. ACS Catal. 2018, 8, 10219-10224. [CrossRef]

115. Wang, L.; Yi, Y.; Wu, C.; Guo, H.; Tu, X. One-Step Reforming of $\mathrm{CO}_{2}$ and $\mathrm{CH}_{4}$ into High-Value Liquid Chemicals and Fuels at Room Temperature by Plasma-Driven Catalysis. Angew. Chem. Int. Ed. 2017, 56, 13679-13683. [CrossRef]

116. Tu, X.; Whitehead, J.C. Plasma-catalytic dry reforming of methane in an atmospheric dielectric barrier discharge: Understanding the synergistic effect at low temperature. Appl. Catal. B Environ. 2012, 125, 439-448. [CrossRef]

117. Wang, L.; Yi, Y.; Guo, H.; Tu, X. Atmospheric Pressure and Room Temperature Synthesis of Methanol through Plasma-Catalytic Hydrogenation of $\mathrm{CO}_{2}$. ACS Catal. 2017, 8, 90-100. [CrossRef]

118. Chawdhury, P.; Wang, Y.; Ray, D.; Mathieu, S.; Wang, N.; Harding, J.; Bin, F.; Tu, X.; Subrahmanyam, C. A promising plasmacatalytic approach towards single-step methane conversion to oxygenates at room temperature. Appl. Catal. B Environ. 2021, 284, 119735. [CrossRef]

119. Puliyalil, H.; Jurkovic, D.L.; Dasireddy, V.D.B.C.; Likozar, B. A review of plasma-assisted catalytic conversion of gaseous carbon dioxide and methane into value-added platform chemicals and fuels. RSC Adv. 2018, 8, 27481-27508. [CrossRef]

120. Liu, S.; Winter, L.R.; Chen, J.G. Review of plasma-assisted catalysis for selective generation of oxygenates from $\mathrm{CO}_{2}$ and $\mathrm{CH}_{4}$. ACS Catal. 2020, 10, 2855-2871. [CrossRef]

121. Matsumoto, H.; Tanabe, S.; Okitsu, K.; Hayashi, Y.; Suib, S.L. Selective Oxidation of Methane to Methanol and Formaldehyde with Nitrous Oxide in a Dielectric-Barrier Discharge-Plasma Reactor. J. Phys. Chem. A 2001, 105, 5304-5308. [CrossRef]

122. Mahammadunnisa, S.; Krushnamurty, K.; Subrahmanyam, C. Catalytic nonthermal plasma assisted co-processing of methane and nitrous oxide for methanol production. Catal. Today 2015, 256, 102-107. [CrossRef]

123. Mahammadunnisa, S.; Reddy, P.M.K.; Subrahmanyam, C. Nonthermal plasma assisted co-processing of $\mathrm{CH}_{4}$ and $\mathrm{N}_{2} \mathrm{O}$ for methanol production. RSC Adv. 2014, 4, 4034-4036. [CrossRef] 
124. Yao, S.L.; Takemoto, T.; Ouyang, F.; Nakayama, A.; Suzuki, E.; Mizuno, A.; Okumoto, M. Selective Oxidation of Methane Using a Non-Thermal Pulsed Plasma. Energy Fuels 2000, 14, 459-463. [CrossRef]

125. Chawdhury, P.; Bhargavi, K.V.S.S.; Subrahmanyam, C. Enhanced synergy by plasma reduced Pd nanoparticles on in-plasma catalytic methane conversion to liquid oxygenates. Catal. Commun. 2020,147, 106139. [CrossRef]

126. Larkin, D.W.; Lobban, L.L.; Mallinson, R.G. The direct partial oxidation of methane to organic oxygenates using a dielectric barrier discharge reactor as a catalytic reactor analog. Catal. Today 2001, 71, 199-210. [CrossRef]

127. Zhou, L.M.; Xue, B.; Kogelschatz, U.; Eliasson, B. Partial Oxidation of Methane to Methanol with Oxygen or Air in a Nonequilibrium Discharge Plasma. Plasma Chem. Plasma Process. 1998, 18, 375-393. [CrossRef]

128. Chen, L.; Zhang, X.-W.; Huang, L.; Lei, L.-C. Partial oxidation of methane with air for methanol production in a post-plasma catalytic system. Chem. Eng. Process. 2009, 48, 1333-1340. [CrossRef]

129. Chawdhury, P.; Ray, D.; Subrahmanyam, C. Single step conversion of methane to methanol assisted by nonthermal plasma. Fuel Process. Technol. 2018, 179, 32-41. [CrossRef]

130. Chawdhury, P.; Ray, D.; Vinodkumar, T.; Subrahmanyam, C. Catalytic DBD plasma approach for methane partial oxidation to methanol under ambient conditions. Catal. Today 2019, 337, 117-125. [CrossRef]

131. Indarto, A. Methanol synthesis from methane and oxygen with $[\mathrm{Ga} \mathrm{Cr}] / \mathrm{Cu}-\mathrm{Zn}-\mathrm{Al}$ catalyst in a dielectric barrier discharge. Ionics 2014, 20, 445-449. [CrossRef]

132. Indarto, A.; Lee, H.; Choi, J.W.; Song, H.K. Partial Oxidation of Methane with Yttria-stabilized Zirconia Catalyst in a Dielectric Barrier Discharge. Energy Sources Part A 2008, 30, 1628-1636. [CrossRef]

133. Chawdhury, P.; Kumar, D.; Subrahmanyam, C. NTP reactor for a single stage methane conversion to methanol: Influence of catalyst addition and effect of promoters. Chem. Eng. J. 2019, 372, 638-647. [CrossRef]

134. Chen, L.; Zhang, X.; Huang, L.; Lei, L. Post-Plasma Catalysis for Methane Partial Oxidation to Methanol: Role of the CopperPromoted Iron Oxide Catalyst. Chem. Eng. Technol. 2010, 33, 2073-2081. [CrossRef]

135. Chen, L.; Zhang, X.; Huang, L.; Lei, L. Application of in-plasma catalysis and post-plasma catalysis for methane partial oxidation to methanol over a $\mathrm{Fe}_{2} \mathrm{O}_{3}-\mathrm{CuO} / \gamma-\mathrm{Al}_{2} \mathrm{O}_{3}$ catalyst. J. Nat. Gas Chem. 2010, 19, 628-637. [CrossRef]

136. Indarto, A. Partial oxidation of methane to methanol with nitrogen dioxide in dielectric barrier discharge plasma: Experimental and molecular modeling. Plasma Sources Sci. Technol. 2016, 25, 025002. [CrossRef]

137. Aghamir, F.M.; Matin, N.S.; Jalili, A.H.; Esfarayeni, M.H.; Khodagholi, M.A.; Ahmadi, R. Conversion of methane to methanol in an ac dielectric barrier discharge. Plasma Sources Sci. Technol. 2004, 13, 707-711. [CrossRef]

138. Larkin, D.W.; Lobban, L.L.; Mallinson, R.G. Production of Organic Oxygenates in the Partial Oxidation of Methane in a Silent Electric Discharge Reactor. Ind. Eng. Chem. Res. 2001, 40, 1594-1601. [CrossRef]

139. Indarto, A. A review of direct methane conversion to methanol by dielectric barrier discharge. IEEE Trans. Dielectr. Electr. Insul. 2008, 15, 1038-1043. [CrossRef]

140. Nozaki, T.; Ağıral, A.; Yuzawa, S.; Han Gardeniers, J.G.E.; Okazaki, K. A single step methane conversion into synthetic fuels using microplasma reactor. Chem. Eng. J. 2011, 166, 288-293. [CrossRef]

141. Nozaki, T.; Goujard, V.; Yuzawa, S.; Moriyama, S.; Agıral, A.; Okazaki, K. Selective conversion of methane to synthetic fuels using dielectric barrier discharge contacting liquid film. J. Phys. D Appl. Phys. 2011, 44, 274010. [CrossRef]

142. Nozaki, T.; Hattori, A.; Okazaki, K. Partial oxidation of methane using a microscale non-equilibrium plasma reactor. Catal. Today 2004, 98, 607-616. [CrossRef]

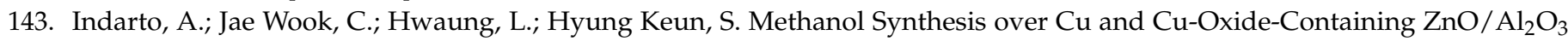
Using Dielectric Barrier Discharge. IEEE Trans. Plasma Sci. 2008, 36, 516-518. [CrossRef]

144. Zhang, Q.Z.; Bogaerts, A. Propagation of a plasma streamer in catalyst pores. Plasma Sources Sci. Technol. 2018, $27,035009$. [CrossRef]

145. Zhang, Q.Z.; Wang, W.; Bogaerts, A. Importance of surface charging during plasma streamer propagation in catalyst pores. Plasma Sources Sci. Technol. 2018, 27, 065009. [CrossRef]

146. Bogaerts, A.; Zhang, Q.Z.; Zhang, Y.-R.; Van Laer, K.; Wang, W. Burning questions of plasma catalysis: Answers by modeling. Catal. Today 2019, 337, 3-14. [CrossRef]

147. Van Laer, K.; Bogaerts, A. How bead size and dielectric constant affect the plasma behaviour in a packed bed plasma reactor: A modelling study. Plasma Sources Sci. Technol. 2017, 26, 085007. [CrossRef]

148. Wang, Y.; Craven, M.; Yu, X.; Ding, J.; Bryant, P.; Huang, J.; Tu, X. Plasma-Enhanced Catalytic Synthesis of Ammonia over a $\mathrm{Ni} / \mathrm{Al}_{2} \mathrm{O}_{3}$ Catalyst at Near-Room Temperature: Insights into the Importance of the Catalyst Surface on the Reaction Mechanism. ACS Catal. 2019, 9, 10780-10793.

149. De Bie, C.; Verheyde, B.; Martens, T.; Dijk, J.V.; Paulussen, S.; Bogaerts, A. Fluid Modeling of the Conversion of Methane into Higher Hydrocarbons in an Atmospheric Pressure Dielectric Barrier Discharge. Plasma Process. Polym. 2011, 8, $1033-1058$. [CrossRef]

150. De-Bie, C.; Dijk, J.V.; Bogaerts, A. The Dominant Pathways for the Conversion of Methane into Oxygenates and Syngas in an Atmospheric Pressure Dielectric Barrier Discharge. J. Phys. Chem. C 2015, 119, 22331-22350. [CrossRef]

151. Loenders, B.; Engelmann, Y.; Bogaerts, A. Plasma-catalytic partial oxidation of methane on Pt(111): A microkinetic study of the role of different plasma species. J. Phys. Chem. C 2021, 125, 2966-2983. [CrossRef] 
152. Takayuki Tsuchiya, S.I. Conversion of Methane to Methanol by a Low-Pressure Steam Plasma. J. Environ. Eng. Technol. 2013, 2, 35-39.

153. Pearce, M.P.; Bussemaker, M.J.; Cooper, P.D.; Lapere, K.M.; Wild, D.A.; McKinley, A.J. Formation of methanol from methane and water in an electrical discharge. Phys. Chem. Chem. Phys. 2012, 14, 3444-3449. [CrossRef] [PubMed]

154. Engelmann, Y.; Mehta, P.; Neyts, E.C.; Schneider, W.F.; Bogaerts, A. Predicted Influence of Plasma Activation on Non-Oxidative Coupling of Methane on Transition Metal Catalysts. ACS Sustain. Chem. Eng. 2020, 8, 6043-6054. [CrossRef]

155. Nozaki, T.; Okazaki, K. Non-thermal plasma catalysis of methane: Principles, energy efficiency, and applications. Catal. Today 2013, 211, 29-38. [CrossRef]

156. Yi, Y.; Wang, X.; Jafarzadeh, A.; Wang, L.; Liu, P.; He, B.; Yan, J.; Zhang, R.; Zhang, H.; Liu, X.; et al. Plasma-Catalytic Ammonia Reforming of Methane over Cu-Based Catalysts for the Production of $\mathrm{HCN}$ and $\mathrm{H}_{2}$ at Reduced Temperature. ACS Catal. 2021, 11, 1765-1773. [CrossRef] 